GUILHERME LUIZ SUSTERAS

\title{
APLICAÇÃO DE ALGORITMOS GENÉTICOS PARA PREVISÃO DO COMPORTAMENTO DAS DISTRIBUIDORAS COMO APOIO À ESTRATÉGIA DE COMERCIALIZAÇÃO DE ENERGIA DE AGENTES GERADORES
}

Dissertação apresentada à Escola Politécnica da Universidade de São Paulo para obtenção do título de Mestre em Engenharia Elétrica 
GUILHERME LUIZ SUSTERAS

\section{APLICAÇÃO DE ALGORITMOS GENÉTICOS PARA PREVISÃO DO COMPORTAMENTO DAS DISTRIBUIDORAS COMO APOIO À ESTRATÉGIA DE COMERCIALIZAÇÃO DE ENERGIA DE AGENTES GERADORES}

Dissertação apresentada à Escola Politécnica da Universidade de São Paulo para obtenção do título de Mestre em Engenharia Elétrica Área de Concentração: Sistemas de Potência Orientador: Prof. Dr. Dorel Soares Ramos

São Paulo 
Este exemplar foi revisado e alterado em relação à versão original, sob responsabilidade única do autor e com a anuência de seu orientador.

São Paulo, 23 de março de 2006.

Guilherme Luiz Susteras

Prof. Dr. Dorel Soares Ramos

FICHA CATALOGRÁFICA

Susteras, Guilherme Luiz

Aplicação de algoritmos genéticos para previsão do comportamento das distribuidoras como apoio à estratégia de comercialização de energia de agentes geradores / G.L. Susteras. -- ed.rev. -- São Paulo, 2006.

$101 \mathrm{p}$.

Dissertação (Mestrado) - Escola Politécnica da Universidade de São Paulo. Departamento de Engenharia de Energia e Automação Elétricas.

1.Energia elétrica 2.Geração de energia elétrica 3.Vendas (Planejamento) 4.Leilão 5.Algoritmos genéticos I.Universidade de São Paulo. Escola Politécnica. Departamento de Engenharia de Energia e Automação Elétricas Il.t. 


\section{FOLHA DE APROVAÇÃO}

Guilherme Luiz Susteras

Aplicação de Algoritmos Genéticos para previsão do comportamento das Distribuidoras como apoio à estratégia de comercialização de energia de Agentes Geradores

Dissertação apresentada à Escola Politécnica da Universidade de São Paulo para obtenção do título de Mestre em Engenharia Elétrica

Área de Concentração: Sistemas de Potência

Aprovado em:

Banca Examinadora

Prof. Dr. Dorel Soares Ramos

Instituição: PEA-EPUSP___ Assinatura:

Prof. Dr. José Aquiles Baesso Grimoni

Instituição: PEA-EPUSP

Assinatura:

Prof. Dr. Marciano Morozowski Filho

Instituição: UFSC Assinatura: 


\section{AGRADECIMENTOS}

Agradeço a Deus pela saúde e força necessárias para executar meu trabalho.

Agradeço ao meu orientador, prof. Dorel, por sua atenção e por suas fundamentais contribuições para o andamento do trabalho, bem como aos professores da banca do exame de qualificação, professores Aquiles, Lineu e Tahan, pelas importantes considerações.

Agradeço aos meus amigos e colegas da Duke Energy, em especial ao meu gerente Carlos Dornellas, pelos incentivos, contribuições e apoio durante toda a execução do meu mestrado.

Agradeço aos meus pais e meus irmãos, pelo suporte emocional e incentivo ao meu trabalho.

Agradeço à Alexandra, minha namorada, pela paciência e pelas incontáveis revisões. 


\section{RESUMO}

SUSTERAS, G. L. Aplicação de Algoritmos Genéticos para previsão do comportamento das Distribuidoras como apoio à estratégia de comercialização de energia de Agentes Geradores. 2006. 101 f. Dissertação (Mestrado) - Escola Politécnica, Universidade de São Paulo, São Paulo, 2006.

As regras definidas pelo Decreto 5.163/2004 trazem incentivos e penalidades aos Distribuidores no processo de apresentação de suas declarações de necessidades de compra de energia ao Ministério de Minas e Energia. Nesse sentido, é importante para os Geradores estabelecer uma metodologia robusta para prever o comportamento dos agentes de distribuição com confiabilidade razoável, de forma a permitir uma preparação adequada para os leilões de que pretendem participar e, adicionalmente, simular os cenários pós-leilões de modo a compreender os efeitos dos preços e volumes contratados no ambiente regulado sobre as condições de contratação no ambiente livre. Este trabalho propõe-se a analisar as referidas regras, apresentando um modelo de otimização utilizando Algoritmos Genéticos que simula o comportamento das distribuidoras, obtendo-se uma importante ferramenta de apoio à definição de estratégias de comercialização de uma empresa geradora.

Palavras-chave: Algoritmos Genéticos, Contratação de Energia, Estratégias de Comercialização de Energia, Otimização, Setor Elétrico Brasileiro. 


\begin{abstract}
SUSTERAS, G. L. Applying Genetic Algorithms for predicting Distribution companies behavior to support Generation companies' power selling strategy. 2006. 101 f. Dissertation (Master’s degree) - Escola Politécnica, Universidade de São Paulo, São Paulo, 2006.

The rules defined by the Decree 5.163/2004 bring incentives and penalties for Distribution companies to present their power purchase necessity declaration for the Ministry of Mines and Energy. In this sense, it is important for the Generation companies to establish a robust methodology for predicting Distribution companies behavior with enough accountability in order to allow an adequate preparation for the auctions in which those agents intend to participate and, additionally, simulate post auctions scenarios in order to understand the effects of prices and contracted volumes in the regulated environment over the free market contracting conditions. This work is supposed to analyze those rules, presenting an optimization model using Genetic Algorithms, which simulates Distribution companies behavior, getting an important power trading strategy decision support tool for a Generation Company.
\end{abstract}

Key-words: Genetic Algorithms, Energy Contracting, Power Trading Strategy, Brazilian Power Sector. 


\section{LISTA DE FIGURAS}

Figura 2.1 - Equivalência entre as relações contratuais e comerciais ....................... 16

Figura 2.2 - Linha do tempo dos modelos ........................................................... 23

Figura 3.1 - Visão geral das relações contratuais ................................................... 27

Figura 3.2 - Opções de contratação das distribuidoras ............................................... 33

Figura 3.3 - Balanço ilustrativo de energia assegurada .......................................... 41

Figura 3.4 - Convivência entre mercado competitivo e regulado ............................ 46

Figura 4.1 - Exemplo de indivíduo modelado para Algoritmos Genéticos ................57

Figura 4.2 - Algoritmo genético básico ............................................................... 57

Figura 4.3 - Algoritmo de escalamento linear........................................................5

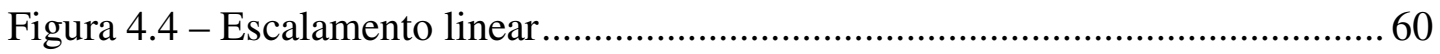

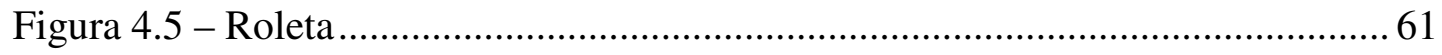

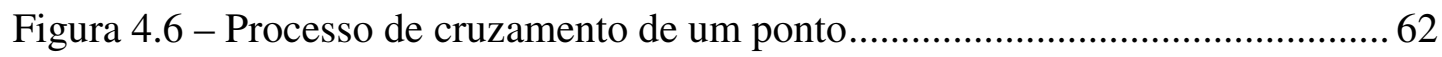

Figura 4.7 - Processo de cruzamento de dois pontos............................................... 62

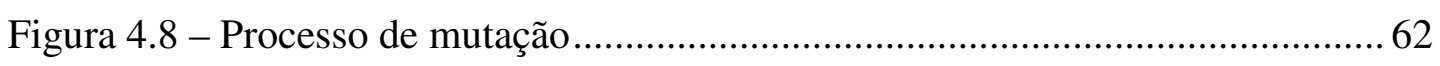

Figura 4.9 - Exemplo de codificação binária de problema....................................... 63

Figura 4.10 - Regra de formação do binário Gray..................................................... 64

Figura 5.1 - Entrada dos preços do modelo .......................................................... 67

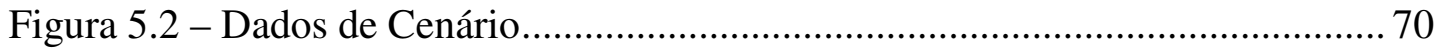

Figura 5.3 - Tela de entrada para definição dos leilões a serem considerados.......... 72

Figura 5.4 - Tela de entrada dos parâmetros definidos em Decreto........................... 72

Figura 5.5 - Algoritmo genético esquematizado .................................................. 73

Figura 5.6 - Vetor representando o indivíduo na otimização ................................... 75

Figura 5.7 - Perfil de contratação da COPEL........................................................... 78

Figura 5.8 - Entrada de parâmetros numéricos no modelo para o caso COPEL ....... 79

Figura 5.9 - Entrada de parâmetros de execução para o caso COPEL ....................... 79

Figura 5.10 - Entrada de parâmetros do mercado no modelo para o caso COPEL... 80

Figura 5.11 - Contratação no mega-leilão proposta para o caso COPEL................... 80

Figura 5.12 - Perfil de contratação proposto pelo modelo para o caso COPEL......... 81

Figura 5.13 - Evolução das gerações para o caso COPEL ....................................... 83

Figura 5.14 - Zoom na evolução das últimas 250 gerações para o caso COPEL...... 83 
Figura 5.15 - Contratação no mega-leilão proposta pelo modelo após alteração da

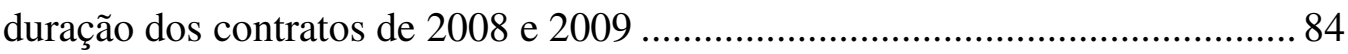

Figura 5.16 - Resultado da calibração do modelo .................................................. 85

Figura 5.17 - Vetor representando o indivíduo na otimização, com redução do

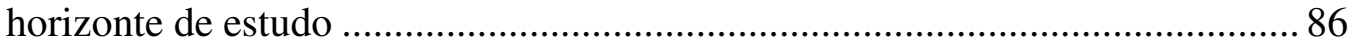

Figura 5.18 - Resultado do modelo com horizonte reduzido .................................... 86

Figura 5.19 -Resultado do modelo com horizonte reduzido e pequenas alterações nos

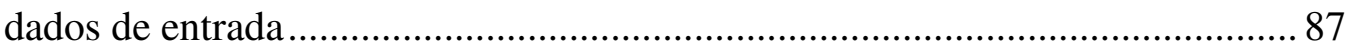

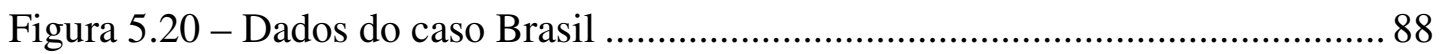

Figura 5.21 - Comparação entre simulado e real para o caso Brasil ......................... 89

Figura 5.22 - Perfil de contratação completo do caso Brasil..................................... 89

Figura 5.23 - Evolução das espécies no caso Brasil ................................................. 90

Figura 5.24 - Evolução das espécies, com zoom nas últimas 250 gerações, para o

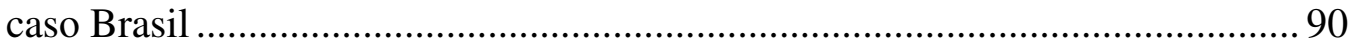

Figura 5.25 - Análise do incentivo à contratação da totalidade da carga ................... 91

Figura 5.26 - Avaliação dos incentivos para contratação de energia nova ............... 92

Figura 5.27 - Análise da opção de redução dos contratos de energia existente ........ 93 


\section{LISTA DE TABELAS}

Tabela 3.1 - Exemplo de dois agentes hipotéticos ................................................ 44

Tabela 4.1 - Diferença entre codificação binária convencional e a Gray................... 64

Tabela 5.1 - Matriz ilustrativa da influência do PLD e do CME ............................. 68

Tabela 5.2 - Síntese das variáveis do modelo......................................................... 76

Tabela 5.3 - Possíveis parâmetros para o Algoritmo Genético ................................ 77

Tabela 5.4 - Volumes do mega-leilão relativos à COPEL ........................................ 82

Tabela 5.5 - Comparação dos resultados do modelo com dados da COPEL ............ 82 


\section{LISTA DE SIGLAS}

ABRADEE Associação Brasileira das Distribuidoras de Energia Elétrica

ABRAGE Associação Brasileira dos Grandes Geradores de Energia Elétrica

ABRAGEF Associação Brasileira de Geração Flexível

ABRAGET Associação Brasileira de Geradoras Termelétricas

ACL Ambiente de Contratação Livre

ACR Ambiente de Contratação Regulada

ANA Agência Nacional de Águas

ANEEL Agência Nacional de Energia Elétrica

APINE Associação Brasileira dos Produtores Independentes de Energia Elétrica

APMPE Associação Brasileira dos Pequenos e Médios Produtores de Energia Elétrica

CCEAR Contrato de Comercialização de Energia no Ambiente Regulado

CCEE Câmara de Comercialização de Energia Elétrica

CEPEL Centro de Pesquisas de Energia Elétrica

CME Custo Marginal de Expansão

CPST Contrato de Prestação de Serviço de Transmissão

CUST Contrato de Uso do Sistema de Transmissão

EPE Empresa de Pesquisa Energética

GCE Câmara de Gestão da Crise de Energia Elétrica

IBAMA Instituto Brasileiro do Meio Ambiente e dos Recursos Naturais Renováveis

MAE Mercado Atacadista de Energia

MME Ministério de Minas e Energia

ONS Operador Nacional do Sistema Elétrico

PIE Produtor Independente de Energia

Re-seb Projeto de Reestruturação do Setor Elétrico Brasileiro

SIN Sistema Interligado Nacional 


\section{SUMÁRIO}

1. INTRODUÇÃ

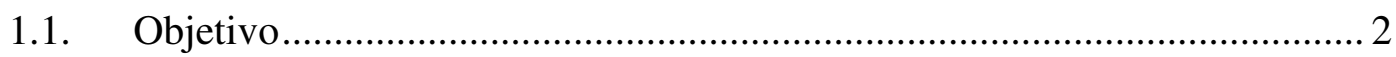

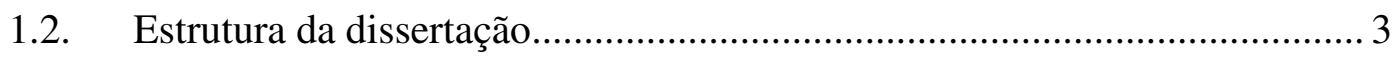

2. A EVOLUÇÃO DO MODELO DO SETOR ELÉTRICO ............................... 4

2.1. Visão Geral do Setor Elétrico .................................................................. 4

2.2. A reforma do setor elétrico ................................................................ 5

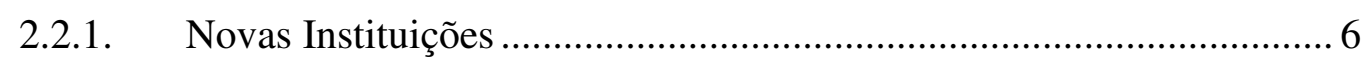

2.2.2. O Racionamento de Energia Elétrica ............................................... 9

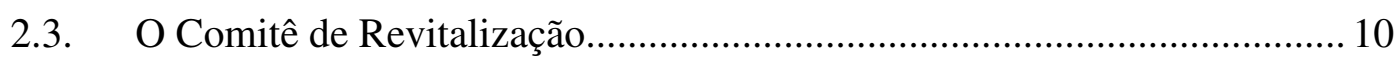

2.3.1. Referência à "Energia Velha" ......................................................... 13

2.4. A eleição presidencial de 2002 ............................................................... 13

2.5. A primeira proposta oficial de modelo ................................................... 14

2.5.1. As relações contratuais na primeira proposta de modelo................... 15

2.5.2. As relações comerciais na primeira proposta do modelo.................... 16

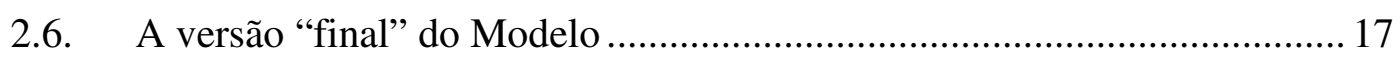

2.6.1. Premissas do Modelo ...................................................................... 17

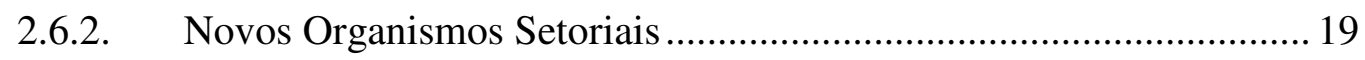

2.6.2.1. Empresa de Pesquisa Energética - EPE................................... 19

2.6.2.2. Câmara de Comercialização de Energia Elétrica - CCEE......... 20

2.6.2.3. Comitê de Monitoramento do Setor Elétrico - CMSE .............. 20

2.6.2.4. Adaptações às atribuições das instituições já existentes ............ 21

2.6.3. Sumário das principais alterações introduzidas pelo Modelo e suas

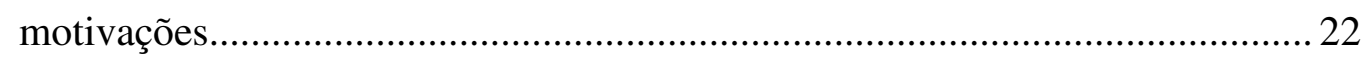

3. RELAÇÕES CONTRATUAIS E COMERCIAIS NO MODELO DO SETOR

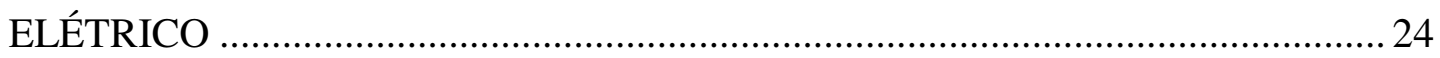

3.1. A natureza do contrato de compra e venda de energia elétrica.................. 24

3.1.1. Características de um contrato de energia........................................ 24

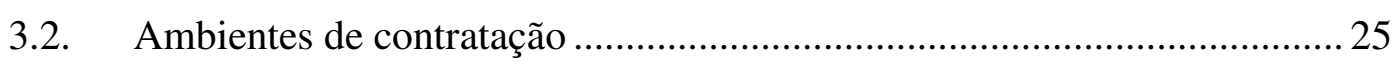

3.2.1. O Ambiente de Contratação Regulada .............................................. 26

3.2.2. O Ambiente de Contratação Livre .................................................... 26 
3.2.3. O mercado de curto prazo ........................................................... 27

3.3. A regulamentação das relações contratuais e comerciais ......................... 28

3.3.1. Regras Gerais de Comercialização................................................... 29

3.3.2. Comercialização no ACR ……....................................................... 30

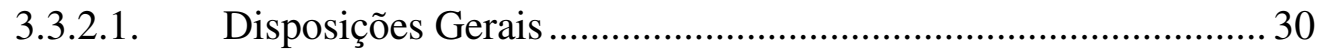

3.3.2.2. Declarações de Necessidades ................................................. 31

3.3.2.3. Leilões para Compra de Energia Elétrica.................................. 32

3.3.2.4. Contratos de Compra e Venda de Energia ................................ 35

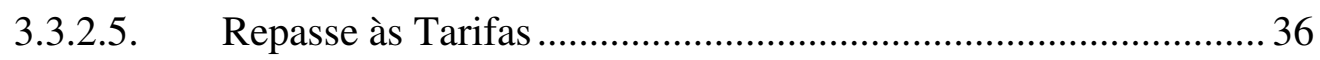

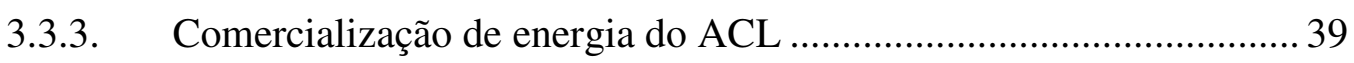

3.3.3.1. Fontes adicionais de receita para os geradores ........................ 40

3.3.4. Mercado de Curto Prazo................................................................... 40

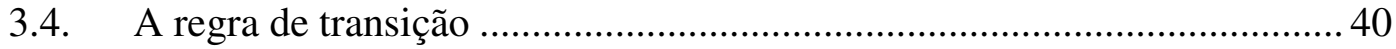

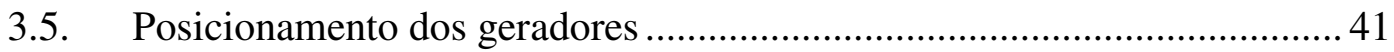

3.5.1. Definição de estratégia de comercialização de energia...................... 42

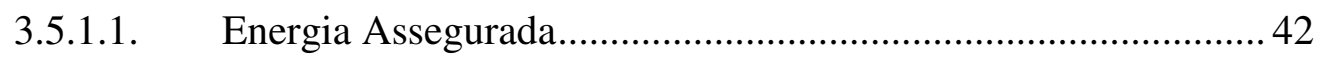

3.5.1.2. Mecanismo de Realocação de Energia - MRE .......................... 43

3.5.2. O montante de energia a ser comercializado................................... 44

3.5.3. Aspectos a serem considerados na elaboração da estratégia.............. 45

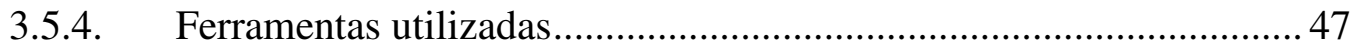

3.6. Contratação das Distribuidoras: função objetivo a ser otimizada.............. 48

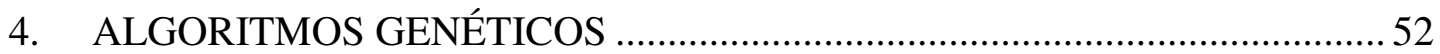

4.1. Introdução a métodos de otimização.....................................................52

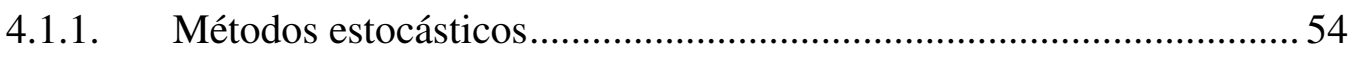

4.1.1.1. Métodos naturais ....................................................................... 54

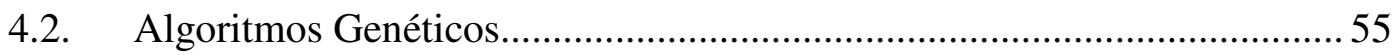

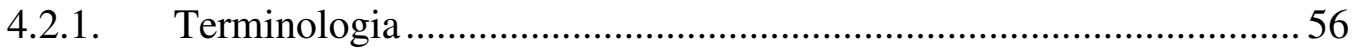

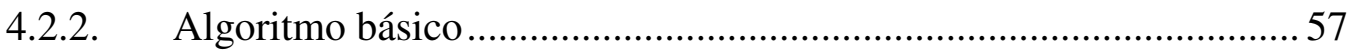

4.2.3. Passos para implementação de um AG ……...................................... 63

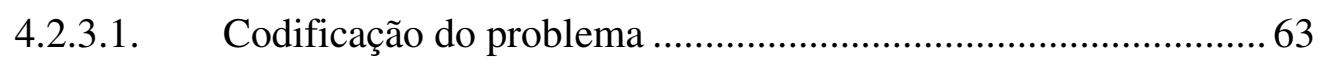

4.2.3.2. Definição da função de avaliação ............................................. 65

4.2.3.3. Definição dos parâmetros do AG .............................................. 65 


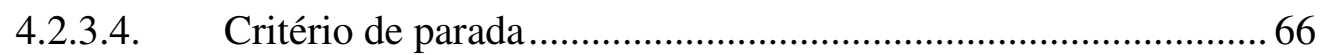

5. MODELO DE OTIMIZAÇÃO DA CONTRATAÇÃO DAS

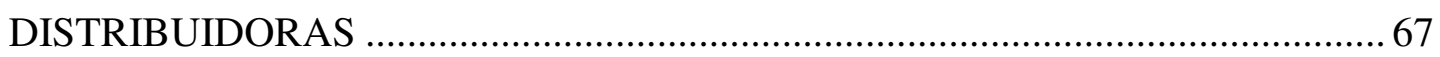

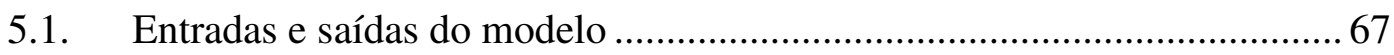

5.2. Parâmetros e características de desempenho............................................ 74

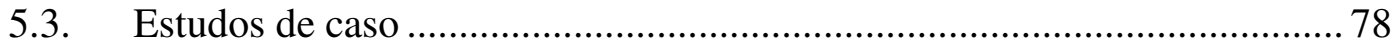

5.3.1. Distribuidora típica - aferição do modelo......................................... 78

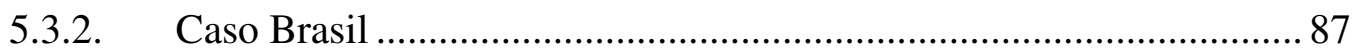

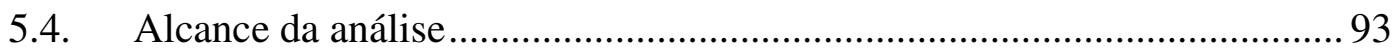

6. CONCLUSÕES E RECOMENDAÇÕES ..................................................... 95

6.1. Com relação ao Modelo Institucional do Setor Elétrico ............................. 95

6.2. Com relação ao modelo de otimização desenvolvido ................................. 96

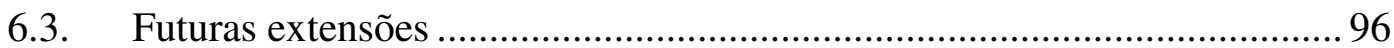

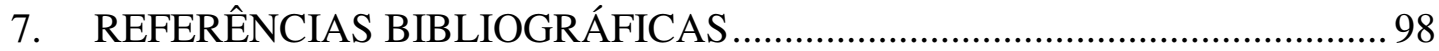




\section{INTRODUÇÃO}

O setor elétrico representa uma das mais importantes peças da economia nacional. É impossível imaginar-se uma economia próspera sem investimentos em energia, especialmente a eletricidade, essencial para disponibilizar força motriz para a indústria, comércio e serviços; trata-se de um insumo básico.

O sistema elétrico brasileiro apresenta como particularidade grandes extensões de linhas de transmissão e um parque produtor de geração predominantemente hidrelétrica. O mercado consumidor (mais de 47 milhões de unidades) concentra-se nas regiões Sul e Sudeste, mais industrializadas, que fazem parte do Sistema Interligado Nacional - SIN. Na região Norte há sistemas isolados atendidos de forma intensiva por pequenas centrais geradoras, a maioria termelétricas a óleo diesel.

Ao longo das últimas duas décadas, o consumo de energia elétrica apresentou índices de expansão bem superiores ao Produto Interno Bruto (PIB), fruto do crescimento populacional concentrado nas zonas urbanas, do esforço de aumento da oferta de energia e da modernização da economia [ANEEL, 2004].

O Modelo Institucional do Setor Elétrico Brasileiro, instituído pelo governo do presidente Luiz Inácio Lula da Silva, propõe uma série de mudanças estruturais, em busca de aprimoramentos necessários a este tão essencial setor da economia.

Uma das mudanças mais inovadoras, dado que não se tem notícia de qualquer outro mercado, em âmbito mundial, em que se tenha aplicado tal proposta, é a segregação da energia em "velha" e "nova". Esta criação traz consigo um grande desafio para as empresas do setor, especialmente aquelas que passaram por um processo de privatização no final da década de 1990 e que tiveram seus investimentos renovados, qual seja comercializar sua energia, considerada "velha" no modelo em implantação e concorrer com empresas estatais, cujas plantas já têm maior tempo de depreciação e cuja função objetivo nos leilões do Pool é desconhecida. A questão a ser respondida é: estas empresas tentarão maximizar seu lucro ou viabilizar a tão 
propagada modicidade tarifária? Vale ressaltar a grande participação das concessionárias de serviço público de geração no mercado - só a Eletrobrás, através de suas subsidiárias, detém quase $60 \%$ da energia elétrica produzida no país.

\subsection{Objetivo}

Este trabalho, sem pretensão de apresentar soluções definitivas, propõe-se a estudar a situação e desenvolver um modelo de apoio à formulação de estratégias de comercialização da chamada "energia velha" de uma empresa geradora detentora de usinas hidrelétricas adquiridas em leilão de privatização.

Neste ambiente setorial, as opções de contratação de uma geradora são o Ambiente de Contratação Regulada (ACR), o Ambiente de Contratação Livre (ACL) e o mercado de diferenças (Spot). O mercado regulado é aquele no qual participam obrigatoriamente as distribuidoras de energia elétrica. Como o ACR acomoda os maiores volumes de energia e preços de venda mais atrativos, é natural que o principal mercado para os geradores seja o regulado.

Para que se possa desenhar uma boa estratégia de comercialização de energia existente, é importante se conhecer o mercado que se pretende atingir. Para tanto, o modelo desenvolvido tenta prever o comportamento das distribuidoras através da otimização de contratação nos diversos leilões existentes ("mega-leilão" de transição, A-5, A-3, A-1, ajuste), seguindo os incentivos e penalidades previstas na legislação vigente, notadamente no decreto 5.163/04.

A função objetivo a ser maximizada no processo de otimização de contratação é o valor presente dos lucros e prejuízos para a distribuidora advindos dos citados incentivos e penalidades. As variáveis de decisão são os volumes a serem contratados em cada leilão disponível, bem como o percentual de redução dos contratos de energia existente a que as distribuidoras têm direito, conforme definido nos regulamentos. 
Dada a natureza não linear, não convexa e com ingredientes estratégicos do problema, o modelo foi desenvolvido utilizando algoritmo genético, com horizonte de estudo até 2011.

\subsection{Estrutura da dissertação}

No capítulo 2 se faz uma rápida incursão pela história recente do Setor Elétrico, iniciando-se pelas reformas propostas no âmbito do projeto Re-seb na tentativa de implementar um modelo de mercado chegando até o modelo em implantação.

O capítulo 3 apresenta as relações contratuais, comerciais e demais características do modelo em implantação, detalhando os pontos mais importantes da regulamentação para o estudo em tela.

No capítulo seguinte, introduz-se a teoria envolvida com o método de solução escolhido - algoritmos genéticos.

No capítulo 5 é apresentado o modelo de otimização proposto com suas variáveis de entrada e saída, suas características de desempenho, bem como são feitos dois estudos de caso: um deles considerando uma distribuidora típica, comparando os resultados com aqueles informados ao MME, de modo a validar o modelo e, o outro, considerando uma distribuidora fictícia agregando todo o mercado brasileiro e que, de fato, guiará a tomada de decisões por parte da empresa geradora.

Finalmente, o capítulo 6 apresenta as conclusões e recomendações do trabalho, verificando a eficácia dos incentivos contidos na regulamentação, isto é, se as distribuidoras são levadas a tomarem decisões conforme a expectativa do MME. 


\section{A EVOLUÇÃO DO MODELO DO SETOR ELÉTRICO}

\subsection{Visão Geral do Setor Elétrico}

As atividades do setor elétrico podem ser agrupadas em quatro segmentos principais:

1. geração

2. transmissão

3. distribuição

4. comercialização

O segmento de geração abrange todas as atividades de produção de energia (usinas hidrelétricas, térmicas e outras fontes alternativas), incluindo a importação de países de fronteira, exercidas atualmente por Concessionários de Serviço Público de Geração e por Produtores Independentes de Energia - PIEs, que podem ser subdividas em dois grupos principais:

- Operação - inclui tudo o que for relacionado com o atendimento da demanda a cada instante, utilizando os recursos de geração disponíveis.

- Expansão - abrange as decisões de investimento em nova capacidade, com o objetivo de assegurar o atendimento futuro da demanda.

O segmento de transmissão se refere às atividades de transporte da energia produzida até os grandes centros de consumo. Assim como o segmento de geração, as atividades de transmissão podem ser subdivididas em operação e expansão.

O terceiro segmento, distribuição, se encarrega do transporte final da energia a partir dos pontos de entrega na rede de alta tensão até os consumidores finais.

O último segmento, comercialização de energia, está encarregado das atividades de contratação da geração e revenda aos consumidores. 


\subsection{A reforma do setor elétrico}

Antes da reforma iniciada em meados da década de 1990, praticamente todos os segmentos do setor elétrico eram de propriedade pública (federal e estadual, no caso de geração e transmissão; estadual e municipal, no caso de distribuição e comercialização), sendo que apenas $0,1 \%$ dos ativos de geração e/ou distribuição eram explorados por pequenas empresas privadas de âmbito municipal e regional. Este processo de reforma institucional teve os seguintes objetivos básicos:

- Assegurar os investimentos necessários para a expansão da oferta de energia, uma vez que havia uma percepção de esgotamento da capacidade do Estado de investir em infra-estrutura na escala necessária para atender ao aumento da demanda; e

- Assegurar que o setor fosse economicamente eficiente, utilizando os recursos disponíveis para garantir um suprimento confiável de energia elétrica ao menor custo possível.

Para atingir estes objetivos, foram adotados dois princípios básicos, semelhantes aos que orientaram o processo de reforma em outros países:

- Estabelecimento de competição nos segmentos de geração e comercialização para consumidores livres, com o objetivo de estimular o aumento da eficiência e redução dos preços;

- Estabelecimento de monopólios regulados nas atividades de transmissão, distribuição e comercialização para consumidores cativos (no caso das redes, trata-se de monopólios naturais, e no caso dos pequenos consumidores, entendia-se que, no momento, não existiam condições de natureza prática para definir tais consumidores como elegíveis ao mercado livre).

A coexistência de setores regulados e competitivos foi (e ainda é) um dos principais desafios na implementação de reformas no setor elétrico. Seu equacionamento requer a adoção das seguintes medidas: 
- Regulação por incentivos dos segmentos de monopólio natural, através de ações que estimulem a eficiência e modicidade dos preços dos segmentos regulados.

- Defesa da concorrência, por meio da regulação de conduta e da estrutura.

A primeira visa a promover o livre acesso às redes de transmissão e distribuição, de forma a permitir efetivamente a competição na geração e comercialização e a segunda, coibir o exercício de poder de mercado. A garantia de livre acesso em geral requer a desverticalização, ou seja, separação entre as atividades de geração, transmissão e comercialização (à exceção do segmento regulado de transmissão, que não deveria ter qualquer outra atividade, muitos países aceitam que geradoras e distribuidoras exerçam atividades de comercialização, em competição com as comercializadoras independentes).

No modelo brasileiro, para contornar as dificuldades políticas que se prenunciaram ao iniciar a discussão para desverticalizar as grandes geradoras federais, adotou-se uma alternativa que permitia a empresa integrada Geração e Transmissão, porém com o planejamento da expansão da transmissão e a operação de redes sendo atividades exercidas de forma centralizada.

Finalmente, o modelo regulatório foi construído dentro de uma perspectiva de privatização generalizada da geração e da distribuição, com exceção das geradoras nucleares (parcela relativamente pequena do sistema) e Itaipu. A principal motivação técnica para a privatização foi a separação entre atividades empresariais e atividades típicas de governo, equalizando as condições de atuação dos agentes no mercado competitivo.

\subsubsection{Novas Instituições}

A reforma do Setor provocou o surgimento de novas funções e modificou o conteúdo e a forma de outras atividades, como por exemplo, a regulamentação. Isto tornou necessária a criação de novas entidades. 
Dentre estas, são especialmente relevantes para o dia-a-dia das empresas do Setor:

- Agência Nacional de Energia Elétrica - ANEEL é o órgão regulador e fiscalizador do Setor Elétrico. Além das suas competências básicas, à ANEEL foi atribuído, por delegação da União, o papel de Poder Concedente. Suas atribuições incluíam, dentre outras, "promover as licitações destinadas à contratação de concessionárias de serviço público para geração, transmissão e distribuição de energia elétrica e para a outorga de concessão para aproveitamento de potenciais hidráulicos"; "celebrar e gerir os contratos de concessão ou de permissão de serviços públicos de energia elétrica, de concessão de uso de bem público, expedir as autorizações, bem como fiscalizá-los"; além de "regular as tarifas e estabelecer as condições gerais de contratação do acesso e uso dos sistemas de transmissão e de distribuição de energia elétrica por concessionário, permissionário e autorizado, bem como pelos consumidores livres". Finalmente, cabia à ANEEL definir as regras de participação no MAE (Mercado Atacadista de Energia Elétrica - ver adiante), homologar o Acordo de Mercado e autorizar as atividades do ONS ${ }^{1}$.

- Mercado Atacadista de Energia Elétrica - MAE foi definido como o ambiente onde se realizariam as transações de compra e venda de energia elétrica no Sistema Interligado Brasileiro, incluindo as atividades de contabilização destas transações e liquidação das diferenças verificadas entre os valores contratados e verificados por medição. O MAE era regido por uma Assembléia Geral, composta por representantes de Produção e Consumo, e por um comitê executivo denominado COMAE, cujos membros com direito a voto eram escolhidos pelos agentes de Produção, de Consumo e pela ANEEL. Cabia à ANEEL homologar quaisquer

\footnotetext{
${ }^{1}$ As atribuições da ANEEL foram alteradas pela lei 10.848, que instituiu o Modelo do Setor Elétrico Brasileiro. As alterações serão oportunamente tratadas adiante.
} 
decisões ou alterações das Regras de Mercado que viessem a ser aprovadas pela Assembléia Geral ${ }^{2}$.

- Operador Nacional do Sistema Elétrico - ONS foi instituído como personalidade jurídica de direito privado, tendo como principais atribuições: o planejamento e a programação da operação; o despacho centralizado da geração; a contratação e administração de serviços de transmissão de energia elétrica; e a proposição de ampliações/reforços das instalações de transmissão da rede básica no horizonte de curto prazo. $\mathrm{O}$ ONS atua mediante autorização e fiscalização da ANEEL.

- Comitê Coordenador do Planejamento da Expansão - CCPE $E^{3}$ - estava estabelecido no âmbito do Ministério de Minas e Energia, tendo como objetivos principais:

1. Orientar as ações de governo para assegurar o fornecimento de energia elétrica nos padrões de qualidade e quantidade demandados pela sociedade, em conformidade com a Política Energética Nacional definida pelo Conselho Nacional de Política Energética - CNPE;

2. Oferecer aos agentes do mercado de energia um quadro de referência para seus planos de investimentos (planejamento indicativo); e

3. Estabelecer a expansão mais adequada da rede de transmissão, em consonância com os aspectos operacionais do sistema (de acordo com o protocolo vigente MME/ONS, este último agente está encarregado do Plano de Ampliações e Reforços, no horizonte de três anos) [Comitê de Revitalização do Modelo do Setor Elétrico, 2002b].

\footnotetext{
2 Também pela lei 10.848 o MAE sofreu alterações, passando a se chamar CCEE - Câmara de Comercialização de Energia Elétrica. Maiores detalhes serão apresentados adiante.

${ }^{3}$ O CCPE foi extinto no Modelo atual, tendo suas funções assumidas pela EPE - Empresa de Pesquisa Energética, criada pela lei 10.847/2004 e que será descrita com mais detalhes adiante.
} 


\subsubsection{O Racionamento de Energia Elétrica}

A Câmara de Gestão da Crise de Energia Elétrica (GCE) foi criada pelo Presidente Fernando Henrique Cardoso, por meio de Medida Provisória, no dia 10 de maio de 2001, com a finalidade de administrar um período que se antevia extremamente crítico no que diz respeito ao suprimento de energia elétrica nas Regiões Sudeste/Centro-Oeste e Nordeste.

O programa de racionamento vigorou no período de $1^{\circ}$ de junho de 2001 até 28 de fevereiro de 2002, nas regiões Sudeste/Centro-Oeste e Nordeste. Na Região Norte, o racionamento terminou no dia $1^{\circ}$ de janeiro de 2002 , tendo começado no dia 15 de agosto de 2001 para os grandes consumidores e no dia 20 de agosto para os demais consumidores.

As causas que levaram o País àquela conjuntura adversa foram exaustivamente apontadas e debatidas desde então, entre estas a sucessão de alguns anos de baixa precipitação pluviométrica, levando ao progressivo esvaziamento dos reservatórios das usinas hidrelétricas [Energia Brasil, 2002] e a falta de investimentos em geração e transmissão [Sauer, 2002].

A GCE foi instalada no âmbito da Presidência da República e lhe foram atribuídos poderes extraordinários, inclusive o de tomar decisões imediatas, em caráter de última instância, sobre temas cuja competência pertence ao Poder Executivo.

Por determinação do Presidente da República, o programa de racionamento deveria atender a dois princípios:

a) cada consumidor deveria ter o direito de decidir quando e como cumpriria suas metas - o recurso aos "apagões" deveria ser uma medida de última instância;

b) mecanismos especiais deveriam ser criados para atenuar a crise no setor produtivo, para que a produção e o emprego não fossem prejudicados além do estritamente necessário. 
O programa de racionamento não foi a única providência adotada. Outras cinco linhas de ação foram definidas:

a) Programa Estrutural de Aumento da Oferta de Energia;

b) Programa Emergencial de Aumento da Oferta de Energia;

c) Programa de Conservação e Uso Eficiente de Energia;

d) Revitalização do Modelo do Setor Elétrico

e) Medidas para Atenuar os Efeitos Econômicos e Sociais do Racionamento.

Superando as estimativas mais otimistas, a adesão das famílias, das empresas e das demais instituições foi surpreendente. No primeiro mês do racionamento - em que, na prática, não houve cobrança das metas - o programa já atingia seus objetivos.

A sociedade pôde acompanhar a evolução do programa graças à avaliação pública permanente da curva guia de segurança estabelecida pelo Operador Nacional do Sistema (ONS). A curva guia representava o nível mínimo de abastecimento dos reservatórios de água para que as usinas hidrelétricas fossem capazes de atender à demanda durante todo o período seco. Acima da curva guia, foi traçada uma segunda curva indicando o comportamento real dos reservatórios e os ganhos essenciais obtidos com o racionamento.

No dia 19 de fevereiro de 2002, durante reunião plenária da GCE, na presença do Presidente Fernando Henrique Cardoso, dados apresentados pelo Operador Nacional do Sistema (ONS) mostravam que os reservatórios haviam atingido um nível satisfatório, suficiente para permitir ao Governo deliberar sobre a suspensão do racionamento. Assim, foi decidido que o programa de racionamento seria encerrado no dia 28 de fevereiro de 2002 [Energia Brasil, 2002].

\subsection{O Comitê de Revitalização}

O Comitê de Revitalização do Modelo do Setor Elétrico foi criado em junho de 2001, pela Resolução 18 da Câmara de Gestão da Crise de Energia, com a missão de 
corrigir disfuncionalidades e propor aperfeiçoamentos que favorecessem a expansão da oferta de energia elétrica. A instalação do Comitê ocorreu em 27/06/2001.

O trabalho de revitalização foi realizado com base no princípio que determinava a preservação dos pilares do então novo modelo brasileiro do setor energético: competição nos segmentos de geração e comercialização de energia elétrica, expansão dos investimentos necessários com base em aportes do setor privado e regulação dos segmentos que são monopólios naturais - transmissão e distribuição de energia elétrica - para garantir a qualidade dos serviços e o suprimento de energia elétrica de forma compatível com as necessidades de desenvolvimento do país.

Ao longo de mais de cinco meses de atuação, foram realizadas 25 reuniões plenárias do Comitê, além de reuniões com os agentes públicos e privados do setor - Abrage (Associação Brasileira das Empresas Geradoras de Energia Elétrica), Abradee (Associação Brasileira das Distribuidoras de Energia Elétrica), Abraceel (Associação Brasileira dos Agentes Comercializadores de Energia Elétrica), ABCE (Associação Brasileira das Concessionárias de Energia Elétrica), Comae (Comitê Executivo do MAE), empresas do setor, empresas de consultoria e com técnicos do Banco Mundial para melhor identificação dos problemas existentes.

Uma das principais atividades do Comitê foi a realização do acordo geral do setor, concretizado em dezembro de 2001. Esse acordo permitiu a solução definitiva das controvérsias regulatórias e contratuais entre os agentes, estabeleceu as regras para o futuro, a recomposição tarifária extraordinária e o financiamento do BNDES ao setor de modo a evitar um choque tarifário [Energia Brasil, 2002].

O Comitê de Revitalização chegou a 33 temas para o aperfeiçoamento do Modelo Institucional:

1. Aperfeiçoamento do despacho e formação de preço

2. Implementação de oferta de preços

3. Regulamentação da Comercialização da Energia de Serviço Público

4. Fontes alternativas de energia 
5. Universalização do atendimento

6. Continuação da reestruturação do MAE

7. Desverticalização

8. Reestruturação do MME

9. Reforço do sinal locacional nas tarifas de transmissão

10. Governança do ONS

11. Revisão dos certificados de energia assegurada

12. Estímulo à contratação bilateral

13. Estímulo à contratação de reserva de geração

14. Mudanças no valor normativo (VN)

15. Subsídio ao gás natural

16. Estímulo à existência de consumidores livres

17. Eliminação dos subsídios cruzados

18. Limites para autocontratação e participação cruzada

19. Aperfeiçoamento dos procedimentos de rede do ONS

20. Finalização e aperfeiçoamento dos modelos computacionais utilizados pelo ONS

21. Procedimentos de alerta quanto a dificuldades de suprimento

22. Supervisão por parte do MME das condições de atendimento

23. Estímulo à expansão da capacidade de suprimento de ponta

24. Aperfeiçoamento das metodologias para expansão da rede de transmissão

25. Estímulo à conservação e uso racional da energia

26. Aperfeiçoamento das regras do MAE

27. Aperfeiçoamento do processo de definição de submercados

28. Aperfeiçoamento das regras do Mecanismo de Realocação de Energia (MRE)

29. Separação das componentes de comercialização e rede nas tarifas de distribuição

30. Aperfeiçoamento e definições nas revisões tarifárias das distribuidoras

31. Agilização do processo de licenciamento ambiental

32. Tarifa social de baixa renda

33. Regularização dos contratos de concessão 


\subsubsection{Referência à "Energia Velha"}

O tema 3 "Regulamentação da Comercialização da Energia de Serviço Público" tratou da venda da chamada "energia velha" das geradoras de serviço público à medida que fosse liberada dos Contratos Iniciais [Comitê de Revitalização do Modelo do Setor Elétrico, 2002a].

A proposta indicava que a energia proveniente das empresas de geração de serviço público sob controle federal e estadual, com exceção de Itaipu e Eletronuclear, deveria ser comercializada da seguinte forma:

1. As empresas geradoras de propriedade federal e estadual promoveriam leilões públicos regulados pela ANEEL de contratos de suprimento de energia, correspondentes à energia que fosse progressivamente liberada com a redução dos Contratos Iniciais e à energia não contratada que já tivesse entrado ou que entraria no sistema como, por exemplo, Tucuruí II.

2. No caso da energia liberada dos Contratos Iniciais, previa-se um preço mínimo para os leilões que corresponderia à tarifa destes contratos. No caso da energia não contratada que entrasse no sistema, este preço mínimo seria estabelecido em função de parâmetros associados a cada caso.

3. Os participantes deste leilão seriam as distribuidoras, comercializadoras e consumidores livres. O montante e duração dos contratos seriam definidos pelas empresas geradoras, embora a duração pudesse ficar condicionada a prazos mínimos e máximos estabelecidos em regulamentação. Previa-se uma duração variando de três a dez anos, ajustada de maneira a evitar que grandes montantes de energia tivessem seus contratos encerrados simultaneamente [Comitê de Revitalização do Modelo do Setor Elétrico, 2002].

\subsection{A eleição presidencial de 2002}

Desde a campanha presidencial para as eleições de 2002, o Partido dos Trabalhadores já vinha sinalizando sua intenção em modificar o Modelo Institucional do Setor Elétrico Brasileiro, através de documento intitulado Diretrizes e Linhas de 
Ação para o Setor Elétrico Brasileiro [Instituto Cidadania, 2002]. Não havia, entretanto, maior detalhamento da proposta.

Com a vitória do presidente Luiz Inácio Lula da Silva, em dezembro de 2002, houve a divulgação de uma primeira proposta para o modelo, que em suma previa a reregulamentação das atividades de geração e comercialização, transformando a primeira em Serviço Público (em contraste com a figura do Produtor Independente de Energia) e praticamente relegando a segunda em monopólio das distribuidoras [Sauer, 2002].

\subsection{A primeira proposta oficial de modelo}

Após a posse do governo recém eleito, com a nomeação da Ministra de Minas e Energia Dilma Rousseff e seu gabinete, foi montada uma equipe de trabalho responsável pela elaboração de um novo Modelo Institucional. Em julho de 2003, foi divulgado pelo MME documento indicando as premissas sobre as quais o modelo deveria ser construído [MME, 2003a]:

- Modicidade tarifária para os consumidores;

- Continuidade e qualidade na prestação do serviço;

- Justa remuneração para os investidores, de modo a incentivá-los a expandir o serviço;

- Universalização do acesso e do uso dos serviços de energia elétrica.

Além disso, em sua implantação, deveriam ser observados os seguintes pressupostos:

- Respeitar os contratos existentes;

- Minimizar os custos de transação durante o período de implantação;

- Não criar pressões tarifárias adicionais para o consumidor;

- Criar um ambiente propício à retomada de investimentos;

- Implantar, de forma gradual, o modelo proposto.

Os princípios básicos desta proposta inicial podem ser resumidos como segue:

- Prevalência do conceito de serviço público 
- Modicidade tarifária

- Mitigação dos riscos sistêmicos

- Universalização do acesso e do uso dos serviços de eletricidade

- Transparência - contestação pública

Um dos princípios mais controversos do arranjo institucional que se propunha era que a produção de energia deveria ser realizada, prioritariamente, por concessionário de serviço público, principalmente aquela destinada aos consumidores cativos [MME, 2003a]. As implicações práticas deste princípio seguem abaixo.

\subsubsection{As relações contratuais na primeira proposta de modelo}

As relações contratuais e comerciais no modelo proposto se assemelhariam bastante àquelas praticadas hoje no segmento de transmissão, com algumas adaptações necessárias. A ACEE - Administradora de Contratos de Energia Elétrica (entidade que seria criada para, entre outras funções, suceder ao MAE na liquidação de curto prazo) desempenharia um papel semelhante ao ONS no que diz respeito à administração dos serviços de geração prestados pelas geradoras.

Assim, uma vez realizado o processo licitatório de geração, as geradoras firmariam CPSG - Contratos de Prestação de Serviços de Geração - com a ACEE, através dos quais seriam primordialmente estabelecidos os termos e as condições de administração e coordenação, por parte da ACEE, da prestação de serviços de geração pelas geradoras às distribuidoras. Por sua vez, as distribuidoras firmariam CUSG - Contratos de Uso do Sistema de Geração - com a ACEE, por meio dos quais seriam primordialmente estabelecidos os termos e as condições do uso do sistema de geração pelas distribuidoras. O mecanismo de garantia seria respaldado pela assinatura de CCG - Contratos de Constituição de Garantia - pela ACEE, geradoras, distribuidoras e banco(s), que estabeleceriam os termos e as condições da garantia de pagamento e fiel cumprimento das obrigações pelas partes envolvidas. 
Em última análise, o conjunto formado por estes contratos decorrentes do processo licitatório de geração constituiria uma espécie de PPA - Contrato de Compra e Venda de Energia Elétrica - dos empreendimentos. A Figura 2.1 apresenta uma equivalência entre o modelo contratual e comercial aplicado à transmissão e o que estava sendo proposto para a geração.

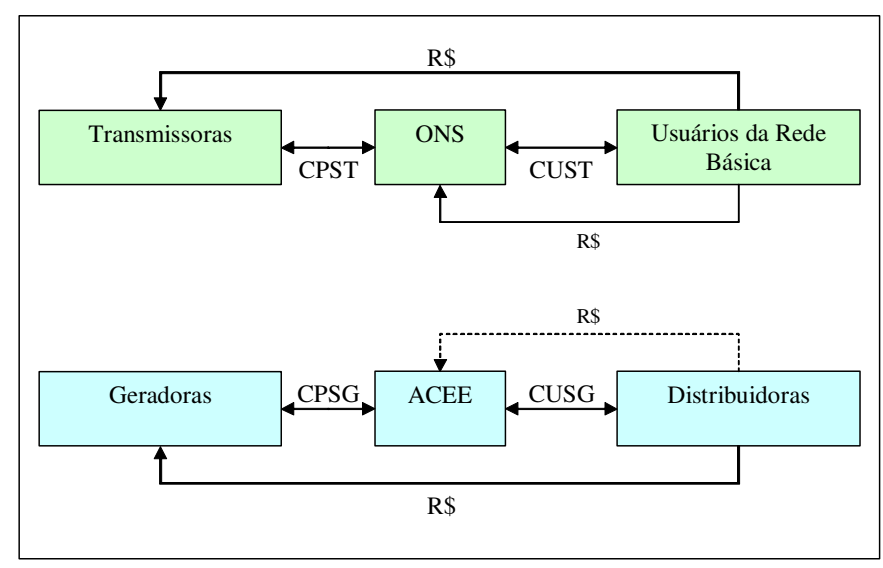

Figura 2.1 - Equivalência entre as relações contratuais e comerciais

\subsubsection{As relações comerciais na primeira proposta do modelo}

As relações comerciais no modelo proposto seriam, também, semelhantes àquelas praticadas hoje no segmento de transmissão, com a ACEE assumindo a coordenação do faturamento e liquidação. Uma forma possível de operacionalização do esquema proposto consistiria no suprimento de cada distribuidora por todas as geradoras. Portanto, cada geradora seria remunerada por todas as distribuidoras, possivelmente na proporção das suas respectivas demandas contratadas. A distribuição de contratos seria feita na medida em que os processos licitatórios de geração fossem realizados e, em tese privilegiaria as fontes que oferecessem suas capacidades pelas tarifas mais baratas, permitindo que as distribuidoras tivessem acesso a todas as fontes licitadas. Pulverizaria, então, o risco de crédito, como acontece no segmento de transmissão.

O modelo proposto se baseava, portanto, na definição de receitas autorizadas de geração em Reais mensais. 
Alguns inconvenientes e dificuldades contribuíram para que essa primeira proposta sofresse significativas alterações. Um dos principais é que, por definição, o preço do comprador único ("pool") deveria ser sempre único para todas as Distribuidoras. Como a cada momento a necessidade de contratação de energia por cada Distribuidora é proporcionalmente diferente - em função de diferentes crescimentos de mercado e contratos pré-existentes - a titularidade de um contrato de um gerador deveria variar ao longo do tempo, trazendo importante impacto nas garantias a serem depositadas por cada comprador. De fato, a complexa implementação de uma sistemática adequada para as garantias contratuais (montantes contratados e titularidade dos contratos, no que concerne aos compradores, seriam alterados a cada licitação do "pool") resultou um dos principais inibidores da materialização da formulação inicialmente adotada no início do atual Governo, conduzindo a uma reformulação bastante abrangente do arranjo institucional em maturação à época.

\subsection{A versão "final” do Modelo}

Após reuniões com os agentes setoriais e críticas à primeira proposta do modelo, em dezembro de 2003 o MME publicou a versão "final" do Modelo Institucional [MME, 2003b], juntamente com as Medidas Provisórias 144, que dispunha sobre a comercialização de energia elétrica, e 145, que criava a EPE - Empresa de Pesquisa Energética. Exceto por algumas alterações pontuais, este é o modelo em vigor.

Em seguida, a Medida Provisória 144 viria a se tornar a Lei 10.848/2004, regulamentada pelo Decreto 5.163 de 30 de julho de 2004.

\subsubsection{Premissas do Modelo}

O modelo proposto no documento divulgado pelo Ministério de Minas e Energia (MME) e que serviu de base para a regulamentação, teve como premissas três objetivos principais:

1) Garantir a segurança de suprimento de energia elétrica; 
2) Promover a modicidade tarifária, por meio da contratação eficiente de energia para os consumidores regulados; e

3) Promover a inserção social no Setor Elétrico, em particular pelos programas de universalização do atendimento.

Particularmente, no que tange ao segundo objetivo, o referido documento argumenta que as principais ações para promover a contratação eficiente de energia para os consumidores regulados seriam:

- Proceder à compra de energia sempre por meio de leilões, na modalidade "menor tarifa";

- Contratar energia por licitação conjunta dos distribuidores (pool), visando obter economia de escala na contratação de energia de novos empreendimentos, repartir riscos e benefícios contratuais e equalizar tarifas de suprimento; e

- Contratar separadamente a energia de novas usinas (atendimento à expansão da demanda) e de usinas existentes, ambas por licitação [MME, 2003b].

Para atender a essas premissas, foram criados dois ambientes contratuais - um regulado e um livre, bem como novos organismos para garantir a funcionalidade do mercado de acordo com os objetivos preconizados no modelo.

Importante frisar que nesta versão final não existe mais a figura do preço único do “pool” para todas as Distribuidoras. De fato, após os leilões cada vendedor assina contratos bilaterais com cada comprador, de tal forma que o preço se configura único para as Distribuidoras participantes de um determinado leilão (de energia "nova" ou "velha”), apenas no que respeita à parcela de contratos adquiridos nesse mesmo leilão. Cada Distribuidora assina contratos bilaterais com cada gerador vendedor no leilão em questão, com a duração pré estabelecida no Edital, aos preços de venda individuais resultantes do processo competitivo. 


\subsubsection{Novos Organismos Setoriais}

Os novos agentes institucionais do Setor, criados no âmbito do modelo em implantação, são a Empresa de Pesquisa Energética - EPE, a Câmara de Comercialização de Energia Elétrica - CCEE e o Comitê de Monitoramento do Setor Elétrico - CMSE.

\subsubsection{Empresa de Pesquisa Energética - EPE}

O exercício da função de executor do planejamento energético, e em particular do Setor Elétrico, é atribuição do Estado, como agente normativo e regulador da atividade econômica (art. 174 da Constituição Federal). O desempenho de tal função requer o desenvolvimento de estudos complexos e multidisciplinares, que demandam elevado grau de qualificação e especialização profissional.

Além disso, no desenvolvimento do processo de planejamento, é essencial garantir a credibilidade, a representatividade e a transparência dos estudos, em especial, por meio da disponibilização de dados, premissas, critérios, métodos e resultados, de maneira pública e isonômica, a todos os agentes.

Para tanto, foi criada uma instituição técnica especializada - a Empresa de Pesquisa Energética - EPE - através da Lei 10.847/2004 com o objetivo de, principalmente, desenvolver os estudos necessários para que o MME possa cumprir plenamente sua função de executor de planejamento energético, com as seguintes responsabilidades:

- execução de estudos para definição da Matriz Energética, com indicação das estratégias a serem seguidas e das metas a serem alcançadas, dentro de uma perspectiva de longo prazo;

- execução dos estudos de planejamento integrado dos recursos energéticos;

- execução dos estudos do planejamento da expansão do Setor Elétrico (geração e transmissão); 
- promoção dos estudos de potencial energético, incluindo inventário de bacias hidrográficas; e

- promoção dos estudos de viabilidade técnico-econômica e sócioambiental de usinas, bem como obtenção da Licença Prévia Ambiental para aproveitamentos hidrelétricos.

Apesar de não ter como atribuição prevista inicialmente, a EPE também recebeu o papel de formulador das regras dos quatro primeiros leilões de energia existente, bem como do primeiro leilão de energia nova. Após a realização do leilão de energia nova, foi criada Comissão Especial dos Leilões de Energia Elétrica - CELEE com tal função.

\subsubsection{Câmara de Comercialização de Energia Elétrica - CCEE}

A Câmara de Comercialização de Energia Elétrica - CCEE foi criada para suceder ao MAE absorvendo suas funções e incorporando todas as estruturas organizacionais e operacionais deste, conseqüentemente com os seguintes objetivos:

- administrar a contratação de compra e venda de energia dos concessionários do serviço público de distribuição;

- realizar leilões para compra de energia para os distribuidores, desde que autorizados pela Aneel; e

- exercer as funções de contabilização e liquidação do MAE, nos dois ambientes de contratação, o ACR e o ACL.

\subsubsection{Comitê de Monitoramento do Setor Elétrico - CMSE}

A segurança de suprimento, que é um dos objetivos básicos do modelo em implantação, requer ação contínua e permanente de monitoramento, a qual permitirá o encaminhamento tempestivo de ações preventivas de mínimo custo para o consumidor. 
Dentre os eventos que podem afetar a segurança de suprimento e, portanto, devem ser monitorados, incluem-se, dentre outros,

- não-cumprimento do cronograma de construção de empreendimentos;

- condições hidrológicas excepcionalmente adversas; e

- aumento imprevisto do consumo.

Neste sentido, foi instituído, no âmbito do MME, o CMSE, de caráter permanente, com a função de analisar a continuidade e a qualidade de suprimento num horizonte de cinco anos e propor ao CNPE (Conselho Nacional de Política Energética, vide a seguir) medidas preventivas de mínimo custo para restaurar as condições adequadas de atendimento, incluindo ações no lado da demanda, da contratação de reserva conjuntural e outras.

O CMSE é coordenado pelo MME e tem a participação formal e permanente das seguintes instituições: EPE, CCEE, ONS e ANEEL. A critério da coordenação, e para apreciação de assuntos específicos, poderão ser convidadas a participar outras instituições como, por exemplo, BNDES, ANA e IBAMA. [MME, 2003b].

\subsubsection{Adaptações às atribuições das instituições já existentes}

Além da criação dos três organismos acima, as instituições já existentes tiveram algumas de suas atribuições alteradas. As alterações mais significativas são as apresentadas.

O Conselho Nacional de Política Energética - CNPE, além de se manter como responsável pela proposição da política energética nacional ao Presidente da República, em articulação com as demais políticas públicas, passou a assumir as seguintes funções:

- Proposição da licitação individual de projetos especiais do Setor Elétrico, recomendados pelo MME; e

- Proposição do critério de garantia estrutural de suprimento. 


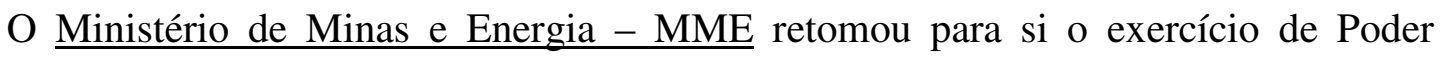
Concedente (que havia sido legado à ANEEL no modelo anterior), atuando ainda:

- Na formulação e implementação de políticas para o Setor Energético, de acordo com as diretrizes do CNPE;

- No exercício da função de planejamento setorial;

- No monitoramento da segurança de suprimento do Setor Elétrico, por intermédio do CMSE; e

- Na proposição de ações preventivas, a serem referendadas pelo CNPE, visando à restauração da segurança de suprimento, no caso de desequilíbrios conjunturais entre oferta e demanda, tais como gestão da demanda e/ou contratação de reserva conjuntural de energia do sistema interligado.

A Agência Nacional de Energia Elétrica - ANEEL, que pode atuar sob delegação do MME no papel de Poder Concedente, no novo desenho regulatório ficou com as seguintes atribuições:

- Mediação, regulação e fiscalização do funcionamento do Sistema Elétrico;

- Realização de leilões de concessão de empreendimentos de geração e transmissão por delegação do MME; e

- Licitação para aquisição de energia para os distribuidores. [MME, 2003b]

\subsubsection{Sumário das principais alterações introduzidas pelo Modelo e suas motivações}

A despeito do que possa parecer pela leitura das premissas do modelo divulgadas pelo Ministério de Minas e Energia, as duas principais alterações de fato trazidas pelo modelo em tela são:

- Leilões separados para energia nova; e

- Compra de energia através de leilões. 
A primeira alteração - separação da compra da energia proveniente de novos empreendimentos de geração - visa a resolver uma das maiores críticas ao modelo anterior (Re-seb), qual seja sua dificuldade em viabilizar a expansão. Ainda, através da licitação de novos aproveitamentos com Contratos de Venda de Energia de Longo Prazo associados, também conhecidos como PPA - Power Purchase Agreement, facilita-se a obtenção de financiamento na modalidade de Project Finance ${ }^{4}$, uma vez que as garantias seriam oferecidas na forma dos recebíveis dos CCEARs assinados.

A segunda alteração significativa - realização de licitações para a aquisição de energia elétrica - visa garantir transparência no processo de contratação de energia para atendimento ao mercado cativo, reduzindo o poder discricionário das distribuidoras e concorrendo para a modicidade tarifária.

Sinteticamente, a evolução dos modelos pode ser ilustrada na linha do tempo abaixo:

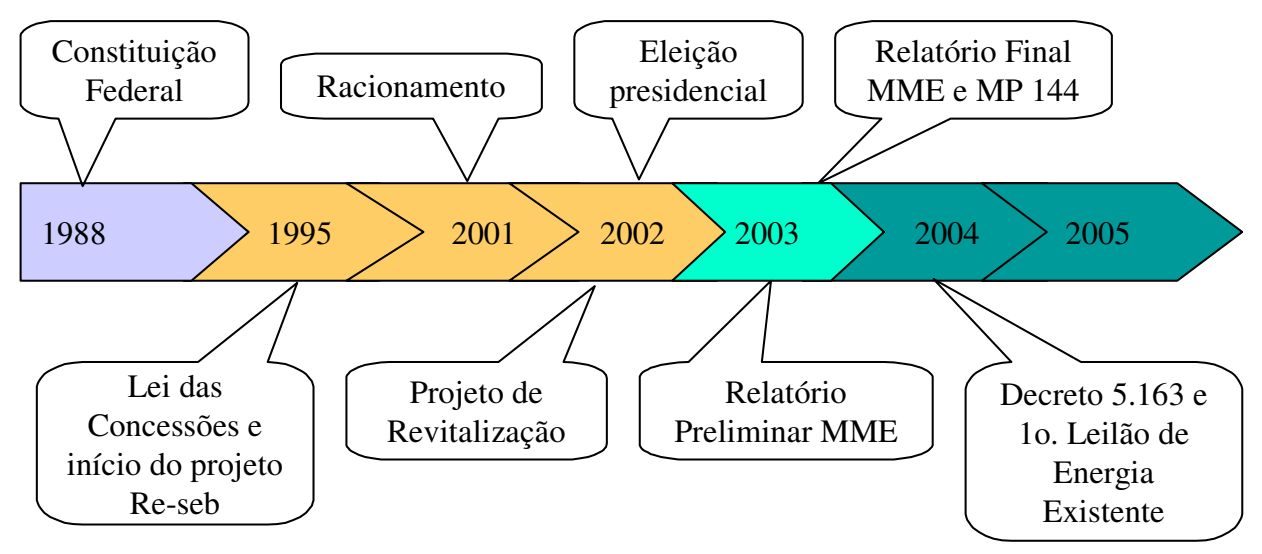

Figura 2.2 - Linha do tempo dos modelos

${ }^{4}$ O termo Project Finance define-se como uma modalidade de financiamento cujo processo de avaliação, estruturação e concessão dos recursos está calcado, primordialmente, na capacidade financeira do projeto. A decisão dos credores se baseará na capacidade do projeto em saldar suas dívidas e remunerar o capital, sem contar com os fluxos de caixa de outros empreendimentos dos acionistas [Borges e Faria, 2002]. 


\section{RELAÇÕES CONTRATUAIS E COMERCIAIS NO MODELO DO SETOR ELÉTRICO}

\subsection{A natureza do contrato de compra e venda de energia elétrica}

Os contratos são instrumentos puramente financeiros, cujo único objetivo é reduzir a volatilidade dos pagamentos no mercado de curto prazo. Em outras palavras, um gerador assina um contrato para se proteger contra preços de curto prazo reduzidos, enquanto que os compradores (comercializadores e consumidores livres) tenderão a buscar contratos para se proteger contra preços de curto prazo elevados.

A assinatura de um contrato expõe o gerador a um outro tipo de risco, que é o de ser obrigado a comprar energia no mercado de curto prazo a preços elevados para complementar a diferença entre a energia alocada e sua energia assegurada (a este respeito, vide item 3.5.2). No caso de uma usina térmica, este risco é relativamente pequeno, pois os períodos de preço de curto prazo elevado a planta estará gerando em sua capacidade máxima e, portanto, atendendo a seu contrato . No caso de uma hidrelétrica, entretanto, este risco é substancial, pois os períodos de preços de curto prazo elevados são justamente os de seca severa, onde sua produção diminui [Ramos, Fadigas e Lima, 2000].

\subsubsection{Características de um contrato de energia}

Um contrato de compra e venda de energia elétrica é caracterizado por três variáveis básicas:

- Preço: valor, em R $\$ / M W h$, da energia comercializada

- Prazo: duração do contrato;

- Volume: quantidade de energia a ser comercializada, em MWh

Adicionalmente, outras características são importantes na formação do preço e avaliação dos riscos do negócio: 
- Início de suprimento: data de início da entrega de energia. É um parâmetro importante, pois define a proximidade entre a data de fechamento do contrato e a de entrega efetiva de energia, com os riscos e incertezas inerentes a esta distância, impactando de forma significativa no preço do contrato;

- Ponto de entrega: local de entrega da energia, podendo ser na barra da geração, no centro de gravidade ${ }^{5}$ do submercado da geração, no centro de gravidade do submercado da carga ou na barra da carga. Sua importância na formação do preço da energia é relevante à medida que define a quem caberá a cobertura das perdas elétricas (também conhecidas como perdas técnicas) decorrentes do negócio, bem como qual parte estará eventualmente exposta a eventuais diferenças de preços entre submercados.

\subsection{Ambientes de contratação}

Conhecidos os parâmetros de um contrato de energia, passa-se agora aos ambientes de contratação previstos no Modelo:

- Ambiente de Contratação Regulada - ACR: compreende a contratação de energia para atendimento aos consumidores regulados (consumo cativo dos distribuidores, ou seja, consumidores residenciais, comerciais e industriais que não atendem aos requisitos para se tornarem livres ${ }^{6}$ ou, ainda que atendam a tais requisitos, não tenham exercido esta opção) por meio de contratos regulados; e

\footnotetext{
${ }^{5}$ Centro de Gravidade é um ponto fictício do sistema, que não necessariamente corresponde a uma barra física, definido de tal forma que as perdas elétricas causadas por geradores e consumidores sejam igualmente divididas.

${ }^{6}$ De acordo com a Lei 9.074/1995, podem optar livremente pelo fornecedor de energia os consumidores cuja demanda seja maior ou igual a 3 MW e atendidos em nível de tensão a partir de 69 kV, se conectados antes de julho de 1995, ou em qualquer nível de tensão, se conectados após esta data. Consumidores cuja demanda seja maior ou igual a $500 \mathrm{~kW}$, em qualquer nível de tensão, também podem optar pela compra de energia a partir de fontes alternativas, de acordo com a lei $9.427 / 1996$.
} 
- Ambiente de Contratação Livre - ACL: compreende a contratação de energia para atendimento aos consumidores livres, por intermédio de contratos livremente negociados.

\subsubsection{O Ambiente de Contratação Regulada}

Deste ambiente de contratação, participam todas as distribuidoras, as quais devem atender a totalidade de seus mercados (consumidores cativos). Todas as aquisições de energia devem ser feitas por meio de licitações, com a realização de leilões por menor preço de energia, cujos vendedores devem assinar contratos com todos as distribuidoras participantes do leilão em questão ( $P o o l$ de compra).

Há uma segmentação do mercado das distribuidoras de forma que:

- os novos empreendimentos (energia nova) deverão ser comercializados para atender à expansão do mercado, mediante licitações que se realizarão em cinco ou três anos antes da data de início de entrega da energia elétrica, por meio de contratos com duração de 15 a 35 anos;

- os empreendimentos existentes serão comercializados exclusivamente para atender à demanda atual, mediante contratos com duração de 3 a 15 anos em licitações realizadas com um ano de antecedência.

A idéia contida nesta segmentação é a de que a energia gerada por usinas existentes (energia "velha") e, teoricamente, já amortizadas, poderia ser comercializada por preços menores do que aquela gerada pelas novas usinas, cujos preços tenderiam ao Custo Marginal de Expansão.

\subsubsection{O Ambiente de Contratação Livre}

Neste ambiente podem participar todos os geradores, comercializadores e consumidores livres, com total liberdade para negociarem seus contratos de compra e venda de energia. 
A figura a seguir ilustra a convivência entre os ambientes.

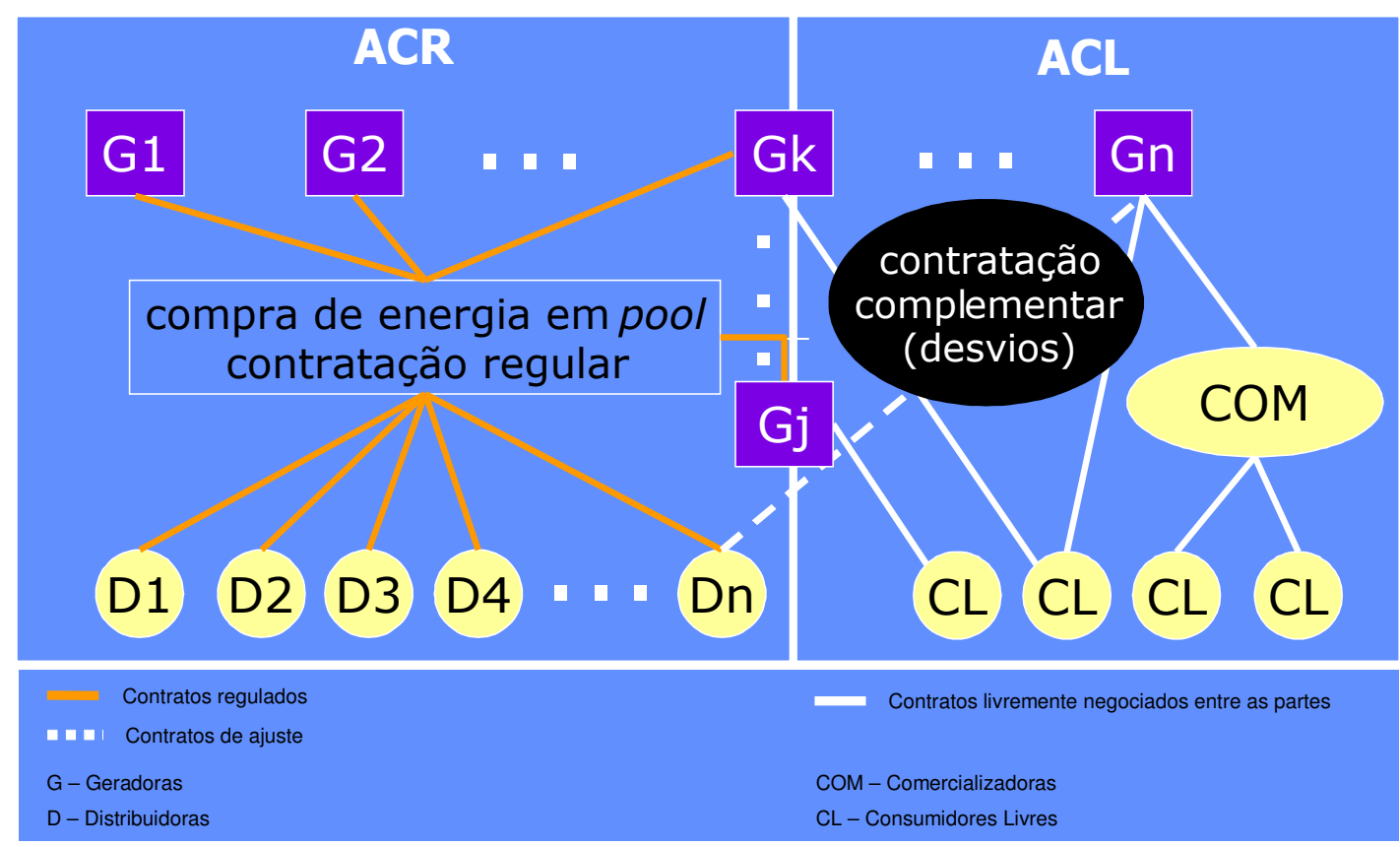

Figura 3.1 - Visão geral das relações contratuais

\subsubsection{O mercado de curto prazo}

Como a energia elétrica tem a característica de não ser armazenável em grandes quantidades e de forma economicamente viável após ter sido gerada, o balanço produção-consumo deve ser feito instantaneamente, de forma que pode haver diferenças entre o volume contratado e o consumido. Essa diferença deve ser liquidada no mercado de curto prazo, valorado a um preço que reflita o custo marginal de operação do sistema. Este valor é chamado de PLD (preço de liquidação de diferenças).

O custo marginal de operação do sistema elétrico é, de forma simplificada, dado pela usina térmica mais cara despachada por motivos energéticos ou pelo valor da água naquele instante. É obtido através da utilização de uma cadeia de aplicativos de otimização do sistema (Newave e Decomp, desenvolvidos pelo CEPEL). 
O valor máximo do PLD ("teto" ou "cap") é definido com base no custo variável de operação da geração térmica mais cara disponível para participar do despacho centralizado. O valor em vigor para o ano de 2005, definido pela Resolução Homologatória ANEEL 286/2004, é de 507,28 R\$/MWh.

O valor mínimo do PLD ("piso" ou "floor") é estabelecido pela ANEEL, contemplando os custos da operação e a manutenção das usinas hidrelétricas e as compensações financeiras pelo uso dos recursos hídricos [MME, 2003b]. Para o ano de 2005, este valor mínimo para o PLD está vinculado ao custo de operação e manutenção da UHE Itaipu, tendo sido fixado em 18,33 R $\$ / \mathrm{MWh}$, conforme Despacho 001/2005 da Superintendência de Estudos Econômicos do Mercado (SEM) da ANEEL.

\subsection{A regulamentação das relações contratuais e comerciais}

Em 30 de julho de 2004 foi assinado o Decreto 5.163, regulamentando a Lei 10.848 de 14 de março de 2004, que trata da comercialização de energia elétrica e do processo de outorga de concessões e de autorizações de geração de energia elétrica.

O Decreto está dividido em seis capítulos, sendo que o capítulo 2 está subdividido em cinco seções:

1. Regras Gerais de Comercialização de Energia Elétrica

2. Comercialização de energia no Ambiente de Contratação Regulada

Seção 1 - Disposições Gerais

Seção 2 - Informações e Declarações de Necessidades de Energia Elétrica

Seção 3 - Leilões para Compra de Energia Elétrica

Seção 4 - Contratos de Compra e Venda de Energia Elétrica

Seção 5 - Repasse às Tarifas dos Consumidores Finais

3. Comercialização de energia do Ambiente de Contratação Livre

4. Contabilização e Liquidação de Diferenças no Mercado de Curto Prazo

5. Outorgas de Concessão 
6. Disposições Finais e Transitórias

A seguir, passa-se ao detalhamento do conteúdo dos capítulos que mais impactam nas estratégias de comercialização de energia dos geradores existentes [MME, 2004]:

\subsubsection{Regras Gerais de Comercialização}

Este capítulo apresenta as definições essenciais do Decreto, destacando-se:

- Ambiente de Contratação Regulada - ACR, no qual se realizam as operações de compra e venda de energia envolvendo as distribuidoras;

- Ambiente de Contratação Livre - ACL, no qual as operações de compra e venda são livremente negociadas;

- Consumidor Livre é aquele que tenha exercido a opção de contratar energia elétrica, atendido em tensão igual ou superior a $69 \mathrm{kV}$, cuja demanda exceda de 3 MW;

- Consumidor Potencialmente Livre é aquele que compra energia da concessionária de distribuição da área onde está localizada a instalação consumidora, não obstante tenha condições de optar por outro fornecedor de energia elétrica.

- Agentes Vendedores - titulares de concessão, permissão ou autorização do Poder Concedente para gerar, importar ou comercializar energia elétrica;

- Agentes de Distribuição - titulares de concessão, permissão ou autorização de serviços e instalações de distribuição para fornecer energia elétrica a consumidor final exclusivamente de forma regulada.

Além das definições, o capítulo estabelece os dois princípios básicos para a segurança do suprimento:

- Todo agente de consumo está obrigado a contratar $100 \%$ de sua carga; 
- Cada contrato de venda de energia deve ter um lastro físico de geração, de forma que não existam contratos sem a correspondente capacidade de suprimento.

O Decreto estabelece ainda diretrizes para a aferição do atendimento à primeira obrigação - contratar $100 \%$ das cargas (no caso da energia, verificada anualmente no mês de janeiro sobre o consumo ocorrido nos últimos doze meses) e remete as penalidades por não-cumprimento à Convenção de Comercialização da Câmara de Comercialização de Energia Elétrica - CCEE.

No caso da segunda obrigação - lastro físico de geração -, o Decreto determina que o lastro de cada empreendimento constará do respectivo contrato de concessão ou ato de autorização.

Finalmente, este capítulo estabelece o tratamento a ser dado quando o empreendimento de geração que serve de lastro para um contrato não é concluído a tempo, ou quando sofre indisponibilidade prolongada. Nestes casos, o responsável pelo empreendimento terá a obrigação de recompor o lastro físico de seus contratos de venda de energia, sem prejuízo de penalidades estabelecidas pela ANEEL.

\subsubsection{Comercialização no $A C R$}

\subsubsection{Disposições Gerais}

Esta seção especifica que para cumprir a obrigação de atendimento a $100 \%$ de sua carga, os distribuidores devem utilizar as seguintes formas de contratação:

- Leilões de compra de energia, a saber:

- Leilões de energia proveniente de novos empreendimentos de geração;

- Leilões de compra de energia proveniente de empreendimentos existentes; 
- Leilões de ajuste (nos quais também é adquirida energia proveniente de empreendimentos existentes).

- Aquisição de energia de geração distribuída.

Além disto, no cumprimento dessa obrigação, serão também considerados os contratos decorrentes de:

- Energia contratada na primeira etapa do PROINFA - Programa de Incentivo às Fontes Alternativas de Energia Elétrica;

- Aquisições anteriores à Lei No 10.848 (ou seja, firmados antes de 16 de março de 2004);

- Energia proveniente de Itaipu Binacional; e

- Compra de energia do supridor atual com tarifas reguladas (somente para distribuidoras de pequeno porte, com mercado inferior a $500 \mathrm{GWh} / \mathrm{ano}$ ).

O Decreto define o que é energia proveniente de novos empreendimentos e estabelece que o MME apresentará a lista de empreendimentos de geração aptos a participar dos leilões de novos empreendimentos, a partir de estudos da Empresa de Pesquisa Energética - EPE - e de ofertas de investidores.

Também define geração distribuída e determina que sua contratação deverá ser precedida de chamada pública e estará limitada, no total, a 10\% da carga do distribuidor. O preço teto de repasse estará limitado ao Valor Anual de Referência VR, que é uma média ponderada dos custos de aquisição de energia nos leilões de "A-3" e "A-5", realizados a 3 anos e 5 anos do ano alvo (vide Figura 3.2), respectivamente, calculado para o conjunto de todas as distribuidoras.

\subsubsection{Declarações de Necessidades}

Esta seção apresenta duas regras básicas: 
- Todo agente distribuidor, vendedor, autoprodutor ou consumidor livre tem a obrigação de declarar, em cada ano, sua previsão de mercado ou carga, para cada um dos cinco anos subseqüentes. Esta declaração será utilizada no planejamento da expansão do sistema;

- Cada agente de distribuição deve declarar, até sessenta dias antes de cada leilão de energia proveniente de empreendimentos existentes ou de energia proveniente de novos empreendimentos, os montantes de energia que deverá contratar nos leilões. Esta declaração, bem como a expectativa de redução dos contratos de energia existente, são os objetos de simulação do modelo desenvolvido.

\subsubsection{Leilões para Compra de Energia Elétrica}

Esta seção define as opções para compra de energia elétrica no ACR, quais sejam leilões de:

(i) energia proveniente de novos empreendimentos, realizados cinco anos antes do início da entrega da energia - chamados de leilões "A-5";

(ii) energia proveniente de novos empreendimentos, realizados três anos antes do início da entrega - leilões "A-3";

(iii) energia de empreendimentos existentes, realizados no ano anterior ao de início da entrega da energia - leilões “A-1"; e

(iv) ajustes, também de energia proveniente de empreendimentos existentes, com início de entrega em até 4 meses.

A figura abaixo ilustra os diversos momentos em que uma distribuidora pode recorrer à contratação de energia. 


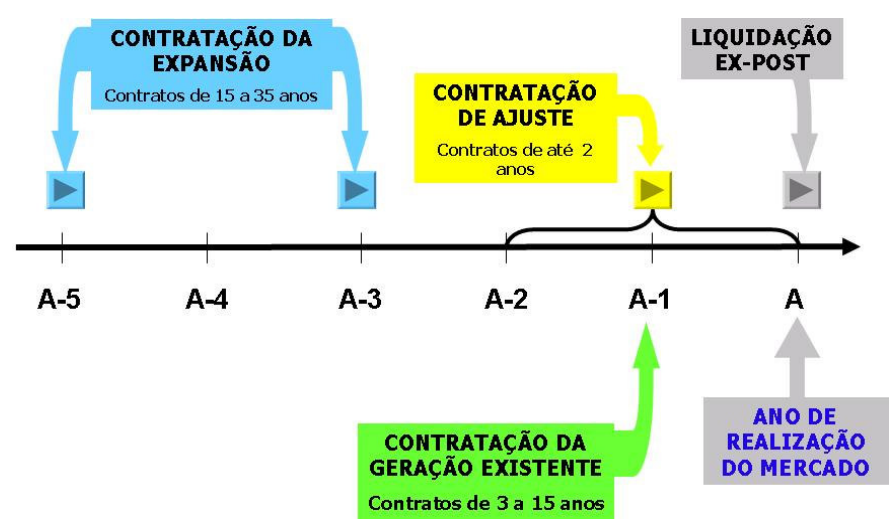

Figura 3.2 - Opções de contratação das distribuidoras

O MME deverá definir o preço máximo de aquisição nos leilões de energia proveniente de empreendimentos existentes. A partir de 2009, o preço máximo não poderá superar o valor médio resultante dos leilões de compra de energia elétrica proveniente de novos empreendimentos realizados no ano "A-5", cujo início de suprimento coincida com o ano do leilão de "A-1".

Adicionalmente, é estabelecido o seguinte:

- Os editais dos leilões serão elaborados pela ANEEL observando diretrizes do MME, notadamente:

○ a utilização do critério de menor tarifa no julgamento;

- o valor do pagamento anual pelo Uso do Bem Público - UBP, no caso de novas concessões;

○ uma fórmula que permite a participação nos leilões, em igualdade de condições, de investidores que pretendam utilizar parte da energia do empreendimento hidrelétrico leiloado para uso próprio ou para comercialização no ACL e outra parte destinada ao suprimento do consumidor cativo do ACR. A fórmula objetiva incentivar o investidor a destinar mais energia ao mercado regulado, o ACR, proporcionando um ganho a ser utilizado em benefício da modicidade tarifária; 
○ o detalhamento das condições de participação de empreendimentos que entraram em operação a partir de 2000 nos leilões de energia proveniente de novos empreendimentos;

○ a definição do tratamento a ser dado, nos leilões de energia proveniente de novos empreendimentos, às usinas que obtiveram suas concessões com base em máximo pagamento de UBP, com o objetivo de compensar uma eventual desvantagem dessas usinas numa licitação por menor tarifa;

- o limite máximo para a quantidade de energia adquirida pelas distribuidoras nos leilões de energia proveniente de empreendimentos existentes. Este limite $(105 \%$ da reposição dos contratos da distribuidora que estejam vencendo) evita que as distribuidoras adquiram no futuro energia proveniente de empreendimentos existentes no lugar de energia proveniente de novos empreendimentos que seria necessária para atender à expansão do sistema, o que poderia comprometer a segurança do suprimento;

- as regras para os leilões de energia provenientes de empreendimentos existentes durante o período de transição. $\mathrm{O}$ objetivo é permitir que a energia descontratada devido ao excesso conjuntural de oferta em relação à demanda tenha a oportunidade de ser contratada pelas distribuidoras, proporcionando maior tranqüilidade aos geradores e contribuindo para o funcionamento normal do modelo desde seu início de implantação;

○ energia de origem hidrelétrica contratada na modalidade "contratos de quantidade" $^{, 7}$ e energia de origem termelétrica contratada na modalidade "contratos de disponibilidade",

\footnotetext{
${ }^{7}$ Contratos por "quantidade de energia" são aqueles nos quais o agente vendedor assume os riscos hidrológicos.

${ }^{8}$ Contratos por "disponibilidade de energia" são aqueles nos quais os agentes compradores assumem os riscos hidrológicos (e com isto podem adquirir energia por um preço mais reduzido). Em outras palavras, o custo de combustível e os custos variáveis de operação da termelétrica são assumidos diretamente pelos compradores, que se beneficiam da operação em complementação térmica, em
} 
entrega será sempre no Centro de Gravidade do submercado onde esteja localizado o empreendimento de geração, de forma que os riscos impostos por diferenças de preços entre submercados ficam alocados às Distribuidoras, com direito de repasse aos consumidores finais ${ }^{9}$;

○ o limite máximo para o total de energia contratada pela distribuidora em leilões de ajuste (1\% da carga da distribuidora), para impedir que o distribuidor opte por não contratar energia proveniente de novos empreendimentos que poderia levar ao desabastecimento.

\subsubsection{Contratos de Compra e Venda de Energia}

Esta seção determina que os vencedores de cada leilão de energia do ACR deverão firmar contratos bilaterais com todas as distribuidoras que estejam adquirindo energia no leilão em tela, contratos esses denominados Contratos de Comercialização de Energia em Ambiente Regulado, CCEAR, com volumes definidos em proporção às respectivas declarações de necessidade. A única exceção é o leilão de ajuste, onde os contratos são específicos entre agente vendedor e agente de distribuição.

São especificadas as durações mínima e máxima para os CCEAR provenientes dos leilões "A-5" ou "A-3" (15 a 30 anos) e "A-1" (3 a 15 anos) e estabelecida existência de cláusula arbitral.

Excepcionalmente para os leilões da transição promovidos pela ANEEL em 2004 e 2005, a seção anterior define que o prazo mínimo de vigência dos contratos de compra de energia elétrica proveniente de empreendimentos de geração existentes

períodos hidrológicos favoráveis, bem como assumem os custos de operação na base em períodos hidrológicos adversos. A receita do contrato de disponibilidade, para o vendedor, objetiva tão somente remunerar os investimentos realizados e cobrir os custos de operação e manutenção fixos, caracterizando, desse ponto de vista, um contrato de "leasing" das instalações.

${ }^{9}$ Exceto nos contratos dos leilões de ajuste, onde a entrega será no centro de gravidade do submercado do comprador. 
será de oito anos para o início do suprimento a partir de 2005, 2006 e 2007 e de no mínimo cinco anos para o início do suprimento a partir de 2008 e 2009.

Para os CCEAR decorrentes de leilões de energia proveniente de empreendimentos existentes, o Decreto estabelece três possibilidades de redução das quantidades contratadas:

- compensação pela saída de consumidores potencialmente livres - os distribuidores, após utilizarem o mecanismo de compensação de sobras e déficits (mecanismo que faz parte da Convenção de Comercialização), poderão reduzir seus contratos no montante equivalente ao saldo não compensado devido à saída do consumidor livre;

- redução, a critério da distribuidora, de até $4 \%$ do montante contratado para adaptar-se aos desvios do mercado face às projeções de demanda; $\mathrm{e}$

- adaptação às regras estipuladas nos contratos de geração pactuados até 11 de dezembro de 2003.

Nos três casos as reduções serão aplicadas uniformemente entre todos os CCEAR da distribuidora, decorrentes de leilões de energia proveniente de empreendimentos existentes.

\subsubsection{Repasse às Tarifas}

Esta seção apresenta as condições de repasse dos custos de aquisição de energia às tarifas dos consumidores finais. Também é definido um mecanismo para "indução de eficiência" na contratação das distribuidoras.

Considerando que os contratos resultam de leilões, poderia parecer, à primeira vista, que todos os custos de aquisição de energia deveriam ser automaticamente repassados às tarifas dos consumidores finais. Entretanto, como a quantidade de energia que cada distribuidora adquire em cada leilão é uma decisão da própria 
distribuidora, os mecanismos de repasse passam a ser indutores à contratação eficiente.

O primeiro mecanismo é o repasse de um valor único para compensar os custos de aquisição da energia proveniente de novos empreendimentos das distribuidoras, o VR, conforme definido anteriormente. Como conseqüência, a distribuidora que tiver um custo individual de contratação de energia proveniente de novos empreendimentos inferior a esta "média do mercado" terá um ganho. O VR é um estímulo para contratação eficiente em "A-5”, cujo custo de aquisição deverá, na maioria das situações, ser inferior ao da energia contratada em "A-3". O VR é aplicado nos três primeiros anos de vigência dos contratos de energia proveniente de novos empreendimentos. A partir do $4^{\circ}$ ano, os custos individuais de aquisição serão repassados integralmente.

O VR também é usado como limite máximo para repasse dos custos de aquisição de energia proveniente de empreendimentos existentes nos leilões de ajuste e para a contratação de geração distribuída. Ainda com o objetivo de induzir a contratação eficiente, existem as seguintes limitações ao repasse:

- A distribuidora pode repassar os montantes contratados até $103 \%$ de sua carga. Este limite pretende aumentar a segurança do sistema, pois reconheceria a impossibilidade de uma previsão perfeita da demanda e estabeleceria um limite aceitável para erros nesta projeção, assegurando que os contratos sejam no mínimo iguais à carga;

- Quando a contratação em "A-3" exceder de $2 \%$ da demanda, o direito de repasse está limitado ao menor dentre os custos de contratação relativos a "A5 " e "A-3";

- Se uma distribuidora contratar energia proveniente de novos empreendimentos em excesso para, posteriormente, ajustar-se descontratando energia proveniente de empreendimentos existentes, provocará uma ineficiência no uso de recursos do país, pois poderia demandar uma expansão antes do prazo de sua real necessidade, "desotimizando" o sistema. Com o 
objetivo de inibir esta prática, caso a aquisição de energia proveniente de empreendimento existente seja menor que o limite inferior de contratação, o repasse do custo de aquisição de energia proveniente de novos empreendimentos correspondente a esse valor não contratado será limitado por um redutor.

- No período de transição, de 2005 a 2008, a contratação de energia proveniente de empreendimentos existentes nos leilões "A-1" não deverá exceder a 1\% da demanda, porque todos os leilões deveriam ocorrer em 2004. O que exceder a este limite terá o repasse do custo de aquisição reduzido. Este mecanismo tinha por objetivo incentivar as distribuidoras a contratar o máximo de suas necessidades no leilão de energia proveniente de empreendimentos existentes durante a transição, realizado em 2004.

O limite inferior de contratação é o valor positivo resultante da seguinte equação:

$$
\mathrm{LI}=\mathrm{MR}-0,04 \cdot \mathrm{MI}
$$

Onde:

LI é o limite inferior de contratação

MR é o montante de reposição (quantidade de energia dos contratos que se extinguirem no ano do leilão, subtraídas as reduções)

MI é o montante inicial de energia elétrica dos CCEAR considerado para a apuração do MR.

À época, o MME sinalizava que com o objetivo de manter a neutralidade dos repasses dos custos de aquisição de energia das distribuidoras, componentes da Parcela A da tarifa, a ANEEL poderia adotar, levando em conta os doze meses subseqüentes, metodologia de cálculo para o reajuste tarifário, considerando o preço médio ponderado dos contratos de compra.

Além disso, tendo em vista a mudança na metodologia de reajuste e ainda com o objetivo de manter a neutralidade dos repasses de custos componentes da Parcela A, as variáveis resultantes dos custos de aquisição de energia elétrica, não consideradas 
no reajuste tarifário anterior, seriam contempladas nos mecanismos de compensação, a chamada CVA - Conta de Compensação dos Valores da Parcela A.

Durante o ano de 2005, todas as Distribuidoras foram chamadas a assinar aditivos ao Contrato de Concessão, contendo cláusulas que contemplam os contratos de leilão em antecipação nas tarifas, no momento do reajuste, sendo que os contratos bilaterais não provenientes de leilão fazem jus à CVA.

Ademais, a ANEEL deverá, a partir de janeiro de 2006, contemplar no reajuste ou revisão tarifária, a previsão dos custos com Encargos de Serviço de Sistema, outro componente da Parcela A, para os doze meses subseqüentes, ficando para a conta de compensação ou CVA apenas as eventuais diferenças com relação ao valor previsto e o valor efetivamente realizado.

\subsubsection{Comercialização de energia do ACL}

Neste capítulo são apresentadas as regras gerais para o tratamento das relações entre os consumidores potencialmente livres - CPL e as distribuidoras.

Dentre as questões tratadas está a declaração do CPL que optar por comprar energia de outro fornecedor. O exercício desta opção deverá ser informado à distribuidora até quinze dias antes das declarações de suas necessidades de energia para o leilão "A1". A aquisição de energia de outro fornecedor poderá ser iniciada somente a partir de janeiro do ano subseqüente ao da declaração. O CPL poderá contratar junto a outro fornecedor uma parte ou a totalidade de sua carga. Os contratos que tenham prazos de denúncia diferentes terão suas condições respeitadas.

É ainda estabelecido que se um consumidor livre optar por voltar a adquirir energia da distribuidora local deverá formalizar esta decisão com cinco anos de antecedência do início do fornecimento. A distribuidora poderá atendê-lo em prazo inferior, a seu exclusivo critério. 


\subsubsection{Fontes adicionais de receita para os geradores}

Uma possível fonte adicional de recursos para os geradores é a remuneração pela prestação de serviços ancilares ao sistema, prevista no artigo 59, dentre os quais:

- Reserva de potência operativa, em MW, disponibilizada para a regulação de freqüência do sistema e sua capacidade de partida autônoma;

- Reserva de capacidade, em MVA, disponibilizada pelos geradores, superior aos valores de referência estabelecidos nos Procedimentos de Rede do ONS, necessária para a operação do sistema de transmissão; e

- Operação dos geradores como compensadores síncronos, a regulação da tensão e os esquemas de corte de geração.

\subsubsection{Mercado de Curto Prazo}

O objetivo do Mercado de Curto Prazo é a contabilização e a liquidação de diferenças entre os montantes de energia contratados e os efetivamente consumidos ou produzidos pelos agentes. Esta atividade é realizada mensalmente, tendo como base o Preço de Liquidação de Diferenças - PLD - que é publicado antecipadamente pela CCEE. O cálculo do PLD leva em conta a otimização do uso dos recursos eletro-energéticos para atendimento das cargas do sistema e observa limites máximos e mínimos estabelecidos pela ANEEL (vide item 3.2.3).

\subsection{A regra de transição}

Durante o processo de conversão da Medida Provisória 144 na Lei 10.848, o Senado Federal incluiu o artigo 19 que permite que "excepcionalmente nos anos de 2004, 2005 e 2006, as licitações no ambiente de contratação regulada para venda de energia proveniente de empreendimentos de geração existentes poderão prever início de entrega da energia em até 5 (cinco) anos após a realização das licitações".

Esta alteração, atendendo aos anseios dos agentes geradores, ao permitir a venda de energia existente com antecedência maior do que um ano, possibilitou a obtenção de 
preços de venda mais elevados, não apenas pela distância da data de entrega (a este respeito, vide item 3.1.1), mas também por ter início de suprimento mais próximo de um cenário de equilíbrio entre oferta e demanda.

De fato, após o Racionamento, houve uma redução expressiva na demanda por energia elétrica, de forma que os Geradores viram-se em um mercado com uma sobra conjuntural de energia assegurada, reduzindo a receita destes agentes em decorrência da baixa dos preços tanto nos contratos bilaterais como no mercado Spot. A figura abaixo ilustra o cenário descrito.

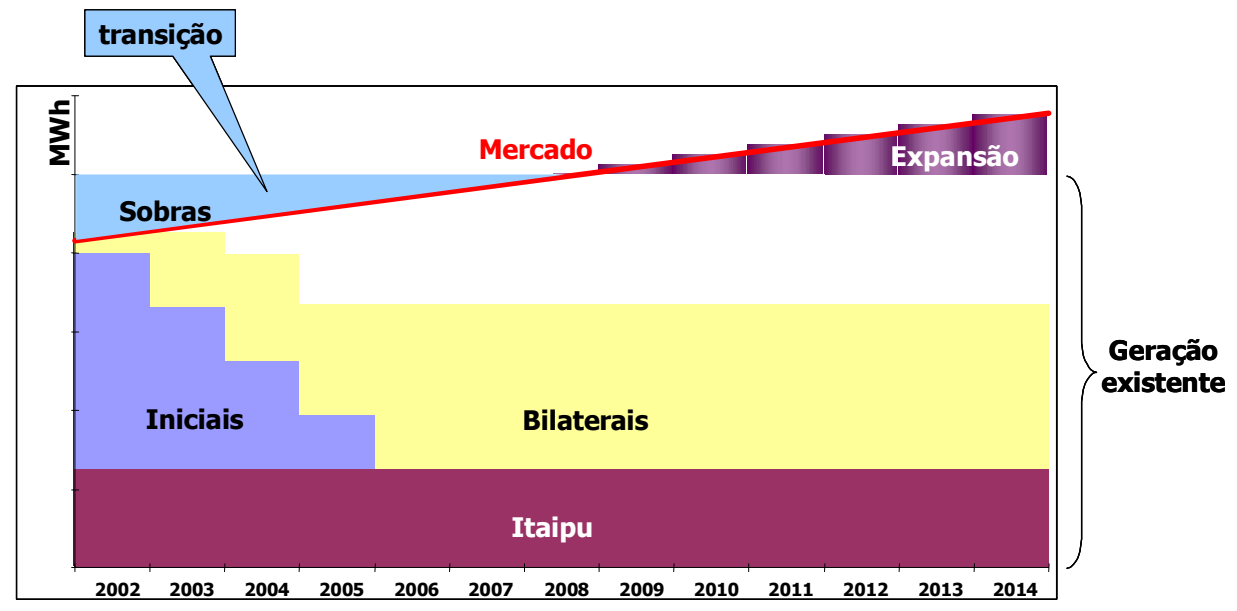

Figura 3.3 - Balanço ilustrativo de energia assegurada

\subsection{Posicionamento dos geradores}

Os geradores existentes criticam duramente a segmentação do mercado das distribuidoras, proposta no modelo em implantação. A argumentação é que a geração existente é muito heterogênea. Usinas de menor custo, seja por tratarem-se de potenciais hidrelétricos mais econômicos ou pelo fato da maior parte dos investimentos já terem sido amortizados, competirão diretamente com usinas mais caras ou oriundas de recentes processos de privatização. Isso pode afastar potenciais investidores, na medida em que os investimentos já realizados no processo de desestatização podem ficar comprometidos em função desta concorrência acirrada. 
De qualquer forma, as mudanças no Modelo Institucional do Setor Elétrico Brasileiro exigem que as geradoras adaptem-se à nova realidade comercial. Neste sentido, para que possam desenvolver adequadamente suas estratégias de comercialização de energia, faz-se necessário conhecer o mercado e, mais especificamente, seu comportamento na contratação de energia.

\subsubsection{Definição de estratégia de comercialização de energia}

A definição da estratégia de comercialização de energia de um Gerador passa pela melhor distribuição de sua energia disponível para contratação entre ambos os ambientes de comercialização, o regulado (ACR) e o livre (ACL).

Neste ponto, uma primeira importante decisão deve ser tomada: qual percentual de sua energia assegurada um Gerador deve ou pode comercializar, sem arriscar-se excessivamente, considerando a possibilidade de cenários hidrológicos desfavoráveis e conseqüente aumento de preço e baixa alocação de energia no MRE, deixando-o exposto ao mercado Spot? Para facilitar a compreensão desta questão, apresentam-se dois importantes conceitos, a saber:

- Energia Assegurada; e

- Mecanismo de Realocação de Energia (MRE).

\subsubsection{Energia Assegurada}

A energia assegurada do sistema elétrico brasileiro é a máxima produção de energia que pode ser mantida (quase) continuamente pelas usinas hidroelétricas ao longo dos anos, atendendo uma carga com as características de sazonalidade do mercado real, simulando-se a ocorrência de cada uma das milhares de possibilidades de seqüências de vazões criadas estatisticamente, admitindo um certo risco de não atendimento à carga (em determinado percentual dos anos simulados, permite-se que haja racionamento, dentro de um limite considerado aceitável para o sistema). $\mathrm{Na}$ regulamentação atual, este risco é de $5 \%$. 
Desse modo, a determinação da energia assegurada independe da geração real e está associada às condições que cada usina pode fornecer ao sistema no longo prazo, assumindo um critério específico de risco de não atendimento do mercado - déficit ("critério de garantia"). Este risco considera considerando principalmente a variabilidade hidrológica à qual a usina está submetida. Nos cálculos das energias asseguradas são desconsiderados ainda os períodos em que a usina permanece sem produzir energia por motivos de manutenções programadas e paradas de emergência.

Considera-se energia assegurada de cada usina hidroelétrica a fração da energia assegurada do sistema que lhe seja alocada, via critério de rateio regulamentado pelo Órgão Regulador. A operação cooperativa do parque gerador brasileiro foi historicamente adotada visando garantir o uso eficiente de recursos energéticos no país. Com a introdução da competição no segmento de geração de energia e o aumento do número de agentes, optou-se pela manutenção da operação centralizada das centrais geradoras hidroelétricas visando à otimização do uso dos reservatórios e à operação com mínimo custo do sistema.

Há uma importante relação entre os valores de energia assegurada e a confiabilidade de suprimento: para qualquer combinação de geradores cuja soma dos valores de energia assegurada é igual à demanda total, a confiabilidade física de suprimento deveria ser igual (ou melhor) do que o padrão estabelecido. Além da importância para a confiabilidade de suprimento e expansão eficiente, os valores de energia assegurada têm grande importância comercial, pois constituem a quantidade máxima de energia que o gerador pode comprometer (volumes médios anuais) com contratos de longo prazo.

\subsubsection{Mecanismo de Realocação de Energia - MRE}

O MRE é um mecanismo financeiro que objetiva compartilhar os riscos hidrológicos que afetam os geradores, na busca de garantir a otimização dos recursos hidrelétricos dos sistemas interligados. A intenção é garantir que todos os geradores que dele participam comercializem a Energia Assegurada que lhes foi atribuída, independente 
de sua produção real, desde que as usinas integrantes do MRE, como um todo, tenham gerado energia suficiente para tal.

Em outras palavras, por meio do MRE a energia produzida é contabilmente distribuída - ou alocada - transferindo o excedente daqueles que geraram além de sua Energia Assegurada para aqueles que geraram abaixo por imposição do despacho centralizado do sistema. [ANEEL, 2005]

\subsubsection{O montante de energia a ser comercializado}

Uma vez definido o montante de energia contratada (cada empresa geradora pode comercializar até $100 \%$ da energia assegurada que lhe for atribuída, não havendo restrição de percentual mínimo contratado), o gerador será responsável pelo suprimento deste montante, dispondo do adicional de geração conforme critério de rateio do MRE, para venda no mercado de curto prazo. Para fins de análise do processo de comercialização da energia assegurada de um gerador, apresenta-se na tabela abaixo a relação de dois agentes hipotéticos (produtores independentes) que utilizam estratégias de comercialização distintas em relação ao mercado de energia.

Tabela 3.1 - Exemplo de dois agentes hipotéticos

\begin{tabular}{|c|c|c|}
\hline \multicolumn{3}{|c|}{ Contrato de Suprimento dos Agentes Geradores } \\
\hline \multirow{2}{*}{ GERADOR } & Nível de Contratação da Energia Assegurada \\
\cline { 2 - 3 } & Contrato Bilateral & Exposição ao Preço SPOT \\
\hline Agente A & $100 \%$ & $0 \%$ \\
\hline Agente B & $\mathrm{x} \%$ & $(100-\mathrm{x}) \%$ \\
\hline
\end{tabular}

De maneira a reproduzir o caso mais geral possível, admite-se que parcela do mercado não disponha de contratação de longo prazo. O Agente A decidiu contratar toda sua energia assegurada, sendo que o Agente B reservou parcela de sua energia assegurada para venda no mercado de curto prazo. 
O Agente A, ao contratar bilateralmente $100 \%$ de sua energia assegurada, não dispõe de flexibilidade para negociar energia no curto prazo, fazendo com que sua participação nesse mercado seja restrita à eventual geração de energia secundária (alocação acima da energia assegurada, devida a afluência melhor do que a esperada).

Por outro lado, o Agente B possui maior flexibilidade, pois sua parcela de energia não comprometida em contrato, no caso mais geral possível, poderá ser utilizada de acordo com a situação representada na tabela. Esta flexibilidade permite ao Agente B vender a energia sem contrato no mercado de curto prazo, minimizando o risco de necessitar adquirir a preços elevados uma complementação de parte do seu contrato, se a energia que lhe foi alocada no momento da entrega for menor do que o total de sua energia assegurada [Ramos, Fadigas e Lima, 2000].

Em face do exposto, é de se esperar que o preço de venda de energia tenha grande aderência com a expectativa dos preços do mercado de curto prazo (preços Spot ou PLD).

\subsubsection{Aspectos a serem considerados na elaboração da estratégia}

Com os importantes conceitos acima apresentados, pode-se seguir com a apresentação dos passos para elaboração da estratégia de comercialização de energia. Uma etapa importante é o levantamento dos riscos e oportunidades inerentes a cada um dos ambientes de contratação. 


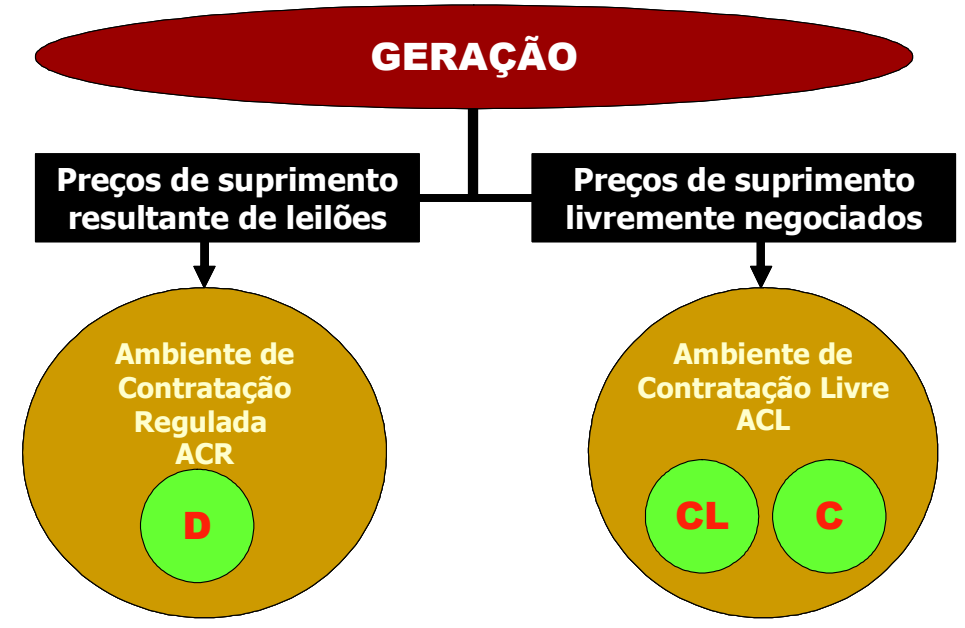

Figura 3.4 - Convivência entre mercado competitivo e regulado

Do ponto de vista qualitativo, pode-se dizer que o ACR tem como característica a possibilidade de venda de blocos maiores de energia, com condições contratuais previamente conhecidas e inflexíveis, sujeito a um risco de crédito médio das 30 distribuidoras do sistema interligado, além de concorrer exclusivamente por preço. Avaliações quantitativas envolvem conhecer quanto e em quais leilões as distribuidoras estão dispostas e são incentivadas a comprar a energia para o atendimento de seus mercados.

Por outro lado, o ACL tem como característica a venda de quantidades menores de energia, porém com cláusulas contratuais livremente negociadas entre as partes, com risco de crédito melhor e seletivo, podendo o vendedor oferecer outras vantagens competitivas como agilidade na negociação, flexibilidade de prazos e outros serviços agregados. Também são necessárias avaliações quantitativas como o volume potencial do mercado e a expectativa de tarifa dos consumidores cativos das distribuidoras, definindo a atratividade da migração dos consumidores potencialmente livres para este ambiente, estimado a partir do preço médio de compra de energia no ACR.

Intuitivamente, corroborado por Dornellas e Sant'Anna (2004), pode-se concluir que a estratégia mais inteligente envolve um equilíbrio na alocação dos montantes de energia a contratar em ambos os ambientes de comercialização. No entanto, é de 
reconhecida dificuldade definir os percentuais de contratação em cada ambiente trata-se de uma decisão complexa envolvendo diversas variáveis. Também é evidente que se trata de um processo dinâmico, onde a cada instante deve-se reavaliar o percentual de energia destinado a cada mercado, livre ou regulado.

Inobstante as dificuldades inerentes ao processo de estabelecimento de estratégias comerciais, ao contrário das Distribuidoras, que se organizam cooperativamente sob uma única associação (ABRADEE), os agentes Geradores têm grande dificuldade de coordenarem seus interesses junto aos entes governamentais, fato demonstrado pela existência de múltiplas associações de classe (ABRAGE, APINE, ABRAGET, ABRAGEF, APMPE, etc.).

Por fim, é importante conhecer o balanço entre oferta e demanda de energia elétrica presente e futuro, de forma a se definir as tendências do mercado, impactando diretamente no preço de venda.

Neste processo todo, um grande número de ferramentas de previsão de preços e de condições de despacho das usinas, de simulação das regras de mercado e dos comportamentos dos agentes, além de modelos econômico-financeiros, são utilizados. Trata-se de toda uma cadeia interdependente em que cada elo representa papel relevante no desenho da estratégia.

\subsubsection{Ferramentas utilizadas}

A ferramenta mais comumente utilizada para previsão dos preços do mercado de curto prazo é o Newave, desenvolvido pelo CEPEL. O programa apresenta os custos marginais de operação esperados para o horizonte de 5 anos, simulando a operação otimizada do sistema brasileiro.

Para a obtenção do balanço entre oferta e demanda pode-se utilizar dados públicos como os do CTEM/CCPE - Comitê Técnico para Estudos de Mercado ou dos Relatórios de Planejamento Anual da Operação Energética do ONS, de onde se 
obtêm o crescimento esperado da carga de energia; e dos relatórios de acompanhamento de obras de empreendimentos de geração elétrica, atualizados mensalmente pela ANEEL, os quais refletem a situação de cada usina, desde a sua outorga até a sua entrada em operação comercial [ANEEL, 2004].

Finalmente, para quantificar a demanda esperada em cada tipo de leilão de energia e o percentual esperado de redução dos contratos de energia existente, etapa importante da definição de estratégia, o desafio é conhecer e prever o comportamento das Distribuidoras.

Conhecer e prever o comportamento das Distribuidoras envolve muito mais do que apenas "adivinhar" sua previsão de carga; é muito importante saber como as regras de repasse, seus incentivos e suas limitações interferem na forma de declaração das necessidades de contratação para o MME, conforme previsto nos artigos 17 e 18 do Decreto 5.163/2004.

Neste sentido, um modelo de otimização da contratação das Distribuidoras, considerando as condições de contorno apresentadas nos regulamentos - leis, decretos, resoluções, portarias e etc. - é uma importante ferramenta no processo de preparação das estratégias de comercialização por parte das geradoras. Este é o foco desta Dissertação.

\subsection{Contratação das Distribuidoras: função objetivo a ser otimizada}

Deseja-se otimizar a contratação das distribuidoras nos diversos leilões disponíveis, minimizando o valor presente dos prejuízos esperados - ou maximizando o valor presente dos lucros esperados - em cada ano por conta da limitação do repasse ao consumidor do valor da aquisição da energia e das penalizações aplicadas por subcontratação ou sobrecontratação.

$$
\min z=\sum_{\text {ano }} \frac{\sum_{\text {leilão }} \text { Custo }_{\text {leião }}^{\text {ano }}-\sum_{\text {leilâo }} \text { Repasse }_{\text {leilão }}^{\text {ano }}+\text { Penalidades }^{\text {ano }}}{(1+i)^{n}}
$$


O custo de cada leilão (A-5, A-3, A-1, Mega-leilão ou Ajuste), em cada ano (2005, 2006, 2007, etc.), é dado por:

$$
\operatorname{Custo}_{\text {leilão }}^{\text {ano }}=\left(\text { VolumeInicial }_{\text {leilão }}-\sum_{\mathrm{k}=\text { iń́íi__sup rimento }}^{\text {ano }} \operatorname{Redução}_{\mathrm{k}} \cdot \text { VolumeInicial }_{\text {leilão }}\right) \operatorname{Preço}_{\text {leilão }}
$$

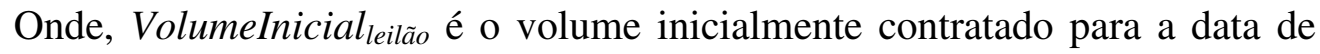
início de suprimento de cada leilão, em MWh; Redução $o_{k}$ é o percentual de redução do contrato resultante de cada leilão, caso este seja de energia existente; e Preçoleilão é o valor de compra da energia para cada leilão, em R\$/MWh.

O Repasse de cada leilão, em cada ano, é dado pelo limite imposto na regulamentação, um para cada tipo de leilão (A-5, A-3, A-1, Mega-leilão ou Ajuste).

Embora seja prevista na regulamentação a possibilidade de compra de energia pelas Distribuidoras de Geração Distribuída e de Fontes Alternativas, por tratarem-se de volumes marginais, foram desconsiderados nesta modelagem.

As Penalidades são aplicadas em cada ano por quatro possibilidades:

1. Contratação abaixo da demanda: neste caso, a Distribuidora contratou energia abaixo de seu mercado observado, estando sujeito a uma penalidade prevista nos regulamentos ${ }^{10}$, calculada no modelo pela seguinte fórmula:

$$
\text { penalização }(\text { subcontratação })=\left(\max \left\{0, P L D_{\text {sub }}-V R\right\}+f m_{\text {sub }} . V R\right) \cdot V_{\text {sub }}(4)
$$

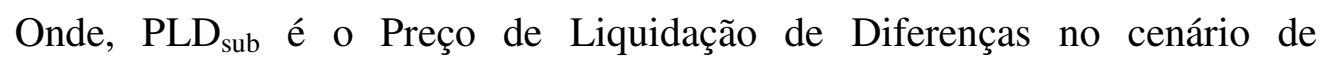
subcontratação, VR é o Valor de Referência, fm sub é um Fator de Majoração da Penalização que representa a aversão ao risco da distribuidora em estudo (quanto

\footnotetext{
${ }^{10}$ Embora a liquidação seja mensal e a penalização anual, o modelo trata simplificadamente todas as variáveis como anuais.
} 
maior este fator, maior a aversão ao risco do agente) e $\mathrm{V}_{\text {sub }}$ é o volume subcontratado.

2. Contratação acima da demanda: neste caso, a Distribuidora contratou energia acima de seu mercado observado, estando sujeita aos lucros e prejuízos decorrentes desta opção, sendo sua "penalidade" é calculada no modelo pela seguinte fórmula:

$$
\text { penalização( } \text { sobrecontratação })=\left(C M A-P L D_{\text {sobre }}\right) \cdot f m_{\text {sobre }} . V_{\text {sobre }}(5)
$$

Onde, CMA é o Custo Médio de Aquisição da Distribuidora para a energia entregue naquele ano, PLD $_{\text {sobre }}$ é o Preço de Liquidação de Diferenças no cenário de sobrecontratação, fm $_{\text {sobre }}$ é um Fator de Majoração para penalização de forma a refletir a aversão ao risco da distribuidora em estudo e $\mathrm{V}_{\text {sobre }}$ é o volume sobrecontratado acima do limite de $103 \%$ permitido pela regulamentação.

3. Recontratação ${ }^{11}$ de energia existente abaixo do Limite Inferior definido na regulamentação: nesta situação, a penalidade é dada pela seguinte fórmula:

$$
\text { penalização(recontratação_abaixo_ } L I)=(V R-V L E) . V_{\text {abaixo_LI }}(6)
$$

Onde, VR é o Valor de Referência, VLE o Valor da Energia Existente para entrega no ano em questão e $\mathrm{V}_{\text {abaixo_LI }}$ é a diferença entre o volume efetivamente recontratado e o Limite Inferior.

4. Recontratação de energia existente acima do Limite de Reposição: neste caso, a penalidade é calculada da seguinte maneira:

\footnotetext{
${ }^{11}$ A diferença entre "Contratação" e "Recontratação" está no objeto de contrato. Enquanto o primeiro abrange toda e qualquer compra de energia por parte da Distribuidora, a segunda se refere apenas ao montante de energia existente cujo contrato está expirando e que deve (ou pode) ser recontratado, nos termos do regulamento.
} 
penalização(recontratação_acima $)=(V R-V L E) . V_{\text {acima } L R}(7)$

Onde, VR é o Valor de Referência, VLE o Valor da Energia Existente para entrega no ano em questão e $\mathrm{V}_{\text {acima_LR }}$ é a diferença entre o volume efetivamente recontratado e o Limite de Reposição. 


\section{ALGORITMOS GENÉTICOS}

Para proceder à solução otimizada do problema relativo à contratação de energia por parte dos Agentes Distribuidores, visando emular seu comportamento, optou-se pela utilização de Algoritmos Genéticos, tendo em vista a vocação natural desse tipo de algoritmo para tratar problemas não lineares, como também devido à sua facilidade de implementação.

\subsection{Introdução a métodos de otimização}

Problemas de otimização são encontrados nos mais diversos campos da vida humana, desde decisões corriqueiras como o melhor caminho a se percorrer entre dois pontos, até decisões mais complexas como o ponto ótimo de aquecimento de determinado material para melhor aproveitamento de suas características físicas.

Também na Engenharia Elétrica diferentes problemas de otimização, com os mais diversos níveis de complexidade, são encontrados, lançando-se mão, em cada caso, de diferentes técnicas de solução.

A formulação de um problema de otimização qualquer envolve a composição de uma função objetivo, que relacione as diferentes variáveis consideradas, bem como as restrições impostas a cada uma. Otimizar a solução de um determinado problema consiste em identificar a alternativa viável, ou os respectivos valores para as variáveis consideradas, que maximize ou minimize o valor da função objetivo, conforme a natureza do problema, de forma que nenhuma outra solução atribua um valor maior ou menor à função, respectivamente, respeitada as restrições do problema [Bento, 2004].

Dificuldades podem surgir na otimização da solução de problemas reais, tais como grande número de variáveis, elevado número de restrições, ruídos, não-linearidades, descontinuidades, objetivos conflitantes ou representados por funções complexas. De acordo com o problema abordado, muitas vezes um processo de otimização não é 
capaz de identificar um máximo global para o problema, mas o simples fato de se determinar uma solução viável melhor que uma já conhecida, pode ser considerado um grande resultado [Bäck et alt, 1991 apud Bento, 2004].

Existem muitos métodos de otimização e cada um deles alcança melhor resultado em determinados tipos de problemas. A escolha do método depende de uma série de características do problema a ser otimizado, principalmente do comportamento da função que o representa, a qual muitas vezes é de difícil determinação. Faz-se necessário também um bom conhecimento das ferramentas de otimização.

De acordo com as características dos problemas, podem-se classificar as ferramentas de otimização em dois grandes grupos: programação linear e programação nãolinear.

A programação linear (PL) tem como objetivo obter a solução ótima de problemas que sejam perfeitamente representados por um conjunto de equações lineares. $\mathrm{O}$ propósito da PL é minimizar ou maximizar uma função linear, chamada função objetivo, respeitando-se um sistema linear de equações denominadas restrições.

As técnicas para programação não-linear podem ser subdividias em três subgrupos:

1. Métodos determinísticos, baseados no cálculo de derivadas, ou em aproximações destas. Necessitam, portanto, de alguma informação do vetor gradiente, seja procurando o ponto onde ele se anula ou usando a direção para a qual aponta.

2. Métodos estocásticos, utilizam um conjunto de ações que buscam o ótimo de maneira "aleatória orientada", sem necessitar de qualquer informação de derivadas ou sobre o comportamento do problema.

3. Métodos enumerativos, dos quais se destaca a Programação Dinâmica, fazem uma varredura completa (busca exaustiva) de todas as possíveis soluções. Isto implica num tempo excessivo de cálculo na maior partes dos problemas. [Ávila et alt, 2003]. 
Segundo Soares (1997), sendo o problema complexo (por exemplo, com muitas variáveis, descontínuo ou de difícil derivação) e necessitando-se da solução global em um tempo computacional razoável, as técnicas estocásticas são as mais indicadas.

\subsubsection{Métodos estocásticos}

Os métodos estocásticos têm como principal característica a busca pelo ótimo através de regras de probabilidade, trabalhando de maneira "aleatória orientada". Tais métodos utilizam apenas as informações contidas na função de otimização, não requerendo informações sobre suas derivadas ou possíveis descontinuidades [Ávila et alt, 2003].

\subsubsection{Métodos naturais}

Os métodos naturais são processos numéricos e estocásticos que simulam determinados fenômenos encontrados na natureza, na busca de uma solução otimizada de sistemas. Entre os métodos naturais, destacam-se o Recozimento Simulado e a Computação Evolutiva.

Enquanto o Recozimento Simulado baseia-se no processo físico de recozimento de um sólido, fazendo-se a busca do ótimo a partir de um dado ponto inicial [Ávila et alt, 2003], o termo Computação Evolutiva representa uma generalização das técnicas de otimização que empregam os princípios funcionais dos processos evolutivos biológicos. Sua característica fundamental é a codificação de soluções representadas por diferentes indivíduos, contidos em uma população ou um conjunto de soluções. Além disso, emprega métodos de recombinação, variações aleatórias, competição e seleção de soluções, na busca pela solução otimizada de um problema.

Segundo Bäck, Hammel e Schwefel (1997) apud Bento (2004), a principal vantagem da Computação Evolutiva sobre os outros métodos de otimização reside na grande flexibilidade e adaptabilidade aos problemas reais, combinando robustez e pesquisa abrangente das soluções. Mais do que um conjunto de procedimentos prontos para 
uso em aplicações pré-definidas, a Computação Evolutiva representa um conceito genérico, que pode ser aplicado para a resolução de problemas complexos de otimização.

Outros aspectos positivos da Computação Evolutiva devem ser mencionados. Estas técnicas trabalham com a modelagem real do problema, sem necessidade de informações auxiliares, como derivadas, ou aproximações quaisquer. Desta forma, estes métodos conciliam robustez e simplicidade na implementação, trazendo maior rapidez na resolução de problemas com múltiplos objetivos e com grande número de restrições. Dentre os diversos métodos da Computação Evolutiva, destacam-se os Algoritmos Genéticos.

\subsection{Algoritmos Genéticos}

Algoritmos Genéticos (AG's) são métodos computacionais que simulam o comportamento evolucionário das espécies, baseados na teoria Darwiniana, cujo objetivo é a otimização de uma dada função objetivo. Foram propostos em 1975 por John Holland e desde então têm sido aplicados em diversos problemas da engenharia.

O Algoritmo Genético utilizado nesta dissertação é conhecido como Algoritmo Genético Simples (AGS). Um AGS compreende um conjunto de indivíduos (população) e um conjunto de operadores genéticos que atua sobre a população. De acordo com a teoria da evolução, somente os indivíduos mais capazes de uma população sobrevivem, gerando descendentes. Analogamente, o AGS analisa um conjunto de soluções potenciais devidamente codificado (neste caso, codificação binária, ou seja, os indivíduos são strings de bits), que constitui a população. O AGS então manipula os indivíduos mais aptos, utilizando-se dois operadores genéticos, para a obtenção de uma população otimizada [Dornellas, 1997].

Dentre as vantagens da utilização dos Algoritmos Genéticos, destacam-se a facilidade de implementação computacional, a inexistência de restrições quanto ao tipo do problema (ou seja, a função objetivo pode ser discreta, não contínua, não 
convexa) e a possibilidade de se integrar o algoritmo com aplicativos externos que calculem a função objetivo (isto significa que para o Algoritmo Genético a função objetivo pode ser uma caixa preta).

As principais desvantagens no uso deste método são o esforço computacional necessário para se avaliar os diversos indivíduos a cada geração e a falta de garantia quanto ao alcance da solução ótima - pode-se obter um ótimo local, ou ainda, uma solução muito boa, mas que não se garante ser a ótima.

Muitos trabalhos têm sido desenvolvidos com a utilização de algoritmos genéticos na Engenharia, destacando-se trabalhos recentes como Otimização do sistema de coleta de resíduos de biomassa de madeira para fins energéticos [Risso, 2002], Algoritmos genéticos e suas variantes na solução de problemas de minimização de perdas em redes de distribuição [Bento, 2004] e Sintonia de controladores PID por algoritmos genéticos [Galvão Júnior, 2004].

\subsubsection{Terminologia}

Como o método de otimização em Algoritmos Genéticos baseia-se em uma teoria biológica, algumas equivalências entre o mundo biológico e a programação computacional são feitas:

- Genes: cada um dos elementos do cromossomo, representado por bits;

- Cromossomo ou string: conjunto de genes que representam os valores das variáveis do problema. A representação pode ser binária (como no exemplo abaixo), inteira, real, etc.;

- Indivíduo: conjunto de cromossomos que formam uma solução candidata, ao qual é associado um valor da função de avaliação;

- Geração: conjunto de indivíduos testados paralelamente a partir dos quais, em função de sua aptidão (ou fitness) serão gerados descendentes.

A figura abaixo ilustra o exemplo em que se deseja modelar um problema com duas variáveis de três bits cada. 


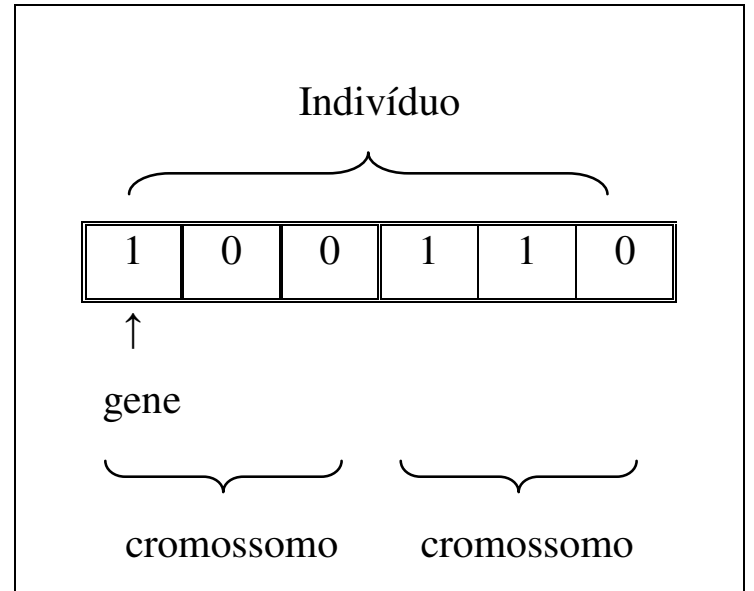

Figura 4.1 - Exemplo de indivíduo modelado para Algoritmos Genéticos

\subsubsection{Algoritmo básico}

O fluxograma básico de um Algoritmo Genético está ilustrado na figura a seguir [Kagan e Oliveira, 2003].

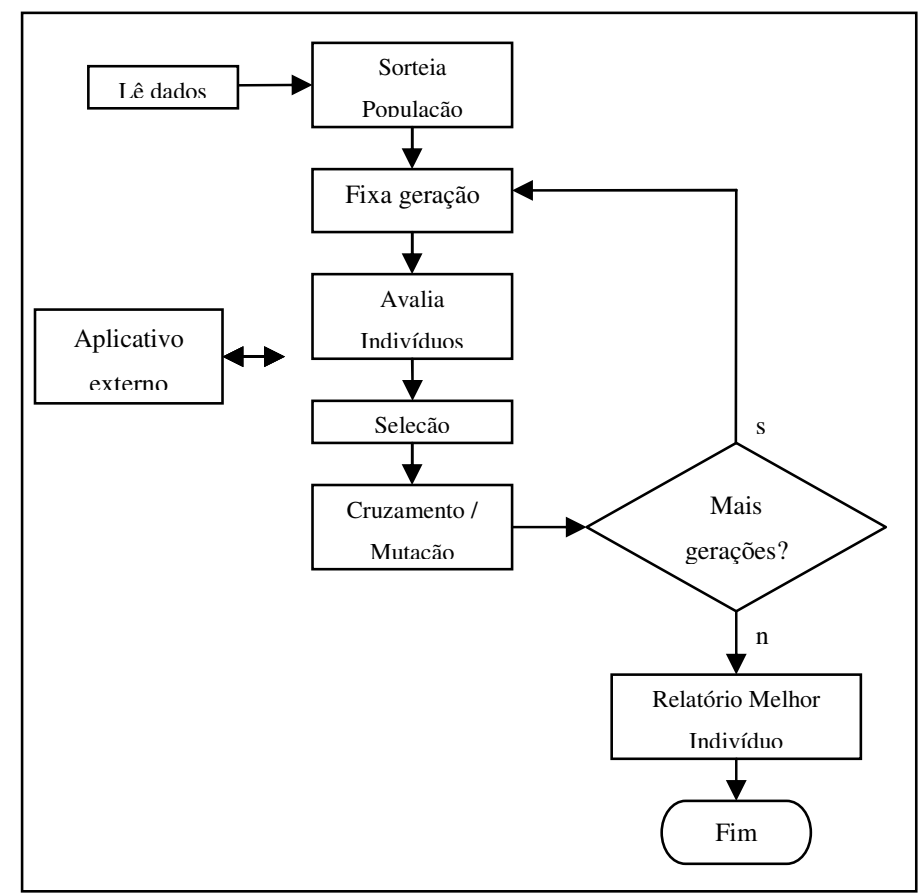

Figura 4.2 - Algoritmo genético básico 
O sorteio da população inicial é feito através da geração de números aleatórios de probabilidade uniforme, de tal forma que, para cada bit, se o valor sorteado for menor do que 0,5 o bit será 0 , caso contrário será 1 .

A avaliação dos indivíduos de cada geração é feita pela função de avaliação definida a priori. Para o processo de seleção, deve-se normalizar a função de avaliação de forma a associar o resultado da função de avaliação a uma probabilidade de ser selecionado para o processo de cruzamento.

Antes de proceder à seleção, deve-se fazer o escalamento da função de avaliação ou de aptidão ${ }^{12}$. No começo da execução do AG é comum a existência de poucos indivíduos extraordinários em uma população com colegas medíocres. Quando se utiliza o método de seleção proporcional (roleta, conforme explicado mais adiante), os indivíduos extraordinários ocuparão uma grande fatia do círculo, conduzindo a uma convergência prematura.

Durante a execução, pode ainda existir uma diversidade significativa dentro da população; entretanto, o valor médio de aptidão da população pode estar próximo do melhor valor de aptidão da população. Se esta situação não é controlada, membros médios e melhores membros produzem o mesmo número de cópias em futuras gerações e a sobrevivência do mais apto, necessária para o aperfeiçoamento, torna-se uma caminhada aleatória entre os medíocres. Em ambos os casos, o escalamento pode ajudar [Dornellas, 1997].

O escalamento utilizado neste trabalho é o escalamento linear, determinando uma relação linear entre o valor de aptidão original e o valor de aptidão escalado. $\mathrm{O}$ algoritmo de escalamento, onde se obtém uma relação linear entre a função de mérito original (f.m.) e a função de mérito escalada (f.m.') foi assim descrito por Dornellas (1997):

\footnotetext{
${ }^{12}$ Conforme se verá no item 4.2.3.2, a função de avaliação determina a aptidão de cada indivíduo em perpetuar seus genes nas próximas gerações. Quando se deseja maximizar uma dada função objetivo, essa mesma função pode ser a função de avaliação.
} 


$$
\begin{aligned}
& \text { Se f.m.mínimo }>(C * f . m \cdot \text { médio }-f . m \cdot \text { máximo }) /(C-1) \text { então } \\
& \text { delta }=f . m \cdot \text { máximo }-f . m \cdot \text { médio } \\
& a=(C-1) * f . m \cdot \text { médio } / \text { delta } \\
& b=f . m \cdot \text { médio } *(f . m \cdot \text { máximo }-C * f . m \cdot \text { médio }) / \text { delta }
\end{aligned}
$$

Señ̃o

$$
\begin{aligned}
& \text { delta }=f . m \cdot \text { médio }-f . m \cdot \text { mínimo } \\
& a=f . m \cdot \text { médio } / \text { delta } \\
& b=-f . m \cdot \text { mínimo } * \text { f.m.médio } / \text { delta }
\end{aligned}
$$

Fim se

f.m.' $=a^{*} f . m .+b$

Figura 4.3 - Algoritmo de escalamento linear

Onde:

f.m.mínimo é o menor valor de função de mérito dos indivíduos da geração;

f.m.médio é o valor médio da função de mérito dos indivíduos da geração, calculado como:

$$
\text { Mérito }_{\text {médio }}=\frac{1}{\text { Indivíduos }^{\text {Indivíduos }}} \sum_{i=1}^{\text {Mérito }_{i}}
$$

f.m.máximo é o maior valor de função de mérito dos indivíduos da geração; e $C$ é um coeficiente definido arbitrariamente, o qual define que o valor máximo da função de avaliação escalada deve ser $C$ vezes maior que o valor médio.

Assim, por exemplo, se um indivíduo genérico tiver uma função de aptidão original $f m$, então para efeito de seleção, sua função de aptidão será dada por $f m^{\prime}=a \cdot f m+b$, conforme a figura abaixo: 


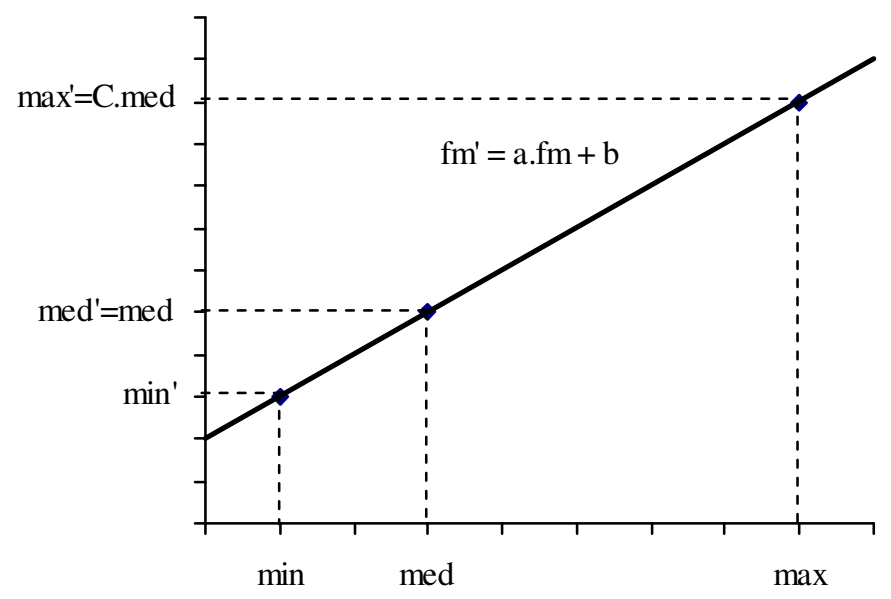

Figura 4.4 - Escalamento linear

Neste algoritmo, os coeficientes a e b são escolhidos de tal maneira a se garantir que o mérito médio mantenha-se constante, pois se deseja que a população média tenha a mesma probabilidade de perpetuação.

Para controlar o número de descendentes do melhor indivíduo da população, a outra relação para obtenção dos coeficientes a e b é que o valor máximo da função de avaliação escalada seja $C$ vezes maior que o valor médio. Valores típicos para este parâmetro são de 1,2 a 2,0.

Agora sim se passa ao processo de seleção. Ele pode ser feito de várias formas e, no caso do Algoritmo Genético Simples, é feito da através do método da roleta. O método da roleta consiste em associar a cada cromossomo um pedaço da roleta (ou setor) de tamanho proporcional à sua função de avaliação. A seleção é feita da seguinte forma:

1) Sorteia-se um número entre 0 e a soma das funções de avaliação

2) Soma-se, em qualquer ordem, o valor do setor alocado de cada cromossomo

3) O cromossomo cujo setor fizer esta soma ultrapassar o número sorteado será o cromossomo escolhido 
A figura abaixo ilustra o método descrito:

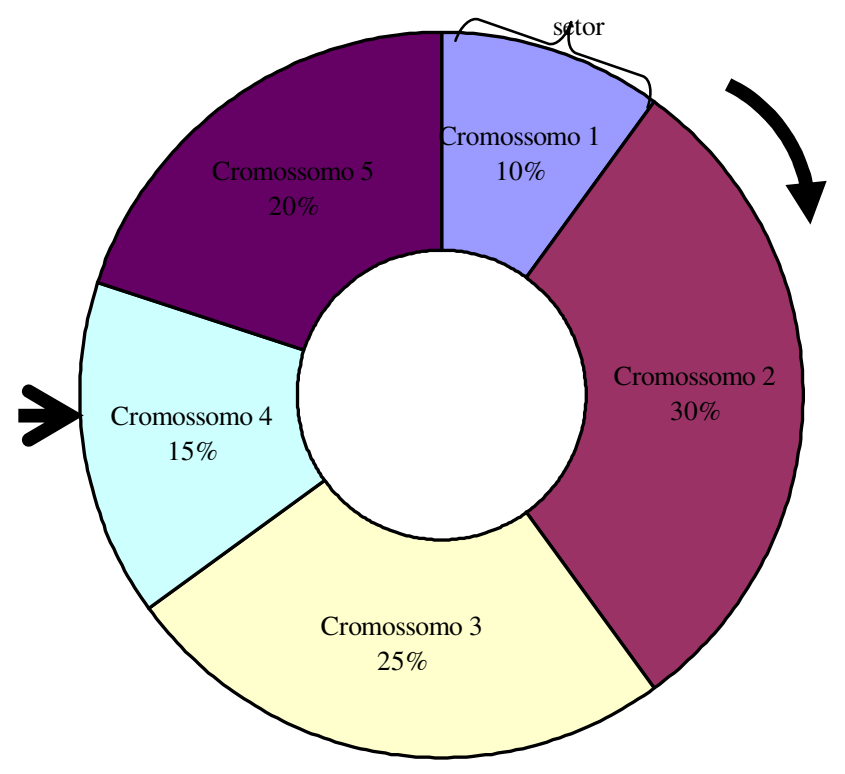

Figura 4.5 - Roleta

Durante a seleção, por se tratar de um processo probabilístico, pode ocorrer a perda do melhor indivíduo daquela geração, isto é, pode acontecer de o indivíduo mais apto não ser escolhido para formar a geração seguinte. Para solucionar esta questão existe o processo de Elitismo, no qual os $n$ melhores indivíduos da geração atual são copiados na geração seguinte.

Uma vez selecionados os indivíduos, a etapa seguinte é a do cruzamento. Primeiro, sorteia-se um número de 0 a 1 e, caso o valor sorteado seja menor que a taxa de cruzamento, procede-se o referido processo; caso contrário, apenas repetem-se os cromossomos dos "pais” para a próxima geração.

O processo de cruzamento pode ser feito em único ponto e múltiplos pontos. Significa dizer que o ponto de corte dos pais para a formação dos novos indivíduos pode ser único ou múltiplo. 
Para o processo de cruzamento de um ponto, utilizado neste trabalho, sorteia-se um número $n$ entre 1 e o tamanho do string, de tal forma que um dos filhos terá os genes de 1 a $n$ de um dos pais e de $n+1$ até o final do outro. Analogamente, o outro filho receberá os $n$ primeiros genes do segundo pai e os demais genes do primeiro, conforme ilustrado abaixo:

Pais

Filhos

\begin{tabular}{|c|c|c|c|c|c|c|c|c|c|c|c|c|c|c|c|c|}
\hline ) & 0 & 1 & 1 & 0 & 1 & 1 & 1 & & 0 & 0 & 1 & 1 & 1 & 0 & 1 & 1 \\
\hline \multicolumn{8}{|c|}{$\uparrow \quad$ Posição sorteada } & \multicolumn{9}{|c|}{$\Rightarrow>$} \\
\hline 1 & 0 & 0 & 1 & 1 & 0 & 1 & 1 & & 1 & 0 & 0 & 1 & 0 & 1 & & \\
\hline
\end{tabular}

Figura 4.6 - Processo de cruzamento de um ponto

Apenas de forma ilustrativa, segue um exemplo de cruzamento de dois pontos:

Pais

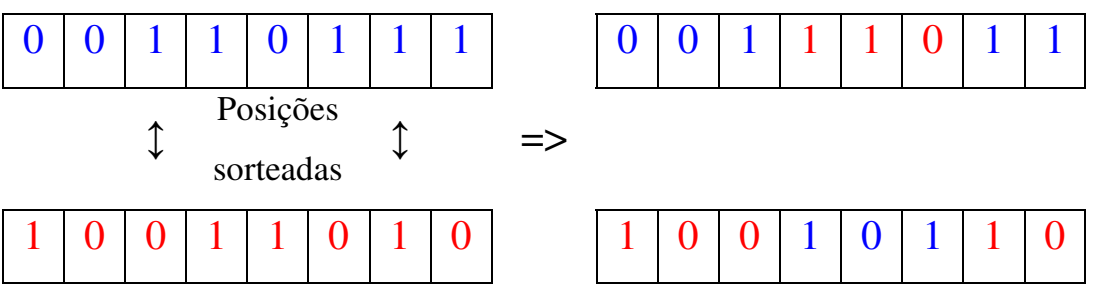

Figura 4.7 - Processo de cruzamento de dois pontos

Um dos operadores mais importantes no processo de evolução das espécies é a mutação. É a partir deste mecanismo que saltos qualitativos na população podem ser verificados. Para executar tal processo, para cada gene (bit) de toda a população sorteia-se um número de 0 a 1 e, caso o número sorteado seja menor do que a taxa de mutação definida, faz-se a troca do valor daquele bit, de forma que se era 0 passa a ser 1 e vice-versa. O processo pode ser assim ilustrado:

Original

Mutação

\begin{tabular}{|l|l|l|l|l|l|l|l|}
\hline 0 & $\mathbf{0}$ & 1 & 1 & 0 & 1 & 1 & 1 \\
\hline & \multicolumn{1}{|c|}{ Posição sorteada }
\end{tabular}$=$\begin{tabular}{|l|l|l|l|l|l|l|l|}
\hline 0 & $\mathbf{1}$ & 1 & 1 & 0 & 1 & 1 & 1 \\
\hline
\end{tabular}

Figura 4.8 - Processo de mutação 
Valores muito baixos de mutação levam à estagnação da população, enquanto valores muito elevados levam a populações "instáveis".

\subsubsection{Passos para implementação de um AG}

Os passos para implementação de um Algoritmo Genético são:

1. Codificação do problema

2. Definição da Função de Avaliação

3. Definição dos parâmetros do Algoritmo Genético

4. Definição do critério de parada

\subsubsection{Codificação do problema}

A codificação do problema consiste em transformar as variáveis de decisão do problema em um cromossomo, podendo ser binária, inteira, real, etc., tendo a primeira sido utilizada neste trabalho.

A codificação binária nada mais é do que a "tradução" de valores (posição de chaves em um circuito, o despacho de usinas em um sistema ou o volume de energia a ser contratado) em números binários. Como exemplo, seja a rede abaixo, onde se deseja codificar a posição de três chaves:

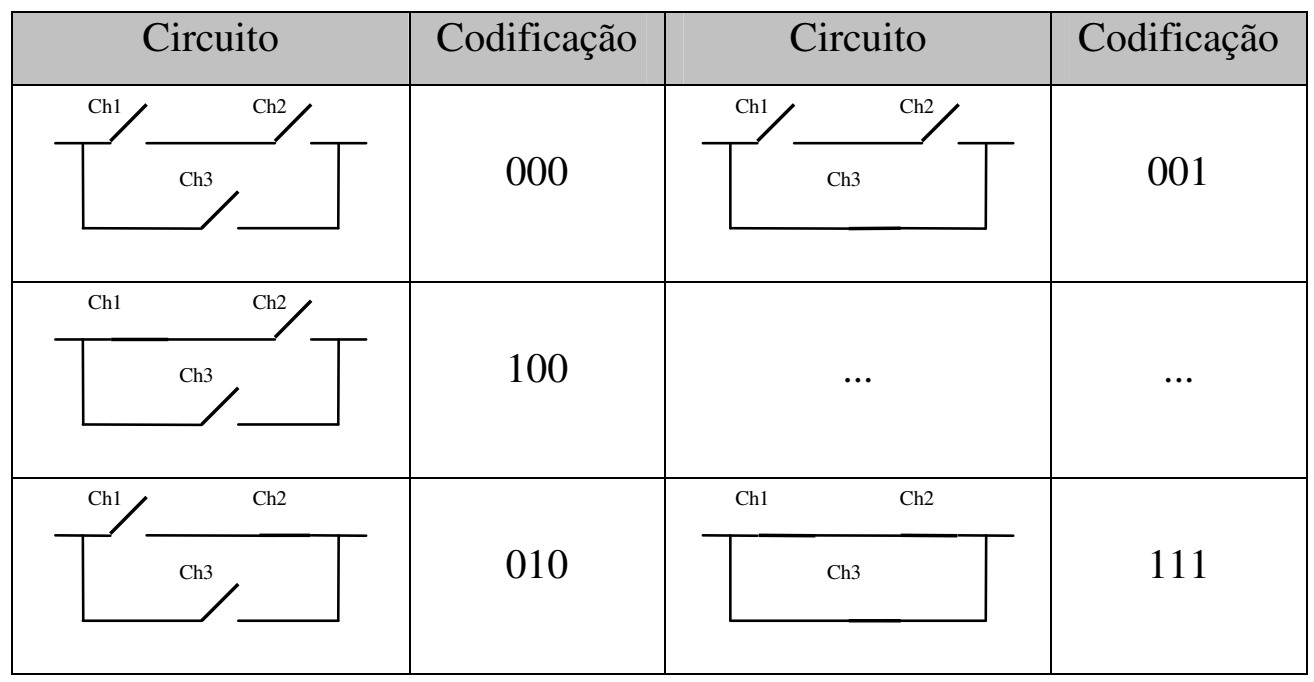

Figura 4.9 - Exemplo de codificação binária de problema 
No caso deste trabalho, a codificação binária utilizada foi a Gray. Números binários Gray têm a característica de terem sempre a distância de um bit dos números subsequientes. A escolha do binário Gray deu-se a partir de simulações de casos comparativos, obtendo-se resultados melhores e em menor número de gerações em relação ao binário convencional. A formação do código Gray é feita da seguinte forma:

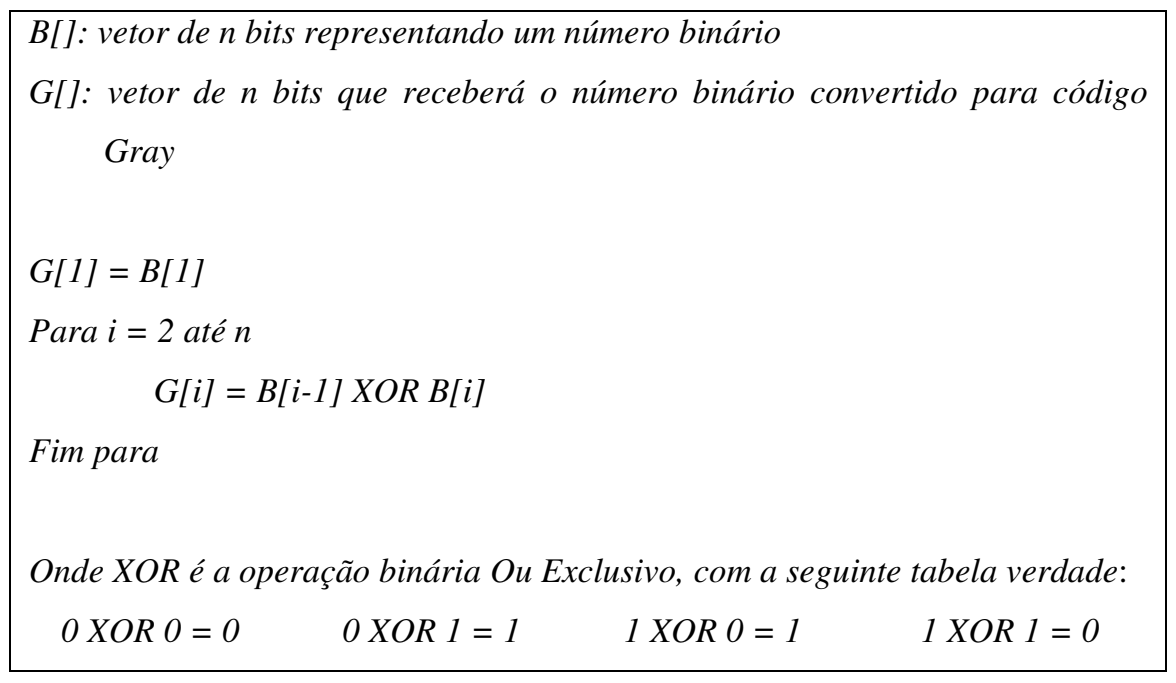

Figura 4.10 - Regra de formação do binário Gray

A tabela abaixo ilustra a diferença entre a codificação binária convencional e a Gray.

Tabela 4.1 - Diferença entre codificação binária convencional e a Gray

\begin{tabular}{|c|c|c|}
\hline Decimal & Binário Convencional & Binário Gray \\
\hline 0 & 000 & 000 \\
\hline 1 & 001 & 001 \\
\hline 2 & 010 & 011 \\
\hline 3 & 011 & 010 \\
\hline 4 & 100 & 110 \\
\hline 5 & 101 & 111 \\
\hline 6 & 110 & 101 \\
\hline 7 & 111 & 100 \\
\hline
\end{tabular}




\subsubsection{Definição da função de avaliação}

A Função de Avaliação determina a aptidão de cada indivíduo em perpetuar seus genes nas próximas gerações - o processo de seleção natural. Quando se deseja maximizar uma dada função objetivo, essa mesma função pode ser a função de avaliação.

Quando o problema envolve restrições, deve-se agregar à função de avaliação multiplicadores de Lagrange para penalizar o não atendimento das restrições.

\subsubsection{Definição dos parâmetros do $A G$}

Os parâmetros mais importantes de um Algoritmo Genético são:

- Tamanho da população: este parâmetro afeta diretamente o desempenho do algoritmo. Populações muito pequenas podem levar ao total fracasso do algoritmo; por outro lado, populações grandes demais podem deixá-lo excessivamente lento. Valores típicos variam de 30 a 100 indivíduos por geração.

- Taxa de cruzamento: nem todos os indivíduos selecionados para cruzamento passarão por este processo; alguns indivíduos podem ter simplesmente seus cromossomos copiados para a próxima geração. Este parâmetro define qual a probabilidade de ocorrer cruzamento e seu valor fica geralmente entre 0,6 e 0,95 .

- Taxa de mutação: a mutação é um processo muito importante na evolução das espécies; é a partir dele que se garantem "saltos" qualitativos de uma geração para outra, tirando a solução de uma região de mínimo (ou máximo) local. Valores típicos variam de 0,001 a 0,01 . 


\subsubsection{Critério de parada}

Para o encerramento da execução, pode-se considerar como critério de parada a convergência do problema (por exemplo, está há $n$ gerações sem saltos qualitativos ou o melhor indivíduo é apenas $x \%$ melhor que a média dos indivíduos) ou um número fixo de gerações (por exemplo, 500). 


\section{MODELO DE OTIMIZAÇÃO DA CONTRATAÇÃO DAS DISTRIBUIDORAS}

A otimização da contratação das distribuidoras, seguindo a modelagem descrita no capítulo anterior, é realizada através da utilização de algoritmos genéticos. Aqui, apresentam-se os detalhes do modelo desenvolvido.

\subsection{Entradas e saídas do modelo}

As entradas do modelo podem ser divididas em quatro grandes grupos:

1) Preços: devem-se determinar os preços esperados em $\mathrm{R} \$ / \mathrm{MWh}$, nos diferentes tipos de leilões, para entrega nos anos indicados, conforme figura abaixo.

\begin{tabular}{|c|c|c|c|c|c|c|c|c|c|c|c|c|c|}
\hline & 2005 & 2006 & 2007 & 2008 & 2009 & 2010 & 2011 & 2012 & 2013 & 2014 & 2015 & 2016 & 2017 \\
\hline A-5 & & & & & 95,00 & 95,00 & 95,00 & 95,00 & 95,00 & 95,00 & 95,00 & 95,00 & 95,00 \\
\hline $\mathrm{A}-3$ & & & 95,00 & 95,00 & 100,00 & 100,00 & 100,00 & 100,00 & 100,00 & 100,00 & 100,00 & 100,00 & 100,00 \\
\hline VR & 65,00 & 70,00 & 95,00 & 95,00 & 96,00 & 96,00 & 96,00 & 96,00 & 96,00 & 96,00 & 96,00 & 96,00 & 96,00 \\
\hline$A-1$ & 55,00 & 65,00 & 75,00 & 85,00 & 90,00 & 90,00 & 90,00 & 90,00 & 90,00 & 90,00 & 90,00 & 90,00 & 90,00 \\
\hline Mega-leilão & 65,00 & 70,00 & 75,00 & 85,00 & 95,00 & & & & & & & & \\
\hline PLD Sub & 100,00 & 100,00 & 100,00 & 100,00 & 200,00 & 200,00 & 200,00 & 200,00 & 200,00 & 200,00 & 200,00 & 200,00 & 200,00 \\
\hline PLD Sobre & 20,00 & 20,00 & 20,00 & 20,00 & 20,00 & 20,00 & 20,00 & 20,00 & 20,00 & 20,00 & 20,00 & 20,00 & 20,00 \\
\hline
\end{tabular}

Figura 5.1 - Entrada dos preços do modelo

Antes de passar à explanação de cada uma das linhas da figura acima, vale uma observação a respeito da obtenção desta curva de preços futuros.

A curva de preços futuros de energia é, sem dúvida, uma das informações estratégicas mais importantes para um agente vendedor. Ela reflete sua expectativa com relação ao equilíbrio entre oferta e demanda, às condições hidrológicas e a outras variáveis que interferem direta e indiretamente na formação dos preços.

Segundo Umbria (2001), o preço da energia dos contratos bilaterais é determinado a partir da data de seu início de suprimento e de sua duração, sendo que os contratos de menor duração devem conter um maior reflexo do 
preço de liquidação de diferenças (PLD) e os contratos de longo prazo têm seu preço estabelecido a partir do custo marginal de expansão (CME). A relação entre os preços dos contratos bilaterais, sua duração, seu início de suprimento, o PLD e o CME pode ser simplificadamente ilustrada na matriz abaixo:

Tabela 5.1 - Matriz ilustrativa da influência do PLD e do CME

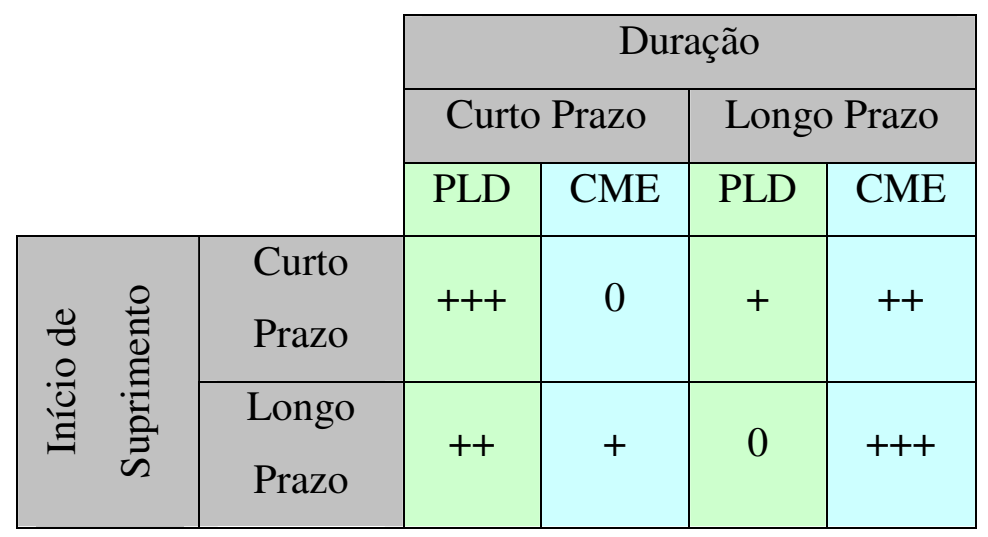

A estimativa de PLD é feita a partir da utilização de aplicativos de simulação e otimização da operação do sistema hidrotérmico brasileiro, tais como Newave, MODDHT e SDDP. Estes modelos utilizam como dados de entrada a carga prevista, as usinas em operação, as novas usinas a serem incorporadas ao parque gerador e as eventuais expansões de usinas existentes, além dos limites de intercâmbio entre os subsistemas e os custos de déficit.

A metodologia sugerida por Umbria (2001) para a definição da tendência dos preços futuros de energia - Custo Marginal de Expansão (CME) - consiste basicamente na determinação dos preços da energia nova, os quais são obtidos a partir do fluxo de caixa de cada um dos aproveitamentos considerados na base de dados disponibilizada pela ANEEL. Os preços resultantes dos fluxos de caixa são submetidos a uma ponderação de seus valores relativamente aos respectivos montantes de energia a serem agregados ao sistema, com cada um dos conjuntos de usinas cuja data de entrada em operação ocorre em um mesmo ano. Desta forma são obtidos os preços médios anuais da energia nova. 
Vale salientar que usinas termelétricas e hidroelétricas possuem características distintas quanto ao tempo requerido para sua construção (menores para térmicas), custos de instalação e custos de operação e manutenção (menores para hidráulicas). Então, considera-se para A-3 tempo típico para construção de uma termelétrica - preços maiores e, para A5 - tempo típico para construção de uma hidrelétrica - preços menores.

Desta forma, seguem as descrições de cada um dos preços indicados na Figura 5.1:

- A-5: Leilões de energia nova, para entrega cinco anos após a licitação, preços obtidos a partir da expectativa dos custos marginais de expansão para usinas hidrelétricas (obras de duração típica de 5 anos);

- A-3: Leilões de energia nova, para entrega três anos após a licitação preços obtidos a partir da expectativa dos custos marginais de expansão para usinas termelétricas (obras de duração típica de 3 anos);

- VR: Valor Anual de Referência, obtido através de uma ponderação entre o valor esperado de A-5 e de A-3, refletindo o Custo Marginal de Expansão do Sistema;

- A-1: Leilões de energia existente, para entrega um ano após a licitação, preços obtidos a partir da expectativa da média dos custos marginais de operação durante o período de duração dos contratos, considerados de 5 anos no modelo;

- Ajuste: Leilões de energia existente, para entrega no mesmo ano da licitação e com duração considerada no modelo de um ano, preços obtidos a partir da expectativa do custo marginal de operação médio daqueles anos; 
- Mega-leilão ${ }^{13}$ : Leilões de energia existente, realizados em 2004 e 2005, para entrega em 2005, 2006, 2007 (duração considerada de 8 anos) e 2008 e 2009 (duração considerada inicialmente de 5 anos e, após divulgação do edital do segundo leilão de energia existente, de 8 anos), preços obtidos a partir da expectativa da média dos custos marginais de operação no período de duração do contrato.

- PLD Sub: Percentil do Custo Marginal de Operação esperado que represente o risco de a distribuidora encontrar-se subcontratada e o Preço de Liquidação de Diferenças estar em patamar elevado;

- PLD Sobre: Percentil do Custo Marginal de Operação esperado que represente o risco de a distribuidora encontrar-se sobre-contratada e o Preço de Liquidação de Diferenças estar em patamar reduzido ${ }^{14}$;

2) Cenário: definem-se os dados do mercado simulado, em MW-médios, conforme figura e explanação que se seguem:

\begin{tabular}{|c|c|c|c|c|c|c|c|c|c|c|c|}
\hline & 2005 & 2006 & 2007 & 2008 & 2009 & 2010 & 2011 & 2012 & 2013 & 2014 & 2015 \\
\hline \multicolumn{2}{|c|}{ Crescimento estimado } & $3,0 \%$ & $2,5 \%$ & $2,5 \%$ & $2,5 \%$ & $2,5 \%$ & $2,5 \%$ & $2,5 \%$ & $2,5 \%$ & $2,5 \%$ & $2,5 \%$ \\
\hline Demanda & 2.550 & 2.627 & 2.692 & 2.759 & 2.828 & 2.899 & 2.972 & 3.046 & 3.122 & 3.200 & 3.280 \\
\hline Contratos Existentes & 1.558 & 1.166 & 1.302 & 1.298 & 1.294 & 1.290 & 1.286 & 1.282 & 1.279 & 1.255 & 1.255 \\
\hline
\end{tabular}

Figura 5.2 - Dados de Cenário

- Crescimento estimado: Percentual do crescimento esperado do mercado em relação ao ano anterior, valores obtidos a partir de estudos de mercado das Distribuidoras ou de órgãos de planejamento;

${ }^{13}$ O Mega-leilão de energia existente foi criado para facilitar a transição entre os modelos, sendo realizado em duas etapas - a primeira em 07/12/2004 (para venda de energia com entrega em 2005, 2006 e 2007) e a segunda em 02/04/2005 (para venda de energia com entrega em 2008 e 2009). Apesar de serem eventos pontuais, que não se repetirão, foram incluídos no modelo para testar sua potencialidade.

${ }^{14}$ A tomada de decisão pela média é, no caso do sistema brasileiro, desaconselhável, uma vez que os preços spot ficam muito tempo próximos do piso e em poucos momentos, mas suficientes para comprometer o desempenho dos agentes, em patamares elevados. Desta forma, ao invés de se utilizar toda uma distribuição de probabilidades, o modelo, de forma simplificada, utiliza apenas os percentis representativos dos casos extremos (por exemplo, $5 \%$ e $95 \%$ ). 
- Demanda: Definindo-se o ponto de partida do mercado (2005), obtém-se o mercado esperado a partir das taxas de crescimento preenchidas no item anterior. Alternativamente, pode-se informar ao modelo diretamente o tamanho do mercado esperado; e

- Contratos Existentes: Montante atualmente já contratado pela Distribuidora que, juntamente com os contratos definidos pelo modelo, comporão sua carteira de contratos. Apesar de o modelo setorial permitir contratação apenas através de leilões, esses valores podem oscilar ao longo do tempo para mais em função de contratos assinados antes da publicação da MP 144 com início de suprimento no horizonte de estudo (por exemplo, aquisição de energia de usinas novas que ainda não entraram em operação) e para menos em função do término dos contratos.

3) Penalização: determinam-se os valores esperados para:

- Fator de majoração da penalização de subcontratação; e

- Fator de majoração da penalização de sobrecontratação;

4) Parâmetros de execução:

- Estipula-se a taxa de desconto para trazer os prejuízos e ganhos anuais a valor presente;

- Determinam-se quais leilões cujos volumes devem ser considerados na execução, classificando-os como:

a. sujeitos a otimização; ou

b. fixos, sendo que neste caso os valores podem estar fixos por conta da já ocorrência do leilão ou, simplesmente, fixados em zero para que o modelo não o considere no processo de otimização; 


\begin{tabular}{|l|c|l|}
\hline Mega-leilão & Otimiza/Fixo & Valor (se fixo) \\
\hline 2004 para entrega em 2005 & Otimiza & \\
\hline 2004 para entrega em 2006 & Otimiza & \\
\hline 2004 para entrega em 2007 & Otimiza & \\
\hline 2005 para entrega em 2008 & Otimiza & \\
\hline 2005 para entrega em 2009 & Otimiza & \\
\hline Leilōes de A-3 & Otimiza/Fixo & Valor (se fixo) \\
\hline 2005 para entrega em 2007 & Fixo & \\
\hline 2005 para entrega em 2008 & Otimiza & \\
\hline 2006 para entrega em 2009 & Otimiza & \\
\hline Leilões de A-5 & Otimiza/Fixo & Valor (se fixo) \\
\hline 2005 para entrega em 2009 & Otimiza & \\
\hline 2005 para entrega em 2010 & Otimiza & \\
\hline 2006 para entrega em 2011 & Otimiza & \\
\hline Reduções & Otimiza/Fixo & Valor (se fixo) \\
\hline 2006 & Otimiza & \\
\hline 2007 & Otimiza & \\
\hline 2008 & Otimiza & \\
\hline \multicolumn{2}{|c|}{} \\
\hline
\end{tabular}

Figura 5.3 - Tela de entrada para definição dos leilões a serem considerados

- Parâmetros definidos em decreto e, teoricamente, de modificação mais simples do que aqueles definidos em Lei.

\begin{tabular}{|c|r|}
\hline Parâmetros Decreto & Valor \\
\hline Limite Contratação A-1 Transição & $1 \%$ \\
\hline Limite Repasse Acima Limite A-1 Transição & $70 \%$ \\
\hline Limite Contratação A-3 para Incentivo & $2 \%$ \\
\hline Limite Contratação Ajuste & $1 \%$ \\
\hline Limite Redução CCEARs & $4 \%$ \\
\hline Máxima reposição energia existente & $5 \%$ \\
\hline Limite de Sobre-contratação & $3 \%$ \\
\hline
\end{tabular}

Figura 5.4 - Tela de entrada dos parâmetros definidos em Decreto

Com base nestes dados de entrada, o modelo calcula o prejuízo (e eventuais ganhos) correspondente a cada indivíduo da geração.

O indivíduo representa volumes de contratação em cada leilão e percentuais de redução dos contratos de energia existente. Aqueles indivíduos com menores prejuízos são classificados de tal forma a terem mais chance de se reproduzirem, perpetuando seus genes na geração seguinte; em outras palavras, a probabilidade de reprodução é feita proporcional ao Valor Presente dos prejuízos esperados ajustados $^{15}$.

\footnotetext{
${ }^{15}$ A todos os prejuízos calculados, soma-se uma parcela de ajuste igual ao módulo do maior prejuízo, de forma a levar todos os valores para números não negativos. A função "prejuízo" foi, portanto,
} 
De forma esquemática, o modelo pode ser representado conforme figura abaixo.

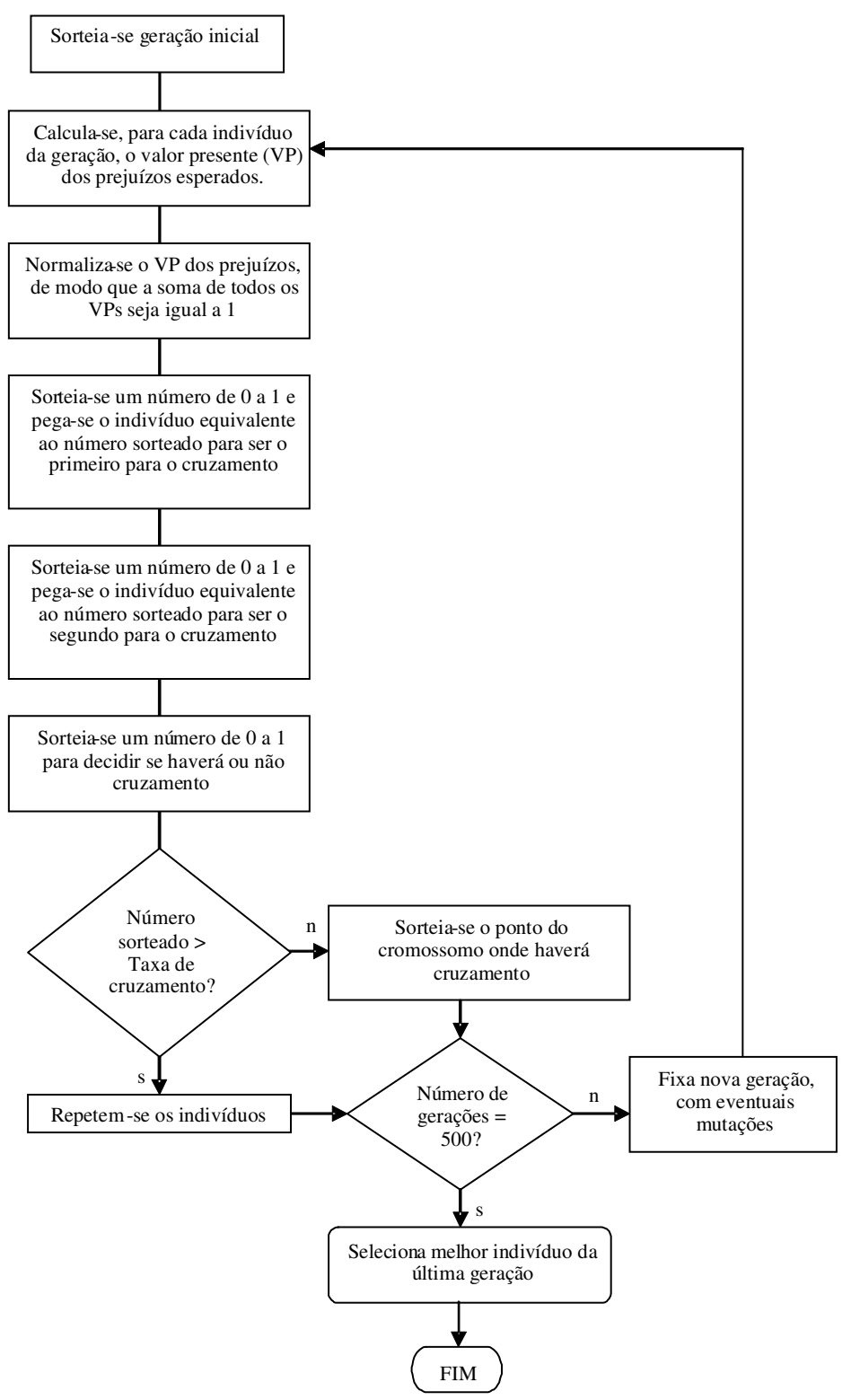

Figura 5.5 - Algoritmo genético esquematizado

O modelo traz como saídas, baseado no melhor indivíduo da última geração:

- Os volumes a serem contratados em cada leilão; e

adotada como "aptidão" dos indivíduos (alternativas de contratação) que serão trabalhados no algoritmo genético. 
- O valor de redução dos contratos de energia existente a serem aplicados anualmente.

\subsection{Parâmetros e características de desempenho}

Para a otimização da contratação, a tradução do problema em genes foi feita conforme indicado na tabela a seguir. Para definir o número de genes para cada variável é necessário que se considere a ordem de grandeza que seu valor deve alcançar e qual a margem de erro aceitável e compatível com os objetivos em mente ${ }^{16}$

Para possibilitar que o modelo proceda à otimização independentemente do tamanho da Distribuidora a ser simulada, ou seja, independente da ordem de grandeza dos números envolvidos, trabalha-se com valores percentuais em relação à demanda prevista para 2005. Assim, supondo que a carga da distribuidora no primeiro ano seja de 500 MW médios, o modelo entende o número 10 no processo de otimização como sendo 50 MW médios.

Desta forma, em sendo os valores percentuais, é razoável admitir que:

- No Mega-leilão de Energia Existente a distribuidora deva precisar contratar não mais de $50 \%{ }^{17}$ de sua carga por ano, daí o valor máximo ser $63\left(2^{6}-1\right)$, com precisão de $1 \%$ da carga total, ou seja, o gene pode conter valores de 1 a 63 , variando de 1 em 1 ;

\footnotetext{
${ }^{16}$ Como o objetivo do modelo não é guiar a contratação da Distribuidora (para este fim seria necessário um modelo mais detalhado), mas sim auxiliar os geradores a prever o comportamento daqueles agentes, é aceitável que o resultado não apresente grande precisão. Mais ainda, quanto mais preciso o modelo, mais lenta fica sua execução, de forma que deve ser feito um balanço entre precisão e eficiência.

${ }^{17}$ Como o Mega-leilão deveria repor parte significativa da energia dos Contratos Iniciais que estavam vencendo (contratos assinados na transição do modelo estatal para o modelo Re-seb, com decaimento de $25 \%$ ao ano a partir de 2003), o volume deveria ser de no mínimo 25\%; por outro lado, restringir o volume a ser contratado em $31 \%$ (em outras palavras, a 5 bits) poderia eliminar situações particulares em que se poderia haver outros contratos vencendo na mesma data.
} 
- Uma Distribuidora não tenha crescimento acima de $6 \%$ ao ano e que a contratação de energia em "A-3" seja, por conta dos incentivos do modelo, menos da metade da contratação em "A-5", daí os valores máximos serem 3,1 (equivalente a $\left(2^{5}-1\right) / 10$ ) para "A-3", e 6,3 (equivalente a $\left(2^{6}-1\right) / 10$ ) para “A-5”, com precisão para ambos de $0,1 \%$ da carga total, ou seja, para "A-3" pode-se assumir valores entre 0,0 e 3,1 e para "A-5" entre 0,0 e 6,3, ambos variando de 0,1 em 0,1 ;

Desta forma, o vetor do indivíduo, fica assim caracterizado:

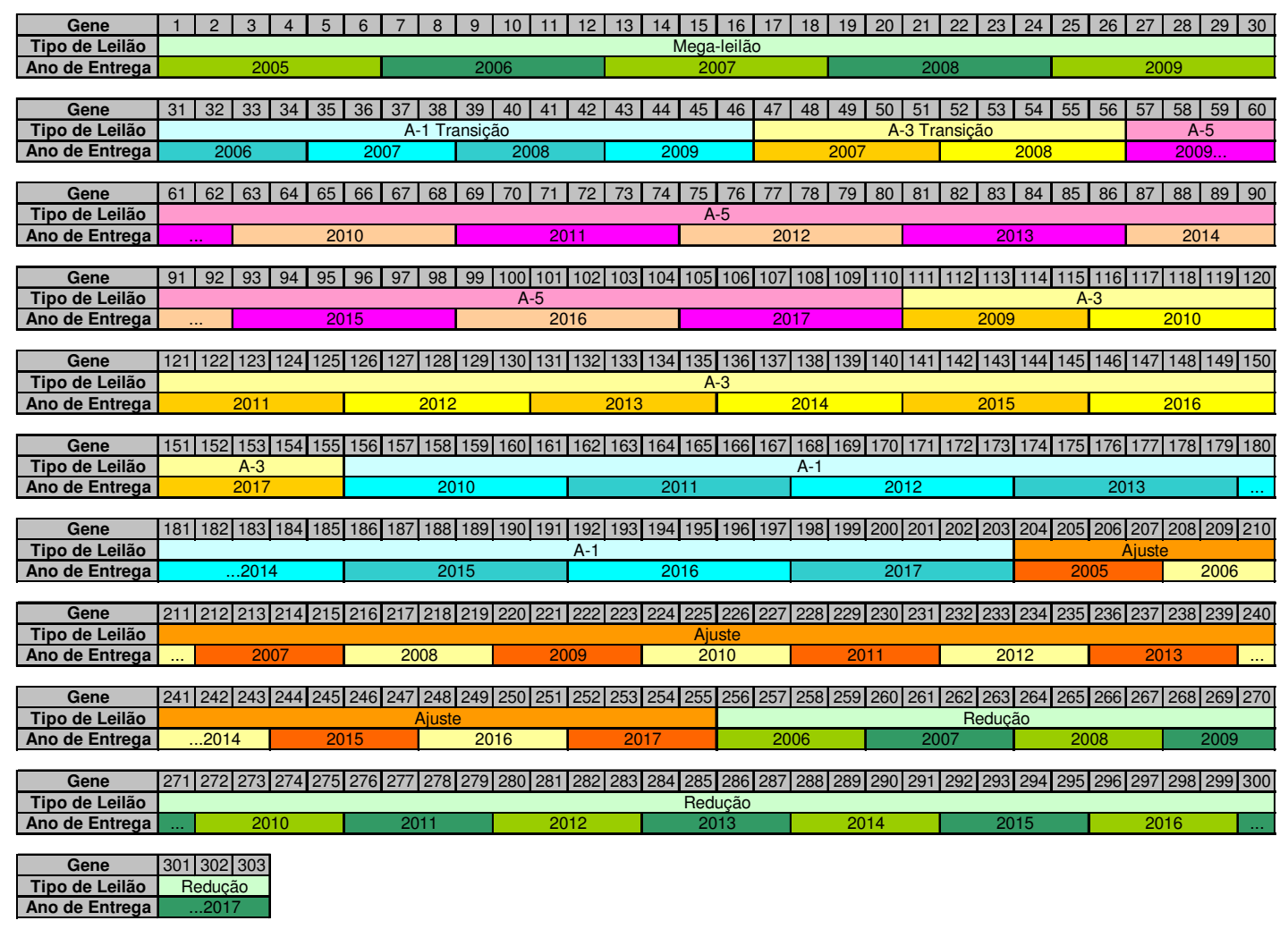

Figura 5.6 - Vetor representando o indivíduo na otimização

A tabela abaixo sintetiza o indicado na figura. 
Tabela 5.2 - Síntese das variáveis do modelo

\begin{tabular}{|c|c|c|c|c|}
\hline Variável de decisão & $\begin{array}{l}\text { Número de } \\
\text { variáveis } \\
\text { (anos) }\end{array}$ & $\begin{array}{l}\text { Genes } \\
\text { (bits) }\end{array}$ & $\begin{array}{l}\text { Valores } \\
\text { possíveis }\end{array}$ & Discretização \\
\hline $\begin{array}{c}\text { Contratação no Mega- } \\
\text { Leilão }\end{array}$ & 5 & 6 & 0 a 63 & 1 \\
\hline $\begin{array}{l}\text { Contratação nos } \\
\text { Leilões de A-1 na } \\
\text { transição }\end{array}$ & 4 & 4 & 0 a 1,5 & 0,1 \\
\hline $\begin{array}{l}\text { Contratação nos } \\
\text { Leilões de A-3 na } \\
\text { transição }\end{array}$ & 2 & 5 & 0 a 3,1 & 0,1 \\
\hline $\begin{array}{l}\text { Contratação nos } \\
\text { Leilões de A-5, em } \\
\text { regime permanente }\end{array}$ & 9 & 6 & 0 a 6,3 & 0,1 \\
\hline $\begin{array}{l}\text { Contratação nos } \\
\text { Leilões de A-3, em } \\
\text { regime permanente }\end{array}$ & 9 & 5 & 0 a 3,1 & 0,1 \\
\hline $\begin{array}{l}\text { Contratação nos } \\
\text { Leilões de A-1, em } \\
\text { regime permanente }\end{array}$ & 8 & 6 & 0 a 63 & 1 \\
\hline $\begin{array}{l}\text { Contratação nos } \\
\text { Leilões de Ajuste }\end{array}$ & 13 & 4 & 0 a $1,5^{*}$ & 0,1 \\
\hline $\begin{array}{l}\text { Percentual de redução } \\
\text { dos contratos de } \\
\text { energia existente }\end{array}$ & 12 & 4 & 0 a 4,00 & 0,27 \\
\hline TOTAL & 62 & 303 & & \\
\hline
\end{tabular}

* O valor máximo é limitado a $1 \%$ da carga da distribuidora naquele ano.

A obtenção dos parâmetros não é tarefa trivial, pois não há uma regra que os relacione ao tipo do problema ou ao tamanho do cromossomo. Deve-se obtê-los de 
forma empírica, ou seja, na base da tentativa e erro; desta forma, partiram-se dos resultados obtidos por Schaffer apud Barcellos (2000), reproduzidos na tabela abaixo:

Tabela 5.3 - Possíveis parâmetros para o Algoritmo Genético

\begin{tabular}{|c|c|c|}
\hline $\begin{array}{c}\text { Tamanho da } \\
\text { população }\end{array}$ & $\begin{array}{c}\text { Probabilidade de } \\
\text { recombinação }\end{array}$ & $\begin{array}{c}\text { Probabilidade de } \\
\text { mutação }\end{array}$ \\
\hline $20-30$ & $0,75-0,95$ & $0,005-0,01$ \\
\hline
\end{tabular}

Foram montados três diferentes perfis de contratação, isto é, diferentes carteiras de contratos existentes, sendo dois hipotéticos e um baseado no perfil publicado pela COPEL (2004), e foi executado o algoritmo de otimização com todas as combinações possíveis, discretizando os parâmetros da seguinte maneira:

- População: 20 e 30;

- Probabilidade de recombinação: 0,$75 ; 0,80 ; 0,85 ; 0,90$ e 0,95

- Probabilidade de mutação: 0,005 e 0,01

Assim, foram simulados 3 [perfis de contratação] $x \quad 2$ [população] $x$ [recombinação] x 2 [mutação] $=60$ casos diferentes, de onde se obteve a configuração final dos parâmetros, quais sejam:

- População: 30

- Probabilidade de recombinação: 0,95

- Probabilidade de mutação: 0,01

Os resultados são exatamente iguais àqueles apresentados por Grefenstette apud Barcellos (2000).

A simulação gera 500 gerações para alcançar a solução mais próxima possível da ótima. Nesta configuração o modelo demora aproximadamente 5 minutos para ser executado em um microcomputador Pentium IV 2,66 GHz com 512 MB de memória RAM. 


\subsection{Estudos de caso}

Uma boa forma de se avaliar o modelo é compará-lo com as aquisições efetivamente realizadas nos leilões de energia existente realizados em dezembro de 2004 e em abril de 2005 .

\subsubsection{Distribuidora típica - aferição do modelo}

Em 17/12/2004 a COPEL publicou um boletim [COPEL, 2004] onde apresentava seu perfil de contratação pós-leilão, contendo os volumes de todos os contratos de compra de energia desta Distribuidora tanto no leilão como aqueles assinados antes da publicação da Lei 10.848/2004, ilustrado na figura abaixo.

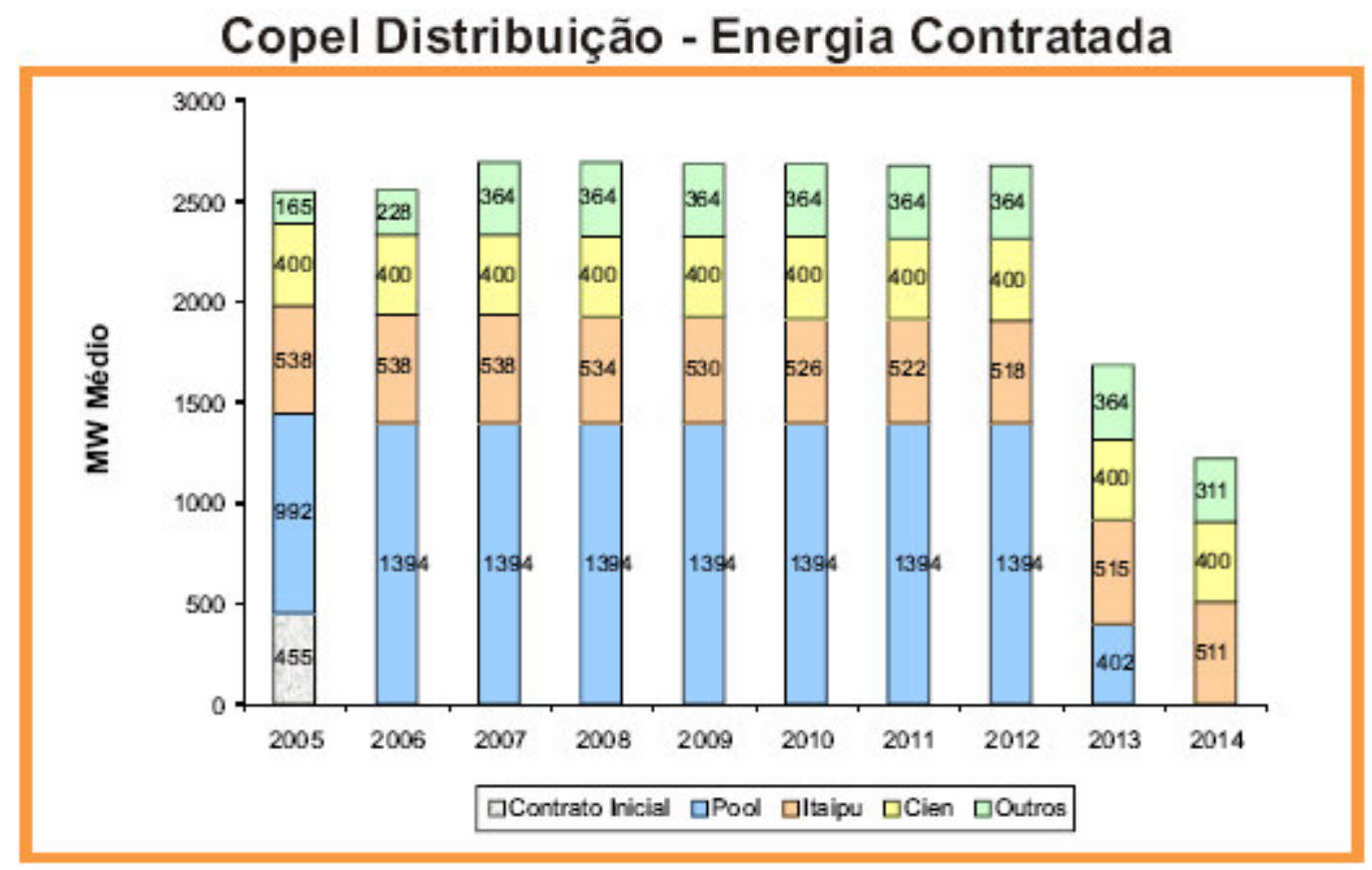

Figura 5.7 - Perfil de contratação da COPEL

Conhecendo-se tais informações, especialmente o volume dos contratos já existentes, um dos principais dados de entrada do modelo, pode-se simular o comportamento da COPEL, de forma a aferir o otimizador. 
É evidente que não se divulgaram as premissas adotadas por esta companhia para a declaração de necessidade de contratação, de maneira que os parâmetros de simulação devem ser estimados. Inicialmente, deve-se fornecer ao modelo os preços esperados, em R $\$$ /MWh, para os diversos leilões, nos diversos anos, bem como os parâmetros de penalização (PLD para sub e sobrecontratação) e a Taxa de Desconto considerada para cálculo do Valor Presente.

\begin{tabular}{|c|c|c|c|c|c|c|c|c|c|c|c|c|}
\hline & 2005 & 2006 & 2007 & 2008 & 2009 & 2010 & 2011 & 2012 & 2013 & 2014 & 2015 & \\
\hline $\mathrm{A}-5$ & & & & & 95,00 & 95,00 & 95,00 & 95,00 & 95,00 & 95,00 & 95,00 & $80 \%$ \\
\hline $\mathrm{A}-3$ & & & 95,00 & 95,00 & 100,00 & 100,00 & 100,00 & 100,00 & 100,00 & 100,00 & 100,00 & $20 \%$ \\
\hline VR & 65,00 & 70,00 & 95,00 & 95,00 & 96,00 & 96,00 & 96,00 & 96,00 & 96,00 & 96,00 & 96,00 & \\
\hline A-1 & 55,00 & 65,00 & 75,00 & 85,00 & 90,00 & 90,00 & 90,00 & 90,00 & 90,00 & 90,00 & 90,00 & \\
\hline Ajuste & 25,00 & 45,00 & 65,00 & 85,00 & 90,00 & 90,00 & 90,00 & 90,00 & 90,00 & 90,00 & 90,00 & \\
\hline Mega-leilão & 65,00 & 70,00 & 75,00 & 85,00 & 95,00 & & & & & & & Fator \\
\hline PLD Sub & 100,00 & 100,00 & 100,00 & 100,00 & 200,00 & 200,00 & 200,00 & 200,00 & 200,00 & 200,00 & 200,00 & 1 \\
\hline PLD Sobre & 20,00 & 20,00 & 20,00 & 20,00 & 20,00 & 20,00 & 20,00 & 20,00 & 20,00 & 20,00 & 20,00 & 1 \\
\hline
\end{tabular}

Figura 5.8 - Entrada de parâmetros numéricos no modelo para o caso COPEL

Também se deve fornecer os parâmetros de execução, conforme descrito no item 5.1:

\begin{tabular}{|c|c|c|}
\hline Mega-leilão & Otimiza/Fixo & Valor (se fixo) \\
\hline 2004 para entrega em 2005 & Otimiza & \\
\hline 2004 para entrega em 2006 & Otimiza & \\
\hline 2004 para entrega em 2007 & Otimiza & \\
\hline 2005 para entrega em 2008 & Otimiza & \\
\hline 2005 para entrega em 2009 & Otimiza & \\
\hline Leilões de A-3 & Otimiza/Fixo & Valor (se fixo) \\
\hline 2005 para entrega em 2007 & Fixo & - \\
\hline 2005 para entrega em 2008 & Otimiza & \\
\hline 2006 para entrega em 2009 & Otimiza & \\
\hline Leilões de A-5 & Otimiza/Fixo & Valor (se fixo) \\
\hline 2005 para entrega em 2009 & Otimiza & \\
\hline 2005 para entrega em 2010 & Otimiza & \\
\hline 2006 para entrega em 2011 & Otimiza & \\
\hline Reduções & Otimiza/Fixo & Valor (se fixo) \\
\hline 2006 & Otimiza & \\
\hline 2007 & Otimiza & \\
\hline 2008 & Otimiza & \\
\hline
\end{tabular}

\begin{tabular}{|c|r|}
\hline Parâmetros Decreto & Valor \\
\hline Limite Contratação A-1 Transição & $1 \%$ \\
\hline Limite Repasse Acima Limite A-1 Transição & $70 \%$ \\
\hline Limite Contratação A-3 para Incentivo & $2 \%$ \\
\hline Limite Contratação Ajuste & $1 \%$ \\
\hline Limite Redução CCEARs & $4 \%$ \\
\hline Máxima reposição energia existente & $5 \%$ \\
\hline Limite de Sobre-contratação & $3 \%$ \\
\hline
\end{tabular}

Figura 5.9 - Entrada de parâmetros de execução para o caso COPEL

Finalmente, um dos principais parâmetros a ser estimado, do ponto de vista particular deste estudo de caso, é o crescimento previsto da carga. Estimou-se um crescimento de carga de 3\% no ano de 2006 (considerando um aquecimento maior da economia) e, em seguida, um valor constante de $2,5 \%$ ao ano. Note-se que o valor do campo “Contratos Existentes" foi obtido da figura 5.1. 


\begin{tabular}{|c|c|c|c|c|c|c|c|c|c|c|c|}
\hline & 2005 & 2006 & 2007 & 2008 & 2009 & 2010 & 2011 & 2012 & 2013 & 2014 & 2015 \\
\hline \multicolumn{2}{|c|}{ Crescimento estimado } & $3,0 \%$ & $2,5 \%$ & $2,5 \%$ & $2,5 \%$ & $2,5 \%$ & $2,5 \%$ & $2,5 \%$ & $2,5 \%$ & $2,5 \%$ & $2,5 \%$ \\
\hline Demanda & 2.550 & 2.627 & 2.692 & 2.759 & 2.828 & 2.899 & 2.972 & 3.046 & 3.122 & 3.200 & 3.280 \\
\hline Contratos Existentes & 1.558 & 1.166 & 1.302 & 1.298 & 1.294 & 1.290 & 1.286 & 1.282 & 1.279 & 1.255 & 1.255 \\
\hline
\end{tabular}

Figura 5.10 - Entrada de parâmetros do mercado no modelo para o caso COPEL

De acordo com o modelo desenvolvido, a declaração de necessidade que deveria ser entregue pela COPEL seria a seguinte:

Contratação nos leilões de transição de energia existente

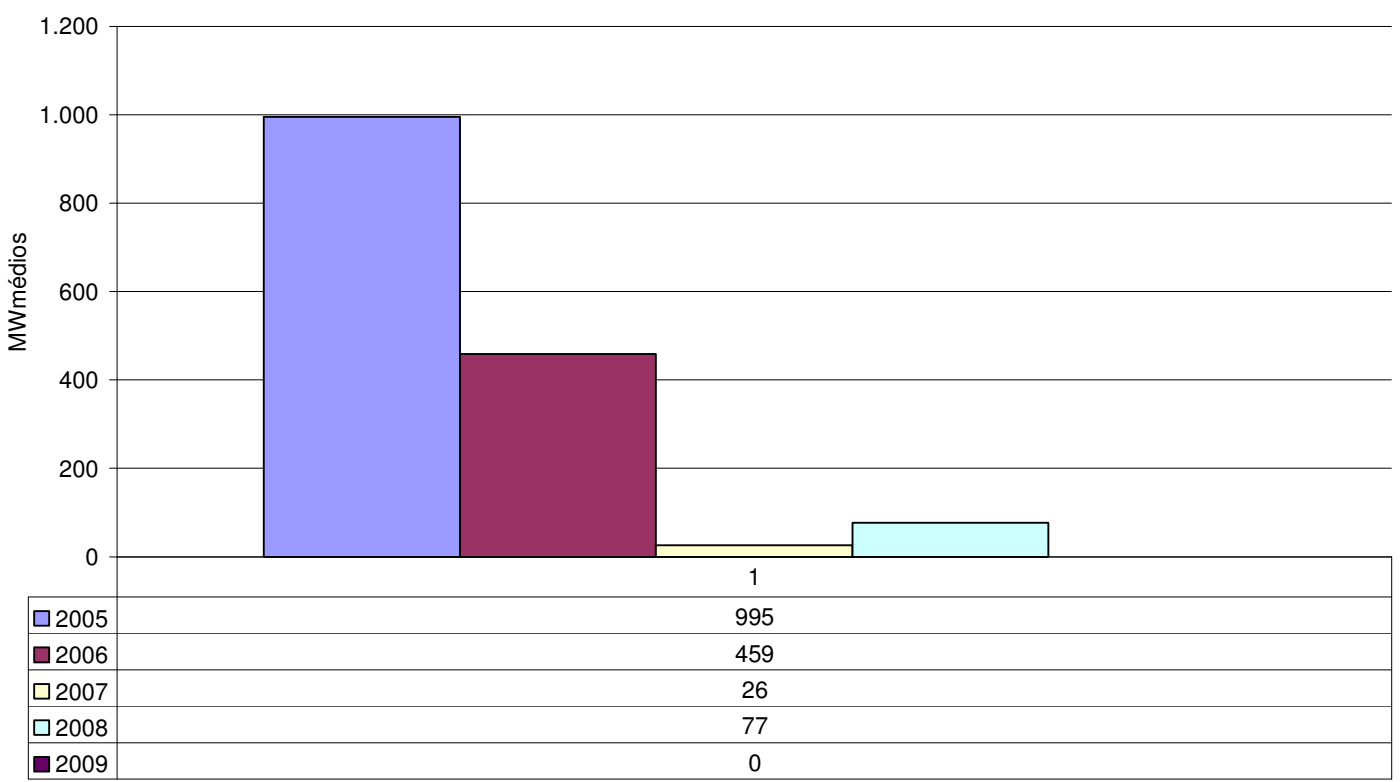

Figura 5.11 - Contratação no mega-leilão proposta para o caso COPEL

O perfil de contratação completo proposto pelo modelo é o mostrado a seguir. Apesar de o modelo ter como horizonte de estudo o ano de 2015 (mais adiante, o modelo viria a ter seu horizonte ampliado para 2017 e, em seguida, reduzido para 2011), as incertezas que envolvem o estudo fazem com que os resultados significativos sejam os de até 5 anos à frente (2010). O bloco "Existing" engloba a energia contratada no Mega-leilão, aquela contratada em "A-1", bem como as contratações de Ajuste, deduzidas das reduções permitidas pela regulamentação. 
Perfil de contratação proposto

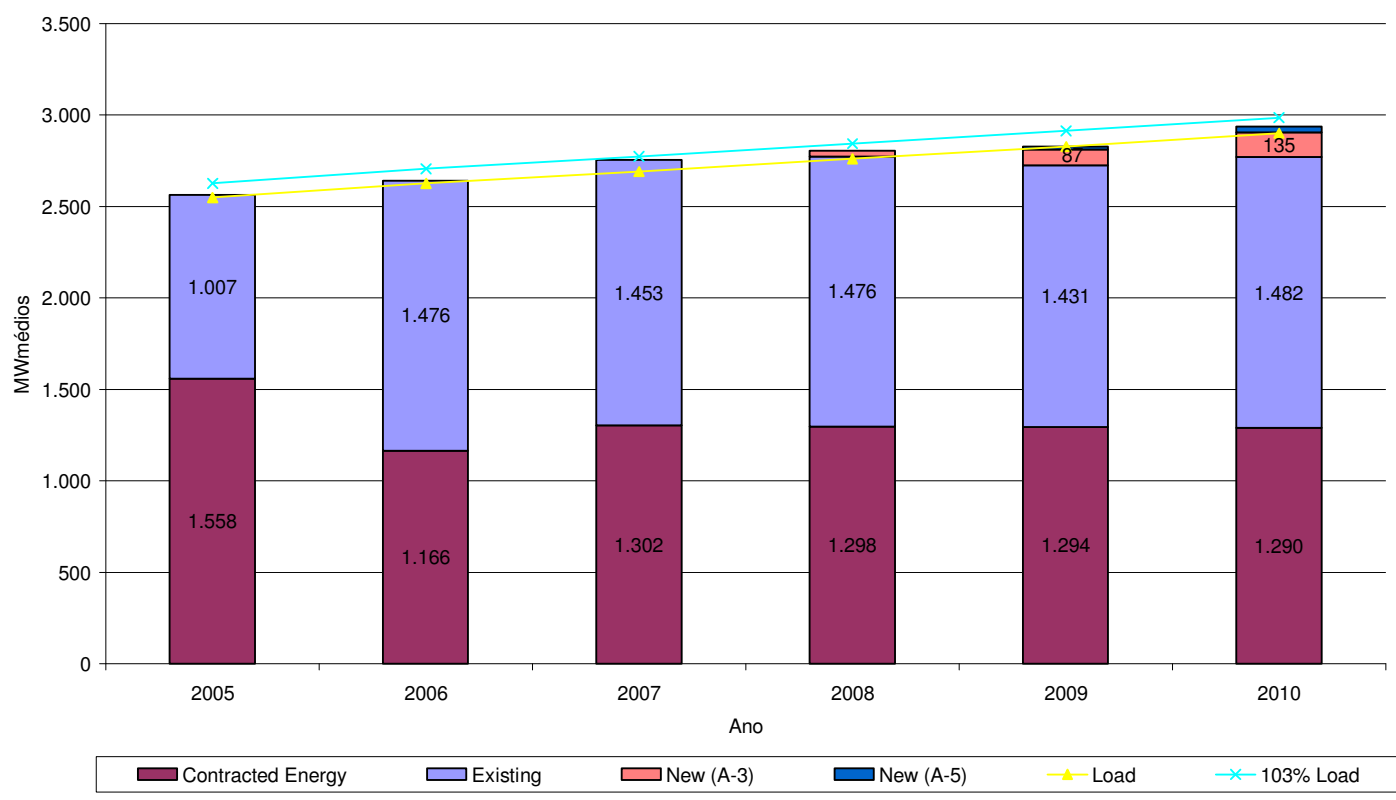

Figura 5.12 - Perfil de contratação proposto pelo modelo para o caso COPEL

Como a regra do leilão previa a possibilidade de contratação efetiva abaixo do volume declarado pelas Distribuidoras, não se pode comparar o resultado do modelo com o montante contratado, mas sim se deve compará-lo com o montante originalmente declarado.

Assim, considerando-se que a COPEL adquiriu no referido leilão os volumes indicados na primeira coluna da tabela abaixo e levando-se em consideração que o percentual de atendimento neste mesmo leilão, conforme apresentação realizada pela CCEE, foi o indicado na segunda coluna, pode-se chegar ao valor originalmente declarado pela Distribuidora. 
Tabela 5.4 - Volumes do mega-leilão relativos à COPEL

\begin{tabular}{|c|c|c|c|}
\hline \multirow{2}{*}{ Ano } & $\begin{array}{c}\text { Volume Contratado } \\
\text { (MWmédio) }\end{array}$ & $\begin{array}{c}\text { Percentual atendido no } \\
\text { leilão } \\
\text { (A) }\end{array}$ & $\begin{array}{c}\text { Volume declarado } \\
\text { (MWmédio) } \\
(\mathrm{C})=(\mathrm{A}) /(\mathrm{B})\end{array}$ \\
\hline 2005 & 992 & $98,92 \%$ & 1003 \\
\hline 2006 & 402 & $91,74 \%$ & 438 \\
\hline 2007 & 0 & $100,0 \%$ & 0 \\
\hline
\end{tabular}

Finalmente, considerando que a discretização das variáveis para possibilitar a codificação em genes possui uma margem de erro de $1 \%$ da carga, pode-se concluir pelo sucesso na modelagem proposta.

Tabela 5.5 - Comparação dos resultados do modelo com dados da COPEL

\begin{tabular}{|c|c|c|c|}
\hline Ano & $\begin{array}{c}\text { Volume declarado } \\
\text { (MWmédio) }\end{array}$ & $\begin{array}{c}\text { Resultado do Modelo } \\
\text { (MWmédio) }\end{array}$ & $\begin{array}{c}\text { Diferença declarado vs. } \\
\text { modelo (\% da carga) }\end{array}$ \\
\hline 2005 & 1003 & 995 & $8(0,3 \%)$ \\
\hline 2006 & 438 & 459 & $21(0,8 \%)$ \\
\hline 2007 & 0 & 26 & $26(1,0 \%)$ \\
\hline
\end{tabular}

A evolução dos indivíduos pode ser verificada na figura abaixo, onde se observa o valor da função de avaliação (valor presente dos prejuízos esperados) ao longo das gerações. 


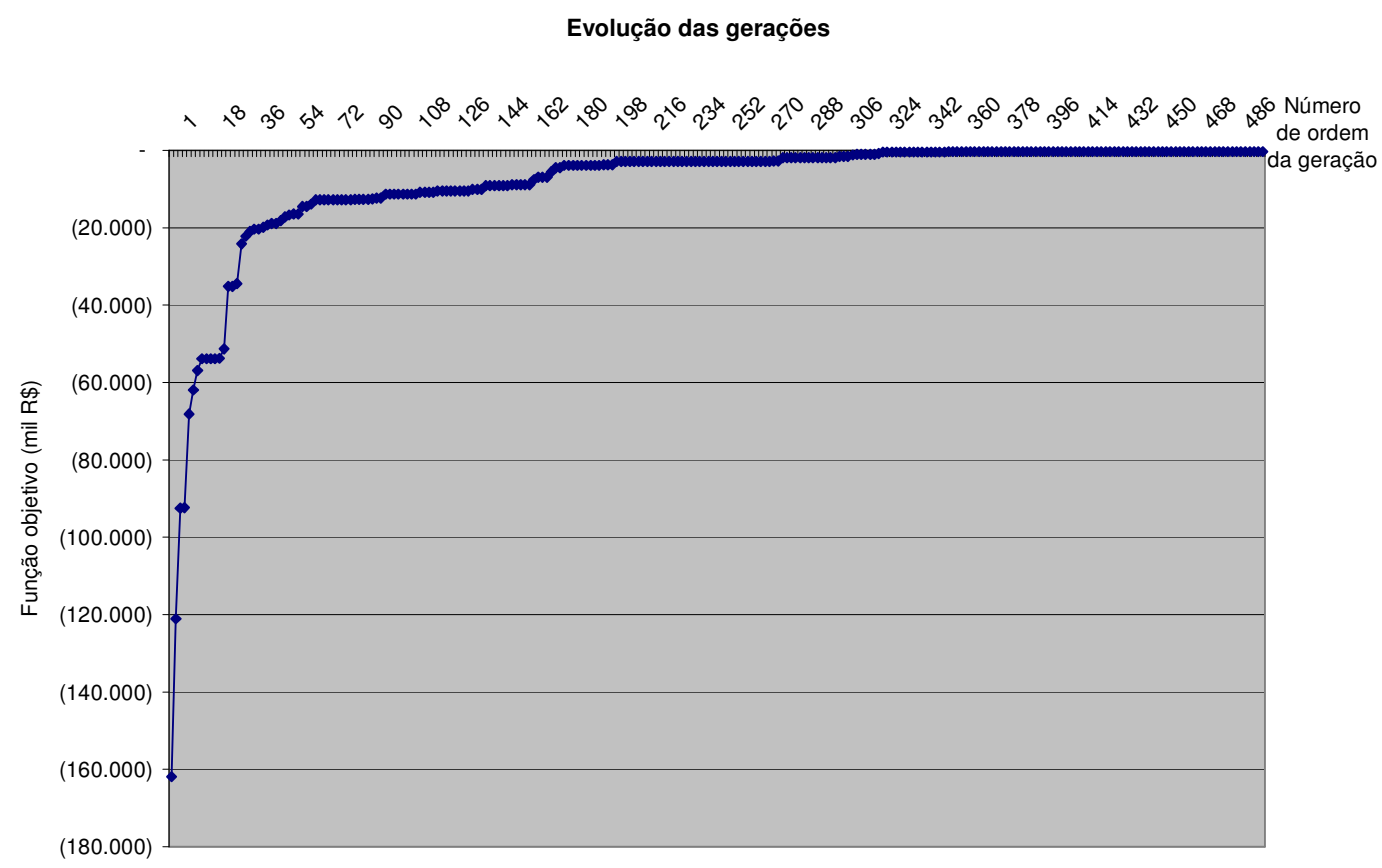

Figura 5.13 - Evolução das gerações para o caso COPEL

Evolução das gerações - zoom nas últimas 250 gerações

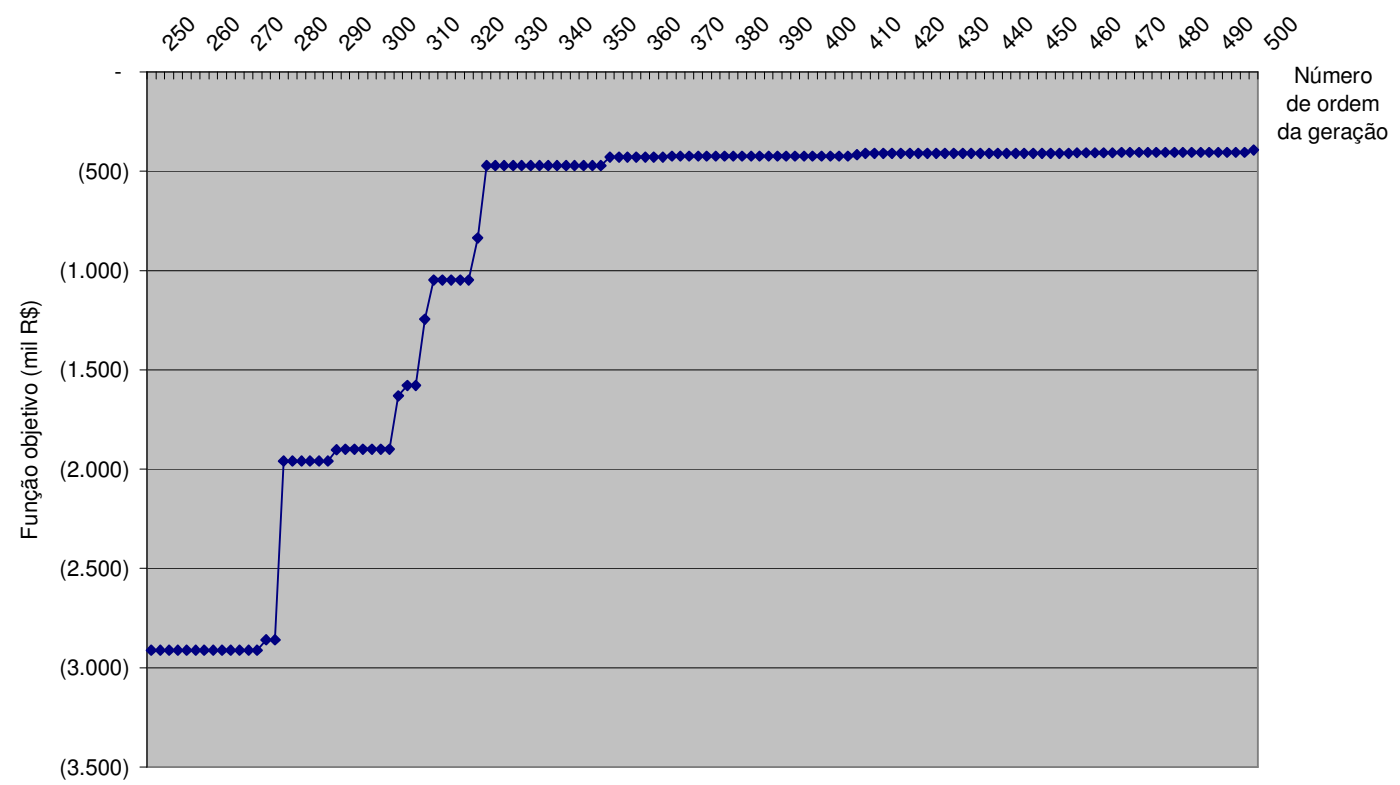

Figura 5.14 - Zoom na evolução das últimas 250 gerações para o caso COPEL

Entre a realização da primeira e segunda etapa do Mega-leilão, houve uma pequena alteração no prazo dos contratos. Inicialmente, previa-se que a energia para entrega 
em 2008 e 2009 seria contratada por 5 anos, entretanto o Ministério de Minas e Energia alterou este prazo para 8 anos.

Como a simulação acima foi feita considerando aquele primeiro prazo dos contratos, foi necessária uma adaptação ao modelo, inclusive alterando o horizonte do estudo (agora, 2017). Uma nova simulação foi realizada com os mesmos parâmetros, resultando na seguinte declaração de necessidade:

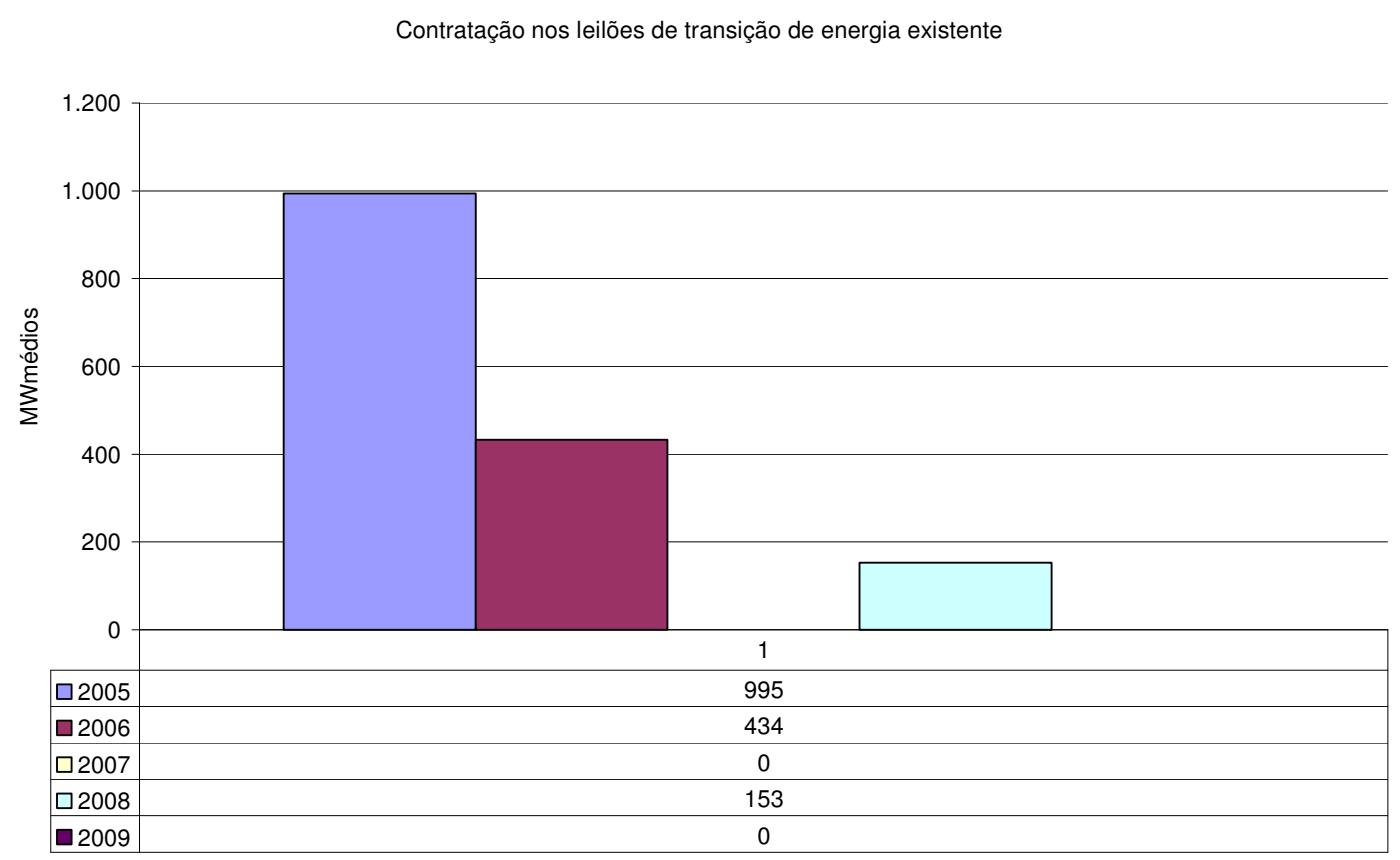

Figura 5.15 - Contratação no mega-leilão proposta pelo modelo após alteração da duração dos contratos de 2008 e 2009

Se, novamente, for considerada a margem de erro de 1\% da carga (26 MWmédios), nota-se que a necessidade de contratação do leilão da energia para entrega entre 2005 e 2007 não seria significantemente influenciada por tal alteração de prazos.

O gráfico abaixo ilustra a comparação entre os resultados do modelo e os valores declarados pela COPEL considerando também o segundo leilão de energia existente, de forma a validar a calibração do modelo. 
Contratação nos leilões de transição de energia existente - após alteração dos contratos 2008 e 2009

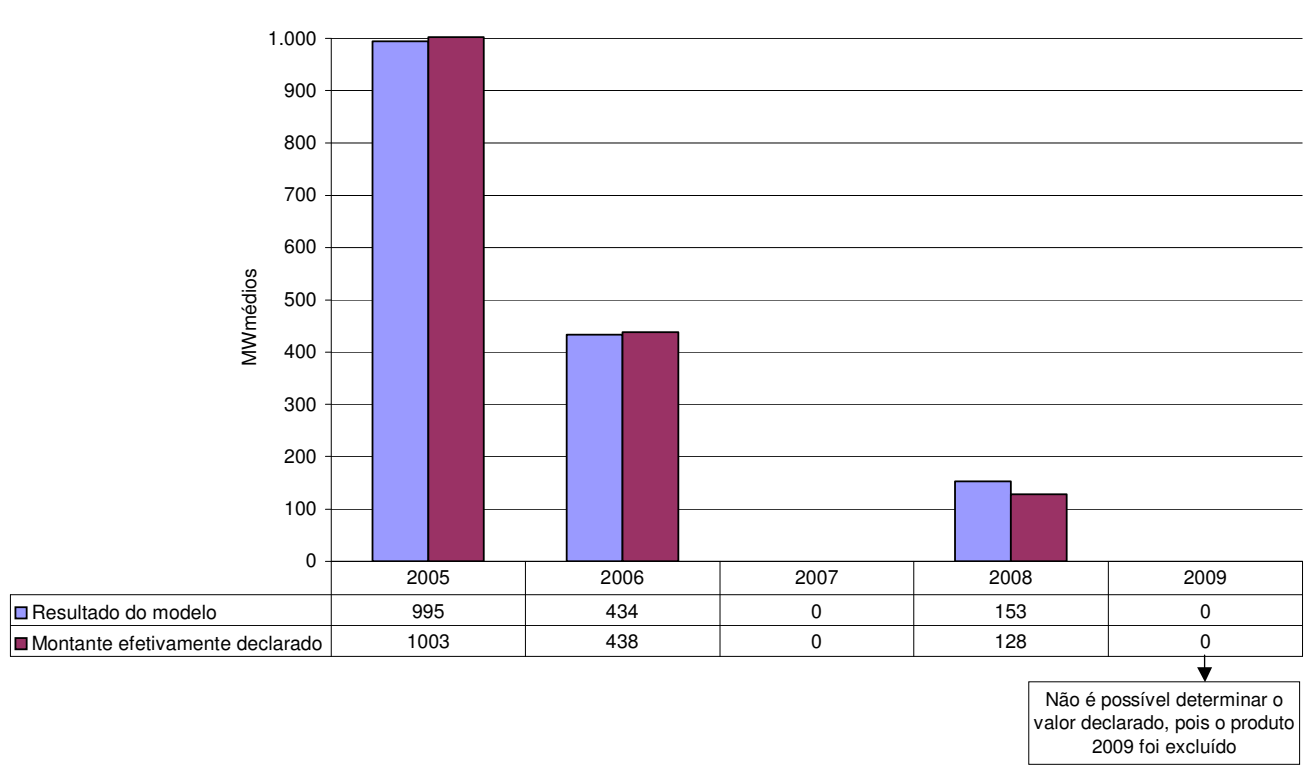

Figura 5.16 - Resultado da calibração do modelo

Na seqüência dos estudos, na tentativa de se simplificar o modelo e considerando as variáveis de entrada e saída mais relevantes para o processo de decisão, decidiu-se:

1. Pela redução do período de estudo (de 2017 para 2011): esta alteração possibilita maior segurança para o usuário do modelo definir as variáveis de entrada, pois implicam em menores incertezas, além de garantir maior confiabilidade aos dados de saída; e

2. Eliminação da variável de decisão "leilão de ajuste": esta modalidade de leilão foi criada para que a distribuidora corrija eventuais desvios de contratação no curto prazo com volumes reduzidos por um período também reduzido, de modo que sua inclusão em um modelo de longo prazo parece ser pouco representativo.

Estas alterações possibilitaram a redução do string para menos da metade de seu tamanho original (vide Figura 5.6), passando para o ilustrado abaixo, além de reduzir significantemente o tempo de processamento. 


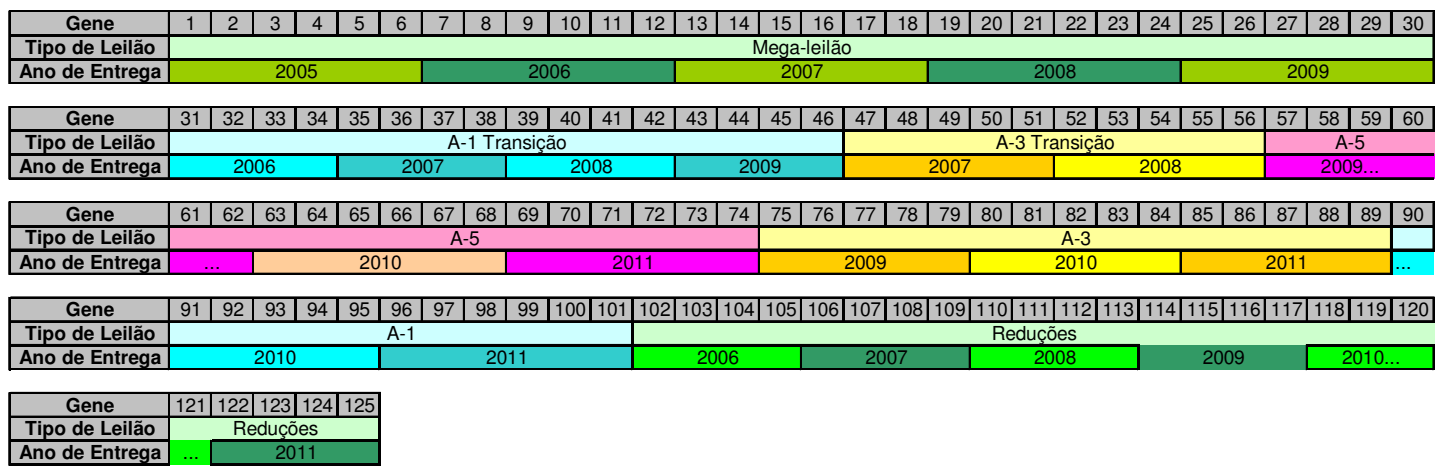

Figura 5.17 - Vetor representando o indivíduo na otimização, com redução do horizonte de estudo

Para validar esta escolha, o modelo foi rodado mais uma vez, com os mesmos dados de entrada, obtendo-se o resultado abaixo:

Contratação nos leilões de transição de energia existente - após alteração dos contratos 2008 e 2009

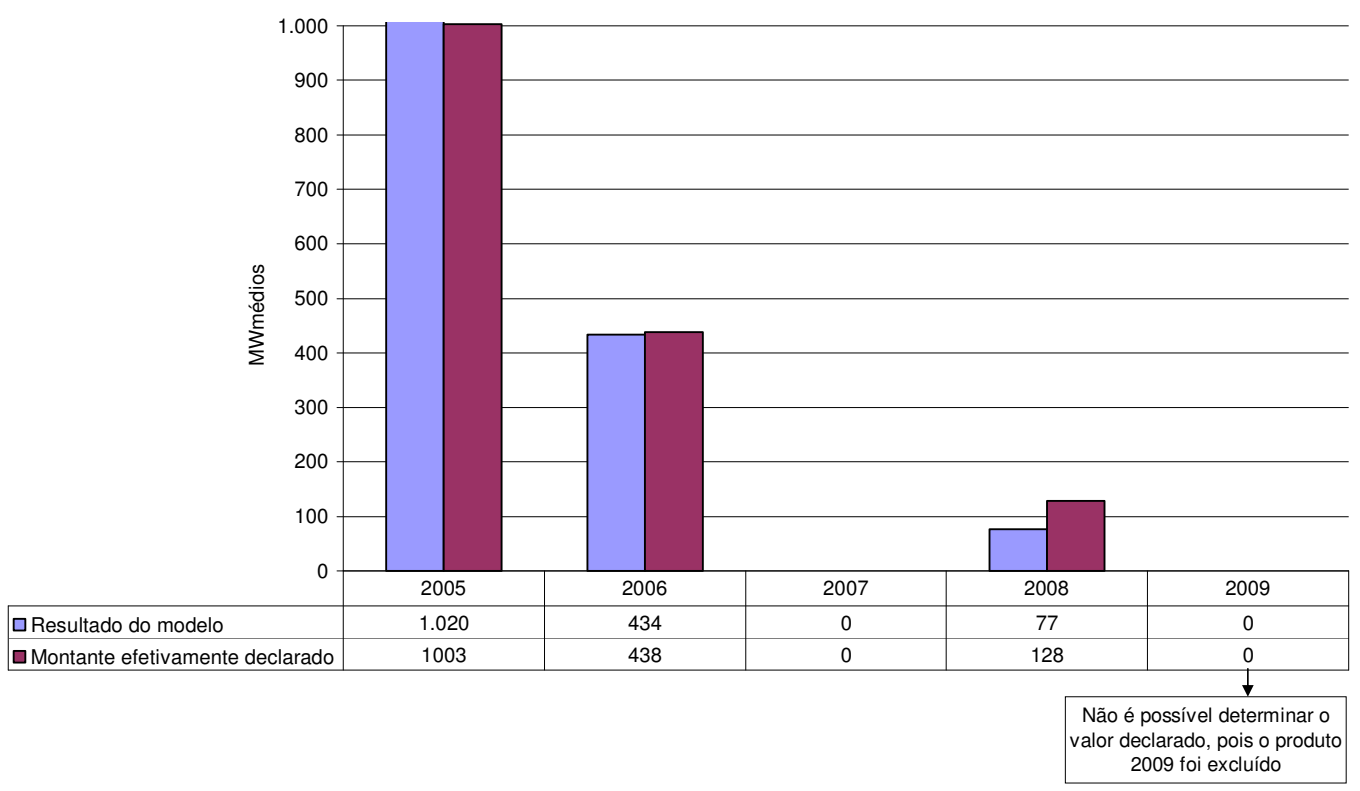

Figura 5.18 - Resultado do modelo com horizonte reduzido

Nota-se grande aderência dos resultados agora obtidos com os anteriores, exceto pelo resultado de 2008. Maiores investigações demonstraram a sensibilidade dos resultados com os dados de entrada do mercado, de maneira que com uma pequena alteração no crescimento esperado do mercado de 2007 e 2008 - foram alterados de $2,5 \%$ para $2,7 \%$ - obteve-se o que se segue. 
Contratação nos leilões de transição de energia existente - após alteração dos contratos 2008 e 2009

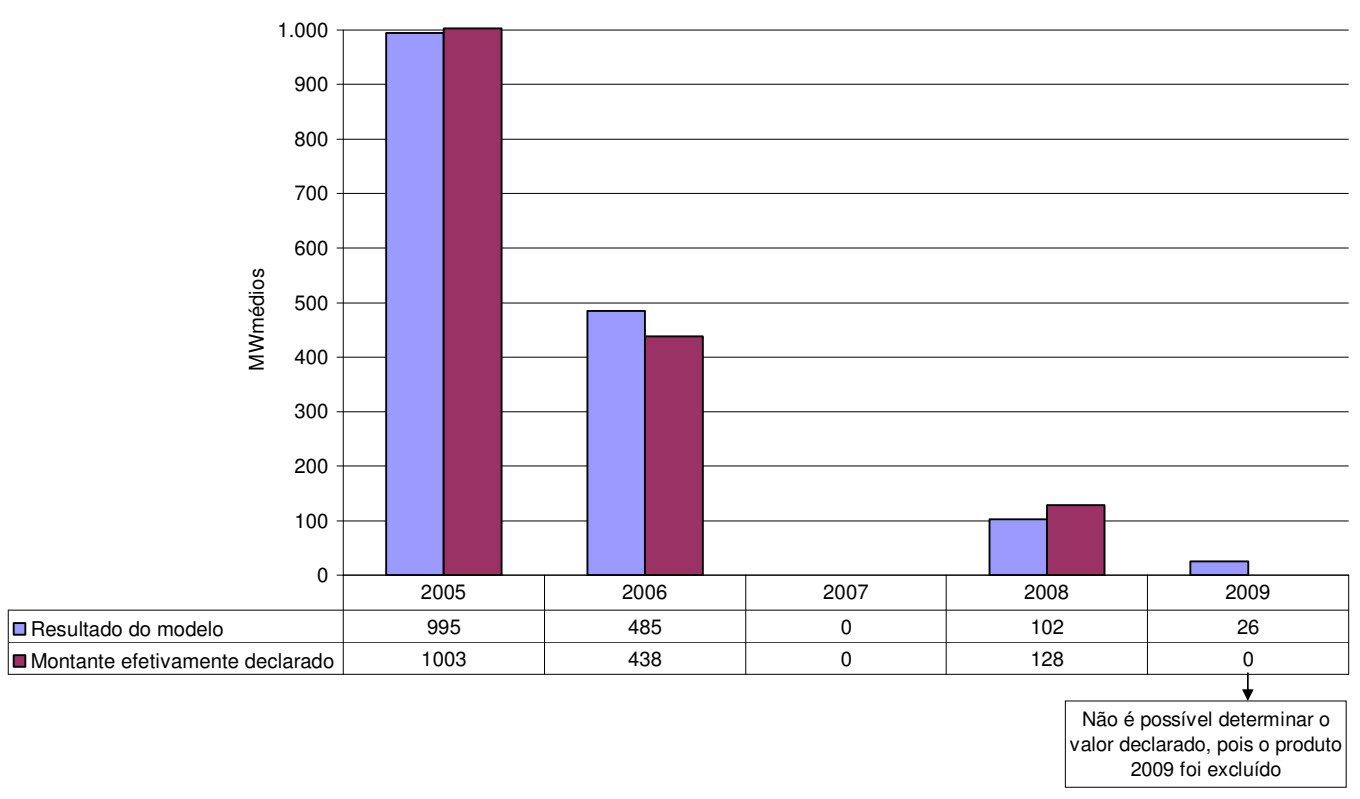

Figura 5.19 -Resultado do modelo com horizonte reduzido e pequenas alterações nos dados de entrada

\subsubsection{Caso Brasil}

Com o modelo aparentemente validado, inclusive com suas simplificações, conforme apontado no item anterior, pode-se passar a uma análise do comportamento esperado do conjunto das Distribuidoras através da simulação de um caso com a carga agregada do Brasil.

Para tanto, o primeiro passo é a tentativa de obtenção das premissas de um caso base para o agregado das Distribuidoras do Sistema Interligado Nacional (SIN). Especialmente, trata-se de se determinar as variáveis de crescimento de mercado anual e contratos existentes no horizonte de estudo (2005-2011).

O primeiro conjunto de variáveis - crescimento de mercado anual - foi obtido dos dados apresentados no Relatório do Planejamento Energético Anual do ONS [ONS, 
2005], o qual utiliza as previsões de mercado elaboradas pelo Comitê Técnico de Estudos de Mercado (CTEM/MME).

Vale ressaltar que os dados do referido relatório do ONS consideram o mercado como um todo, englobando não apenas as Distribuidoras, mas também os Consumidores Livres e os Auto-produtores. Assim, para se estimar o segundo conjunto de variáveis - contratos existentes - devem-se considerar as seguintes três parcelas:

1. Volume de energia correspondente aos Consumidores Livres e Autoprodutores;

2. Aquisição compulsória da energia proveniente de Itaipu; e

3. Os contratos propriamente ditos, incluindo-se aí geração própria e contratos entre empresas do mesmo grupo (self-dealing) assinados antes da publicação da lei 10.848/04.

Embora possa parecer simples determinar as duas primeiras parcelas, estas formam apenas um "colchão" firme, sendo a terceira parcela uma variável de folga, de complexa obtenção. Assim sendo, não resta outra opção senão simular diversos casos com diferentes valores para este conjunto de variáveis, comparando-se os resultados dessas simulações com a declaração apresentada pelas Distribuidoras, obtendo-se então, através de tentativa e erro, um caso base de estudo.

Os valores assim obtidos estão ilustrados na figura a seguir.

\begin{tabular}{|l|r|r|r|r|r|r|r|}
\cline { 2 - 8 } \multicolumn{1}{c|}{} & \multicolumn{1}{c|}{$\mathbf{2 0 0 5}$} & \multicolumn{1}{c|}{$\mathbf{2 0 0 6}$} & \multicolumn{1}{c|}{$\mathbf{2 0 0 7}$} & \multicolumn{1}{c|}{$\mathbf{2 0 0 8}$} & $\mathbf{2 0 0 9}$ & $\mathbf{2 0 1 0}$ & $\mathbf{2 0 1 1}$ \\
\hline \multicolumn{2}{|c|}{ Crescimento estimado } & $4,8 \%$ & $4,6 \%$ & $5,1 \%$ & $5,9 \%$ & $5,9 \%$ & $5,9 \%$ \\
\hline Demanda & $\mathbf{4 6 . 4 4 6}$ & $\mathbf{4 8 . 6 6 6}$ & $\mathbf{5 0 . 9 0 0}$ & $\mathbf{5 3 . 4 7 1}$ & $\mathbf{5 6 . 6 4 4}$ & $\mathbf{6 0 . 0 0 5}$ & $\mathbf{6 3 . 5 6 6}$ \\
\hline Contratos Existentes & $\mathbf{3 8 . 0 0 0}$ & $\mathbf{3 2 . 5 0 0}$ & $\mathbf{3 3 . 8 0 0}$ & $\mathbf{3 4 . 2 0 0}$ & $\mathbf{3 1 . 0 0 0}$ & $\mathbf{3 1 . 0 0 0}$ & $\mathbf{3 1 . 0 0 0}$ \\
\hline
\end{tabular}

Figura 5.20 - Dados do caso Brasil

Desta forma, a comparação entre o resultado do modelo com os dados acima e os valores declarados nos dois primeiros leilões de energia existente é o que permite avaliar a adequação dos mesmos. 
Contratação no $1^{\circ}$ e $2^{\circ}$ leilões de energia existente (transição) - Caso Brasil

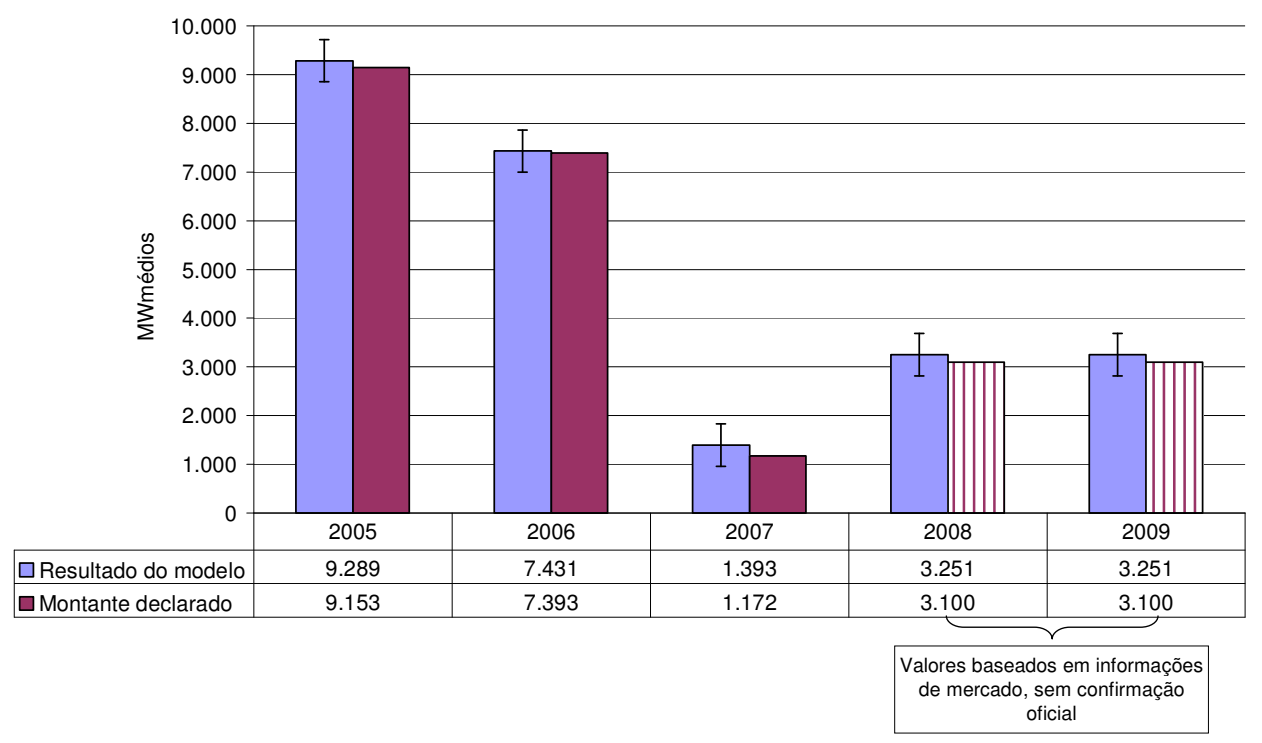

Figura 5.21 - Comparação entre simulado e real para o caso Brasil

O perfil de contratação completo obtido nesta simulação é o apresentado na Figura 5.22 .

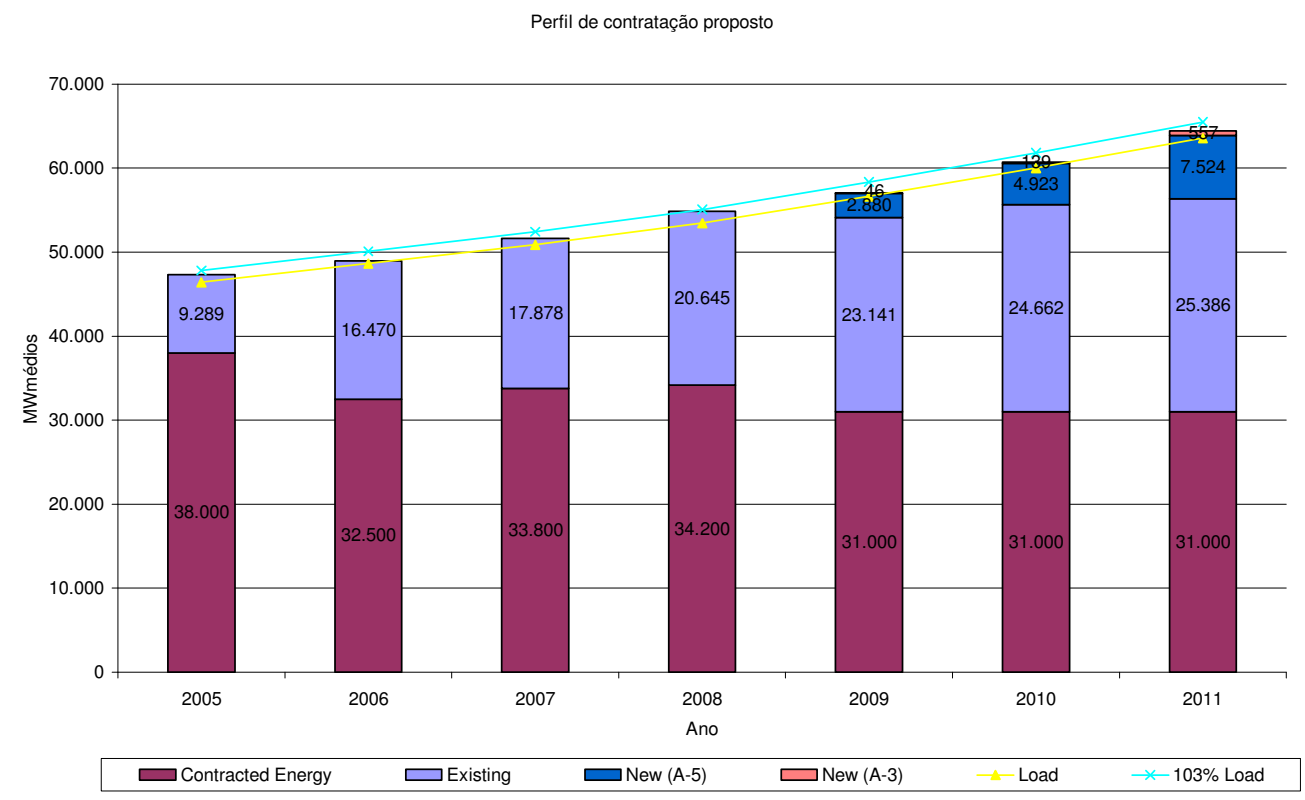

Figura 5.22 - Perfil de contratação completo do caso Brasil 
As figuras a seguir ilustram a evolução das espécies ao longo das 500 gerações. Note-se que ainda há saltos significativos nas últimas gerações.

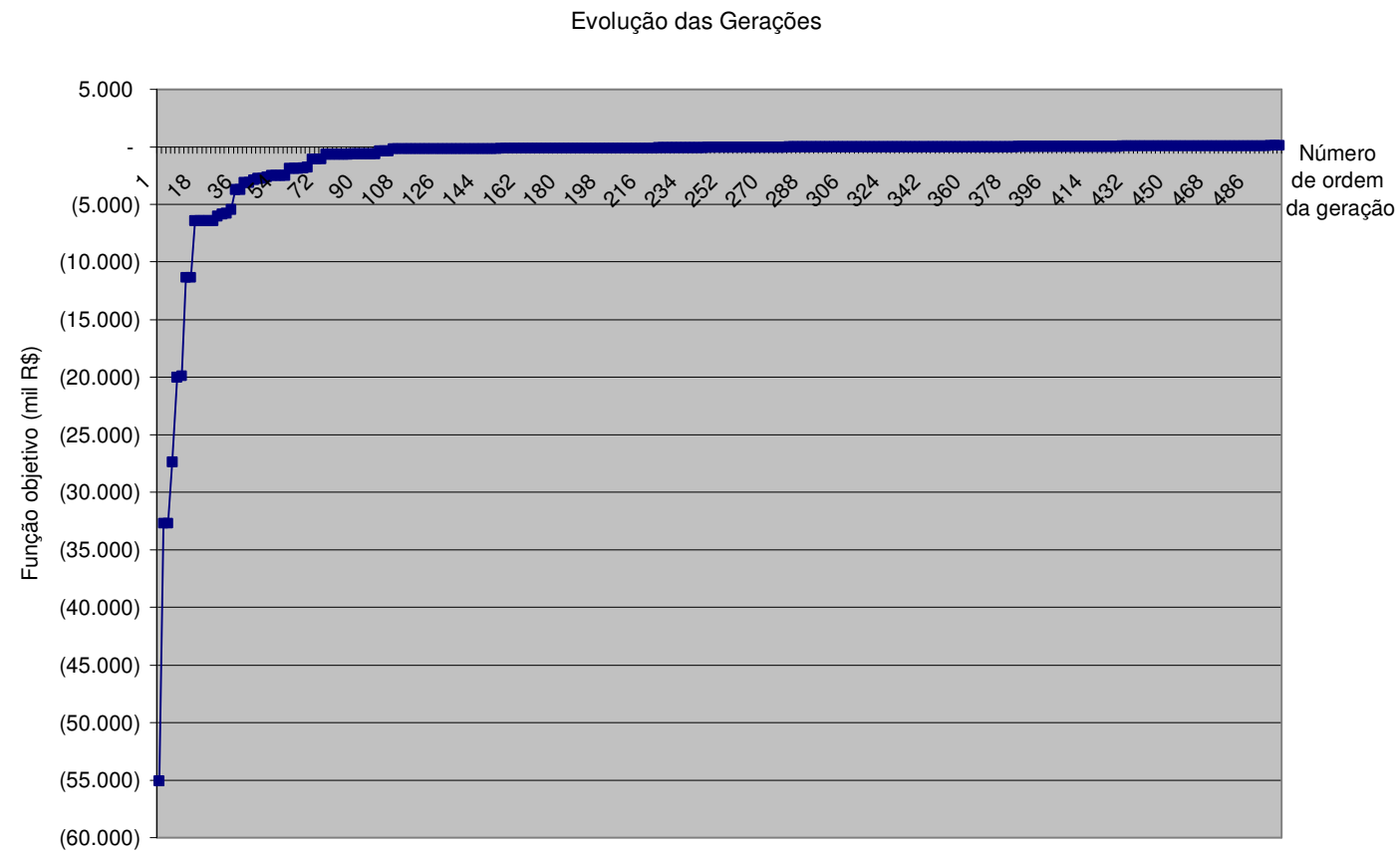

Figura 5.23 - Evolução das espécies no caso Brasil

Evolução das Gerações - Zoom nas últimas 250 Gerações

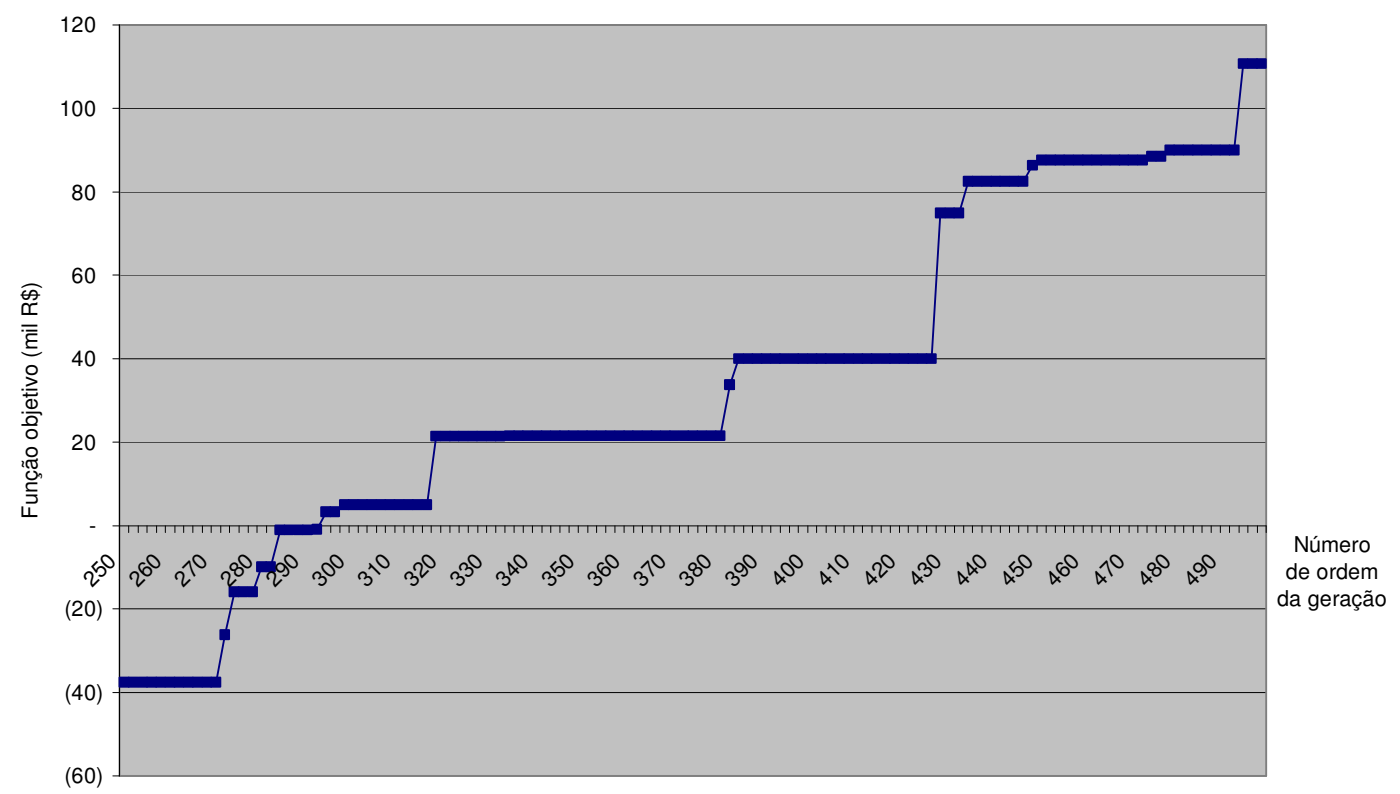

Figura 5.24 - Evolução das espécies, com zoom nas últimas 250 gerações, para o caso Brasil 
Admitindo-se, portanto, que o caso acima represente adequadamente o conjunto das Distribuidoras, pode-se passar a uma avaliação dos incentivos do Modelo e suas conseqüências sobre os diversos agentes do setor.

A primeira avaliação pretende investigar se as regras de contratação incentivam a contratação de fato da totalidade da carga das Distribuidoras.

Zoom no topo da contratação

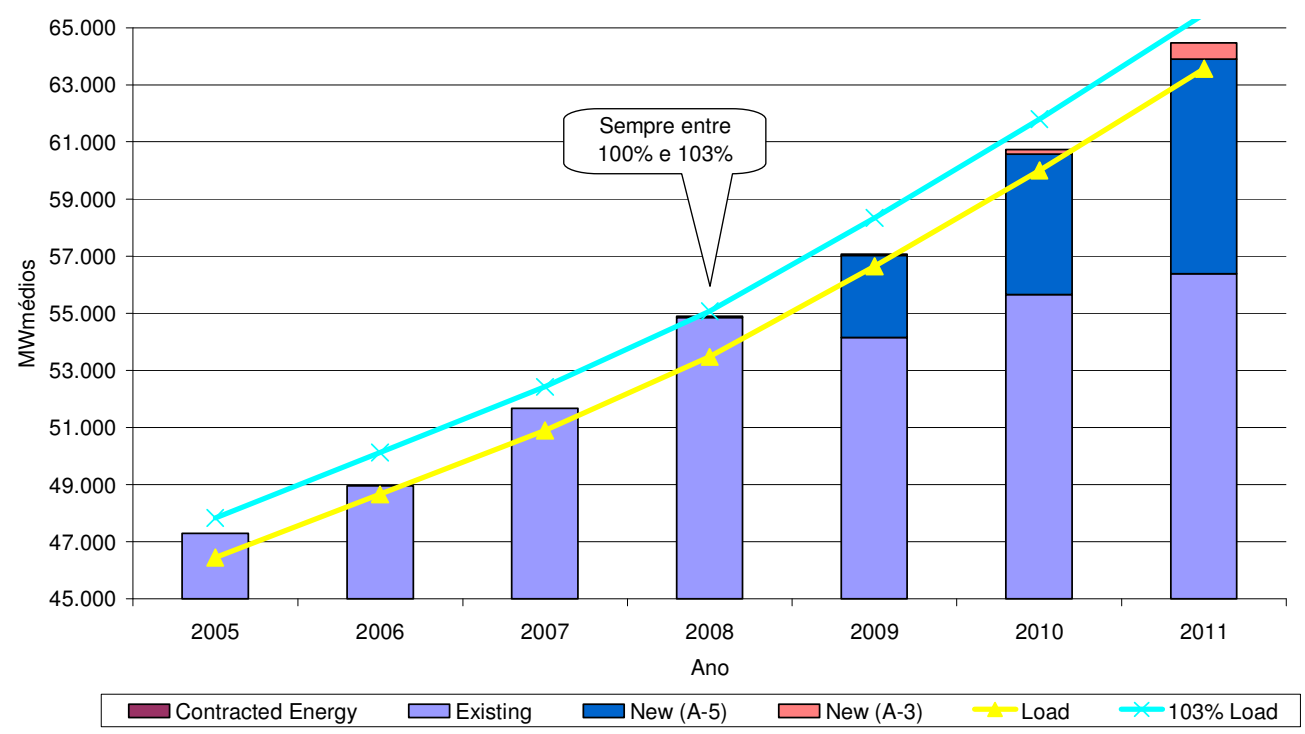

Figura 5.25 - Análise do incentivo à contratação da totalidade da carga

Como se pode observar, a contratação em todos os anos do estudo encontram-se entre $100 \%$ e $103 \%$ da carga - exatamente conforme expectativa do Governo, atendendo a premissa de Garantia de Suprimento.

Outra premissa do Modelo trata da expansão, um dos alegados principais pontos fracos do Modelo anterior. Assim, deseja-se verificar se há incentivos suficientes para contratação de energia nova com a maior antecedência possível. 
Contratação de Energia Nova (volumes em MWmédios)

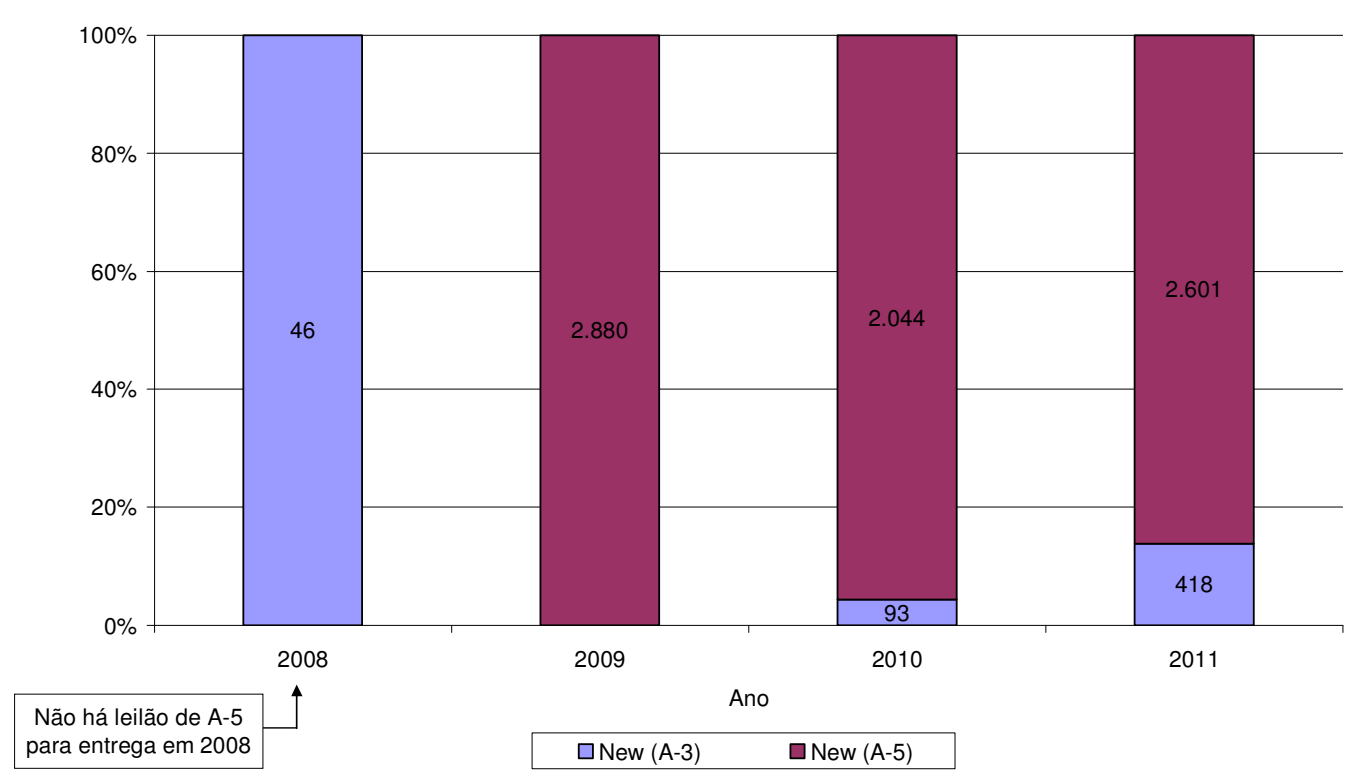

Figura 5.26 - Avaliação dos incentivos para contratação de energia nova

Como se pode observar, de fato as Distribuidoras tendem a preferir a contratação com 5 anos de antecedência (A-5), em volumes significativos, viabilizando a construção de novos empreendimentos.

Por outro lado, é possível observar o efeito da combinação da regra de incentivo à contratação de energia nova com a regra de redução dos contratos de energia existente.

Conforme se observa na Figura 5.27 (onde a linha pontilhada indica o volume de contratos de energia existente sem o exercício da opção de redução), enquanto nos primeiros anos nota-se a importância da opção de redução de volume de energia existente como ferramenta de gestão do risco de desvio de mercado pelas Distribuidoras, a partir de um dado momento - quando surge a possibilidade de compra de energia nova, com sua respectiva oportunidade de ganho na arbitragem de volumes entre A-3 e A-5 - nota-se que as Distribuidoras tendem a preferir reduzir os contratos de energia existente, comprando energia nova em seu lugar, embora houvesse demanda suficiente para que fosse utilizado na integridade o contrato de energia existente. 
Esse comportamento pode levar a um deslocamento de energia existente (supostamente mais barata) por energia nova (certamente mais cara) para os consumidores cativos. Consequientemente, haveria mais energia "velha" disponível no mercado livre, o que beneficiaria essencialmente os consumidores livres, que teriam maiores volumes de energia mais barata à sua disposição, indo possivelmente contra a premissa de Modicidade Tarifária para os consumidores cativos.

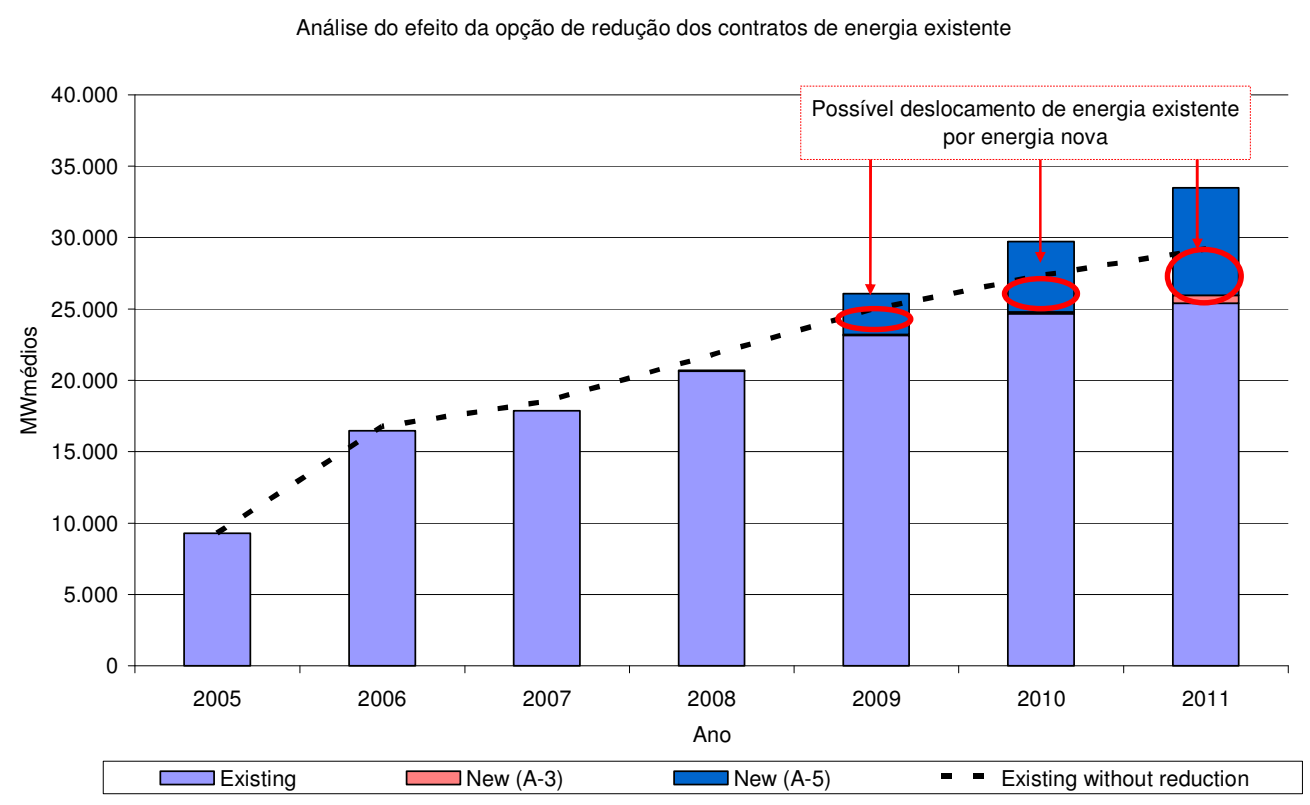

Figura 5.27 - Análise da opção de redução dos contratos de energia existente

\subsection{Alcance da análise}

O modelo de otimização de contratação desenvolvido deve simular o comportamento das Distribuidoras antes do leilão, no momento de entrega de suas declarações de necessidades de contratação ao Ministério de Minas e Energia. Desta forma, parâmetros como preços esperados devem refletir a expectativa do mercado em 
relação ao resultado dos leilões, e não como uma forma de se acompanhar durante o leilão a alteração da contratação em função das mudanças nos preços. ${ }^{18}$

A informação provida pelo modelo serve como ponto de partida para que os Geradores desenhem suas estratégias de comercialização, auxiliando na montagem de uma expectativa de balanço entre oferta e demanda. Este balanço, em conjunto com outras ferramentas (como simuladores de leilão, aplicativos para cálculo da expansão ótima do sistema e etc.) ajudam a definir uma faixa de preços esperada tanto nos negócios do Ambiente Regulado como no Ambiente Livre ${ }^{19}$.

Assim, para que se possa preparar uma estratégia adequada de atuação no mercado de energia elétrica sob o modelo em implantação, toda uma cadeia de ferramentas de apoio à decisão devem ser utilizadas, sendo o modelo aqui apresentado apenas um dos elos.

${ }^{18}$ De fato, durante os leilões as distribuidoras atuam como agentes passivos, tendo seus interesses representados pelo leiloeiro (MME) que, através de mecanismos de preços de reserva e redução de demanda, fazem o papel dinâmico do comprador, à revelia destes.

${ }^{19}$ Apesar de os preços do Ambiente Livre serem, como o nome sugere, livremente negociados entre as partes, espera-se que os preços resultantes dos leilões no Ambiente Regulado sirvam como uma sinalização da curva de preço do mercado. 


\section{CONCLUSÕES E RECOMENDAÇÕES}

A pesquisa e os estudos realizados apontam para algumas conclusões, que podem ser divididas em aquelas relativas ao Modelo Institucional e as relativas ao otimizador desenvolvido.

\subsection{Com relação ao Modelo Institucional do Setor Elétrico}

Uma das premissas do Modelo, que é a garantia de suprimento, operacionalizada através de incentivos e penalizações e observada através da indicação da contratação a ser seguida, foi atendida - de fato, os resultados apresentados pelo otimizador indicam contratação acima do mercado esperado.

Também é possível notar que as regras de incentivo à contratação de energia nova com a maior antecedência possível e em volumes significativos, de forma a viabilizar a expansão do sistema, foram eficazes.

Todavia, essa regra, em conjunto com a possibilidade de redução dos contratos de energia existente, pode levar a um deslocamento de energia "velha" (supostamente mais barata) por energia nova (mais cara), penalizando os consumidores cativos em detrimento dos consumidores livres, que terão maior volume de energia existente à sua disposição no ACL.

Ainda, há de se apontar que os instrumentos de mitigação de risco para as distribuidoras - diversos leilões para contratação de energia, possibilidade de redução dos contratos de energia existente, regras de repasse para as tarifas dos consumidores - parecem ser adequados ${ }^{20}$.

\footnotetext{
${ }^{20}$ É de se esperar que concessionários detentores de monopólio natural como a distribuição de energia elétrica ao consumidor final sejam agentes aversos ao risco, dando maior segurança aos seus consumidores cativos.
} 


\subsection{Com relação ao modelo de otimização desenvolvido}

Com relação ao otimizador, observou-se que a utilização de binário Gray ao invés do convencional melhorou o desempenho do algoritmo, atingindo resultados melhores com menor número de gerações. Também é possível afirmar que a discretização dos valores pareceu adequada - margem de erro compatível com ordem de grandeza dos volumes.

Finalmente, a redução do horizonte de estudo, além de permitir maior segurança ao usuário na definição dos dados de entrada e maior confiança nos resultados, possibilitou ganho de memória e tempo de processamento.

\subsection{Futuras extensões}

Se por um lado os agentes Distribuidores têm alguns mecanismos de mitigação de seus riscos, como os diversos leilões de compra e a possibilidade de redução dos contratos de energia existente, por outro lado, pode-se questionar se parcela significativa dos riscos não teria sido alocada aos agentes Geradores, especialmente àqueles detentores de energia existente. Uma investigação desta distribuição de riscos no setor elétrico parece merecer atenção, já que uma alocação desigual pode ter conseqüências importantes no desempenho econômico-financeiro dos Agentes, podendo ameaçar a estabilidade do setor.

Ademais, poder-se-ia avaliar as conseqüências nos processos de liquidação e contabilização da CCEE causadas pelos incentivos à sobrecontratação das distribuidoras. Em outras palavras, poder-se-ia estudar quais os possíveis impactos no mercado de curto prazo decorrentes dos incentivados aos agentes à contratação de energia acima de seus consumos verificados.

Em relação ao desenvolvimento do modelo de otimização, poder-se-ia buscar um maior detalhamento na modelagem do problema, de forma a incorporar variáveis probabilísticas como cenários de crescimento de mercado e curvas de preço spot, 
tornando seu uso de interesse tanto pelos agentes vendedores como pelas próprias Distribuidoras.

Eventualmente, poder-se-iam incluir outras variáveis de decisão, como a possibilidade de incentivo pela Distribuidora para que consumidores potencialmente livres localizados em sua área de concessão optem pelo Ambiente de Contratação Livre (ACL), reduzindo a carga própria da distribuidora e gerando a opção de redução dos contratos de energia existente, gerando mais uma ferramenta de gestão de riscos. 


\section{REFERÊNCIAS BIBLIOGRÁFICAS}

ANEEL - Agência Nacional de Energia Elétrica (2004). Apresenta dados regulatório do Setor Elétrico Brasileiro. Disponível em http://www.aneel.gov.br. Acesso em 1 de setembro de 2004 .

ANEEL - Agência Nacional de Energia Elétrica (2005). Cadernos Temáticos ANEEL - Energia Assegurada. Brasília: ANEEL, 2005

Ávila, S.L., Lima, C.B., Carpes Júnior, W.P. e Vasconcelos, J.A. (2003). Otimização - Conceitos Básicos, Ferramentas e Aplicações. Revista de Automação e Tecnologia da Informação, CTAI-SENAI, Florianópolis, Jan/Jun, vol. 2, n.1, pg. 70-75, 2003.

Barcellos, J.C.H. (2000). Algoritmos Genéticos Adaptativos: Um estudo comparativo. São Paulo: Escola Politécnica da Universidade de São Paulo, $\mathrm{abr} / 2000$.

Bento, E.P. (2004). Algoritmos genéticos e suas variantes na solução de problemas de minimização de perdas em redes de distribuição. São Paulo: Escola Politécnica da Universidade de São Paulo, 2004.

Borges, L.F.X e Faria, V.C.S. (2002). Project Finance: Considerações sobre a Aplicação em Infra-Estrutura no Brasil. Revista do BNDES, n. 18, v. 9, p. 241$280, \mathrm{dez} / 2002$.

Comitê de Revitalização do Modelo do Setor Elétrico (2002a). Relatório de $\begin{array}{lllll}\text { Progresso } & \mathrm{n}^{\mathrm{O}} & 1 . & \text { Disponível }\end{array}$ http://www.energiabrasil.gov.br/estudos_pesquisas/i_090102.ppt. Acesso em 23 de junho de 2004. 
Comitê de Revitalização do Modelo do Setor Elétrico (2002b). Relatório de $\begin{array}{lllll}\text { Progresso } & \mathrm{n}^{\mathrm{o}} & 2 . & \text { Disponível }\end{array}$ http://www.energiabrasil.gov.br/docs/rel_progress_2.pdf. Acesso em 23 de junho de 2004.

COPEL (2004). Boletim RI Informe 20 - Contratos de Energia da COPEL. Disponível em http://www.copel.com/pagcopel.nsf/arquivos/bri20_04port/\$FILE/BRI20_04port. pdf. Acesso em 17 de janeiro de 2005.

Dornellas, C.R.R. (1997). Otimização do Despacho de Reativos Utilizando Algoritmos Genéticos. Rio de Janeiro: Universidade Federal do Rio de Janeiro, COPPE, nov/1997.

Dornellas, C.R.R. e Sant'Anna, L.A.F.P. (2004). Os Efeitos Positivos do Entendimento do Mercado Contemporâneo de Energia Elétrica Sobre a Gestão Estratégica da Duke Energy. Belo Horizonte: Fundação Dom Cabral, 2004.

Energia Brasil (2002). Site sob responsabilidade da extinta Câmara de Gestão da Crise de Energia Elétrica (GCE). Disponível em http://www.energiabrasil.gov.br. Acesso em 23 de junho de 2004.

Galvão Júnior, F.A. (2004). Otimização do sistema de coleta de resíduos de biomassa de madeira para fins energéticos. São Paulo: Escola Politécnica da Universidade de São Paulo, 2004.

Instituto Cidadania (2002). Diretrizes e linhas de ação para o Setor Elétrico Brasileiro. Disponível em http://www.lula.org.br/assets/projeto_energia_eletrica.pdf. Acesso em 23 de junho de 2004. 
Kagan, N. e Oliveira, C.C.B. (2003). Configuração de Redes de Distribuição Através de Algoritmos Genéticos. Notas de aula da disciplina PEA 2522 - Técnicas de Otimização em Engenharia de Potência. São Paulo, 2003.

MME (2003a). Proposta de Modelo Institucional do Setor Elétrico. Brasília, jul/2003.

MME (2003b). Proposta de Modelo Institucional do Setor Elétrico. Brasília, $17 / \mathrm{dez} / 2003$.

MME (2004). Nota à imprensa. Brasília, 30/jul/2004.

ONS (2005). RE 3/237/2005 - Planejamento Anual da Operação Energética - 2005 Sumário Executivo. Rio de Janeiro: Operador Nacional do Sistema Elétrico, 2005.

Ramos, D.S. (2004). Notas de aula da disciplina PEA 5771 - Formação de Preços e Comercialização de Energia no Novo Ambiente do Setor Elétrico. São Paulo, 2004.

Ramos, D.S.R, Fadigas, E.A.A. e Lima, W.S. (2000). Novo Ambiente Regulatório Brasileiro, Regras de Mercado e Condicionantes para Geradores Termelétricos. São Paulo: Petrobras/FUSP, 2000.

Risso, G. (2002). Sintonia de controladores PID por algoritmos genéticos. São Paulo: Escola Politécnica da Universidade de São Paulo, 2002.

Sauer, I. (2002). Um Novo Modelo para o Setor Elétrico Brasileiro. São Paulo: Instituto de Eletrotécnica e Energia da USP, dez/2002.

Soares, G.L. (1997). Algoritmos Genéticos: Estudo, Novas Técnicas e Aplicações. Belo Horizonte: Universidade Federal de Minas Gerais, 1997. 
Umbria, F. (2001). Modelo de previsão de preços futuros de energia. In: Seminário de Planejamento Econômico-Financeiro do Setor Elétrico, 9, 2001. Ipojuca: Companhia Hidro Elétrica do São Francisco, 2001. 